\title{
دوافع تعرض المرأة لأفلام \\ الرعب والإشباعات المتحققة منها
}

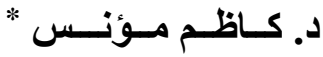

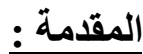

لاتتفصل الفنون وبالذات السينما عن الواقع والحياة الاجتماعية فلطالما كانت الحياة

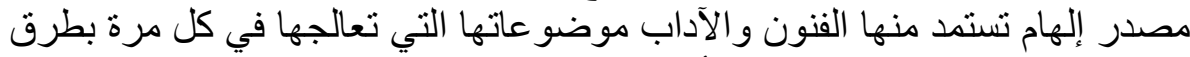

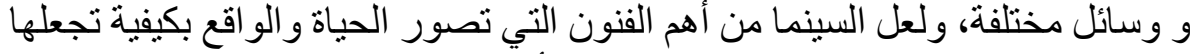

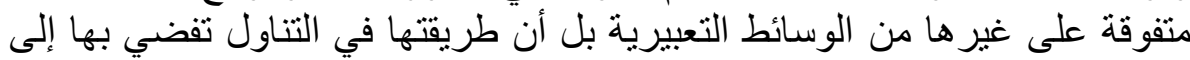

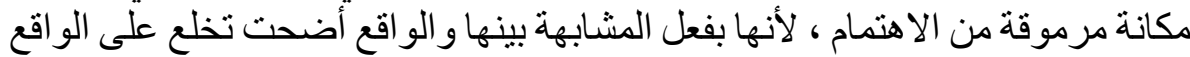

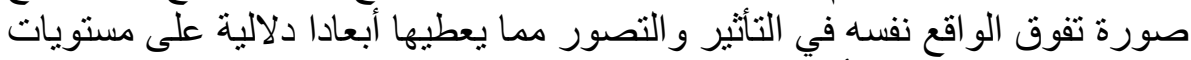

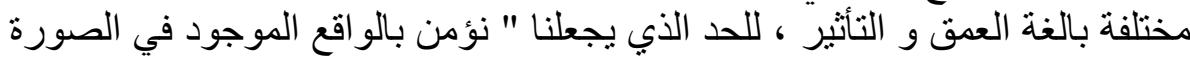

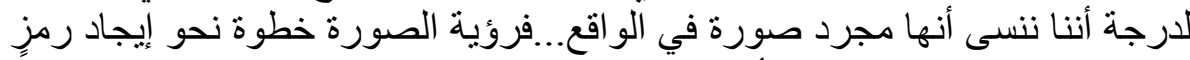

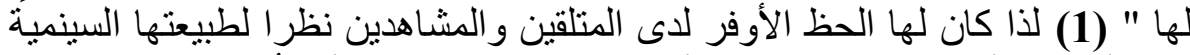

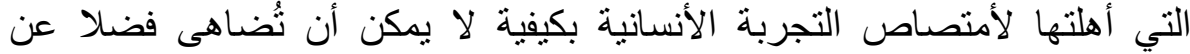

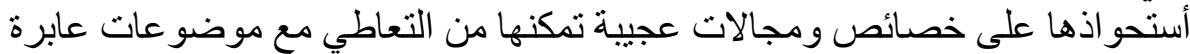

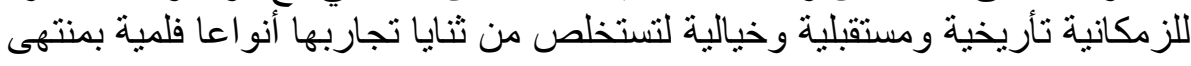

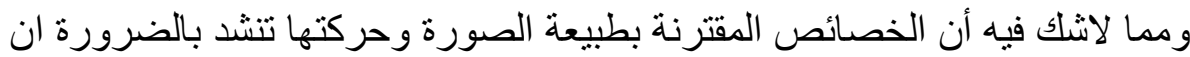

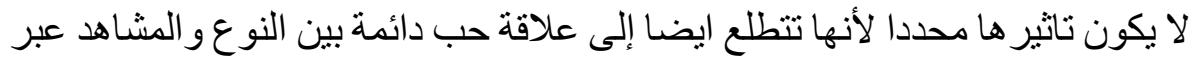

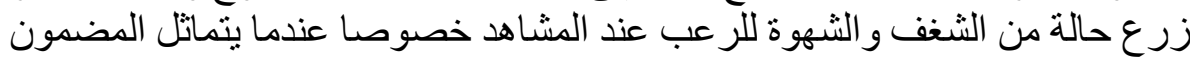

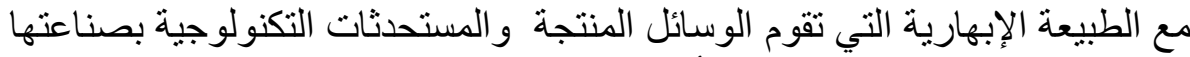

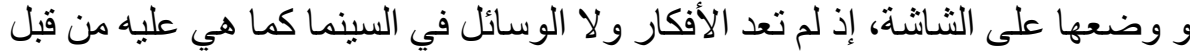

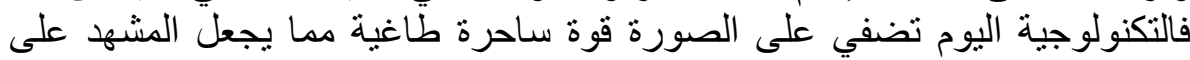

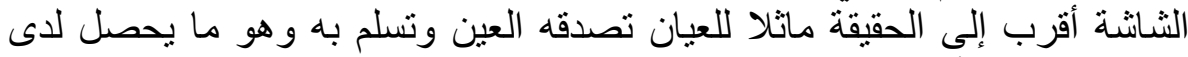

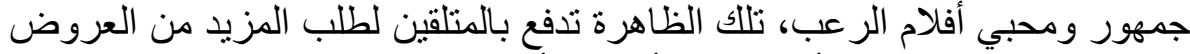

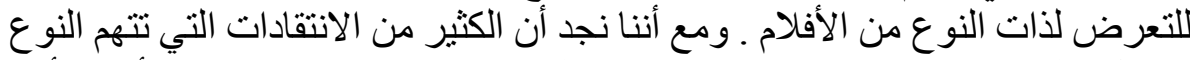

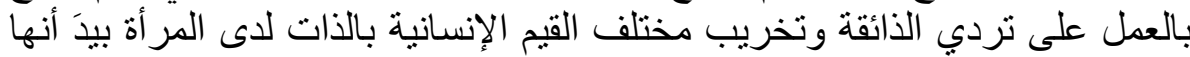

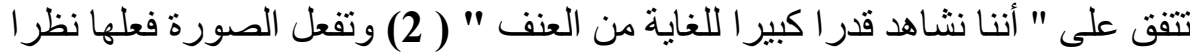
لما فيها من قوة ذات طاقة تأثيرية عالية المستوى تدفع المتلقي إلى أعماقها السحيقة الماتية

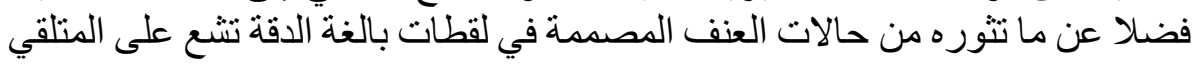

* الجـامعة الأهليـة ـ مهلكـــة البحريـن 


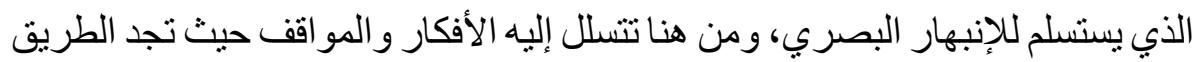

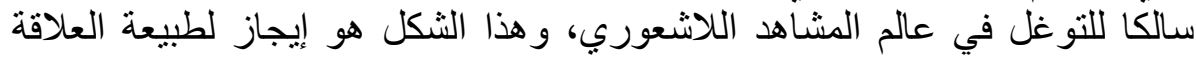
المتر ابطة بين المتلقي وما يتعرض الئر إليه.

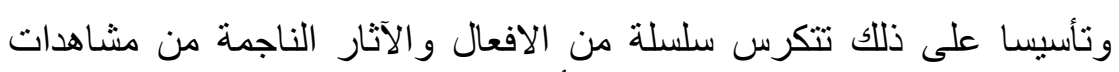

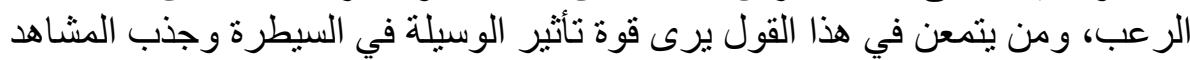

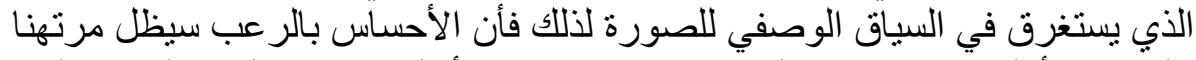

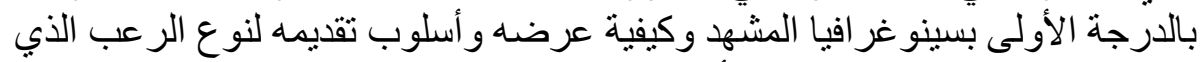

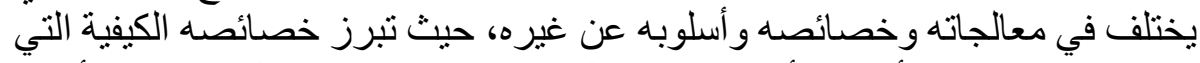

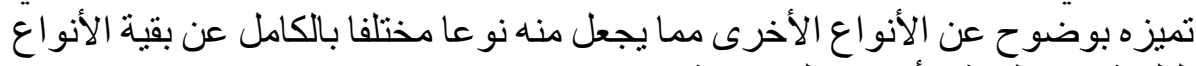
الفلمية في نظرية الأجناس السينمائية.

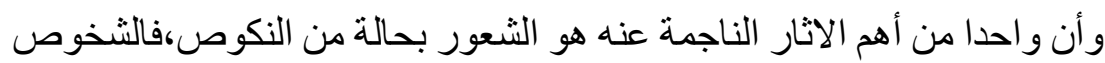

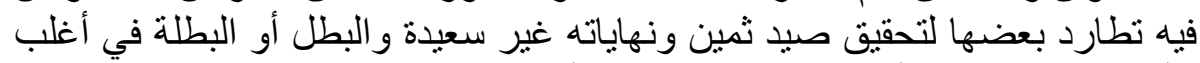

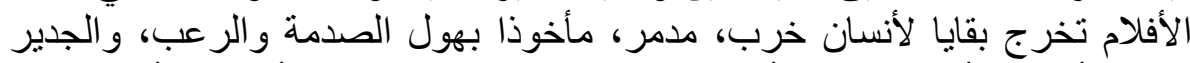

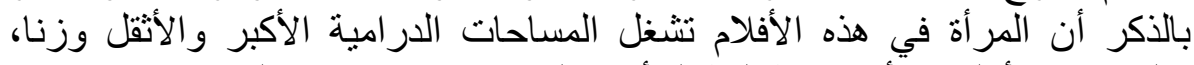

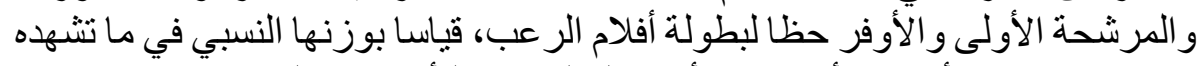

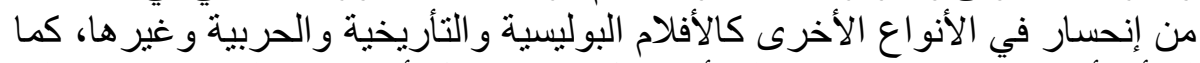

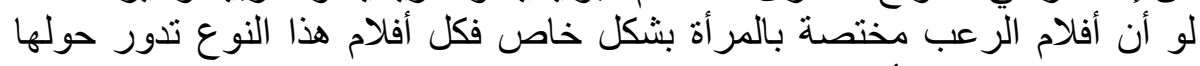

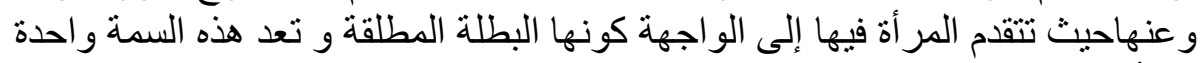

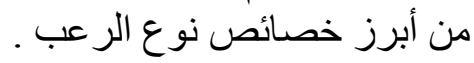

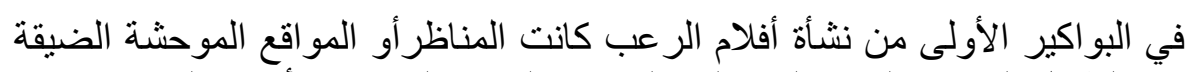

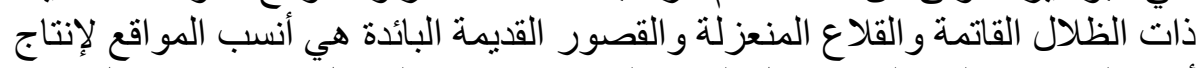

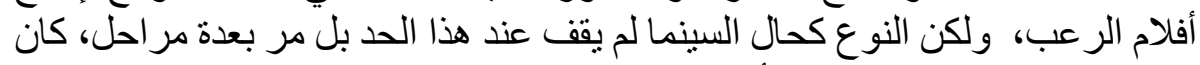

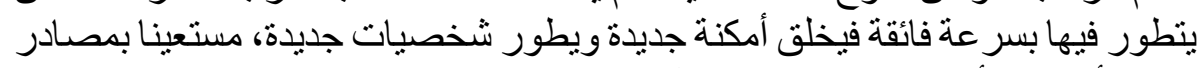

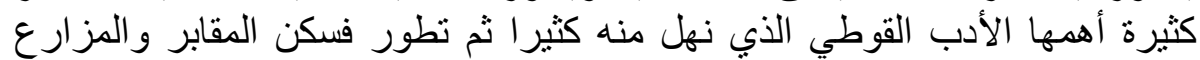

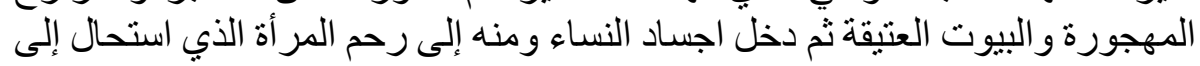

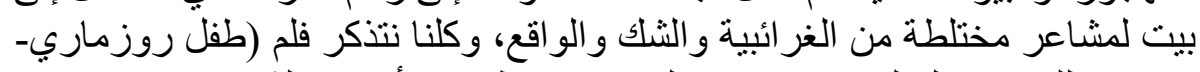

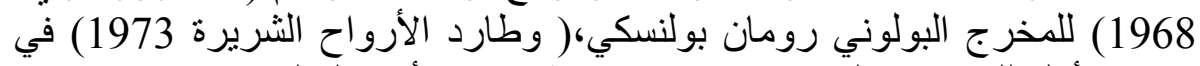

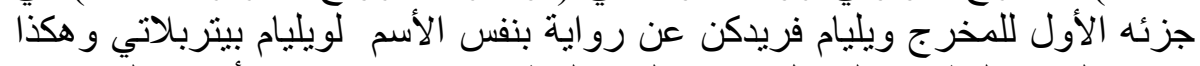

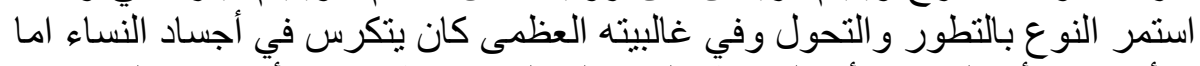

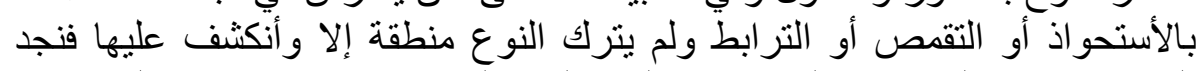

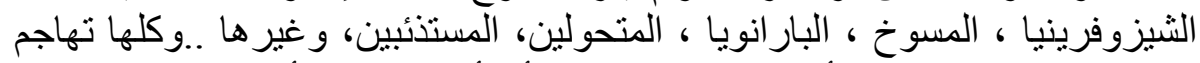

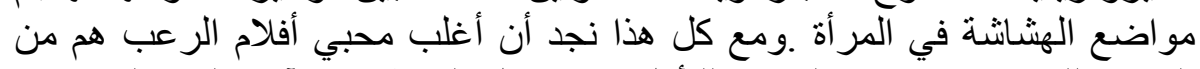

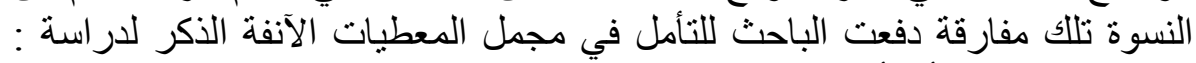
دو افع تعرض المر أة لأفلام الرعب دالب والإشباعات المتحققة منها.. 
مشكلة الار اسة :-

نوع الرعب هو واحد من هذه الأنواع التي حظيت باهتمام بالغ ومتز ايد في العقدين

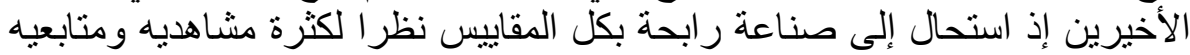

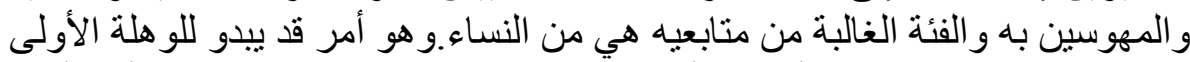

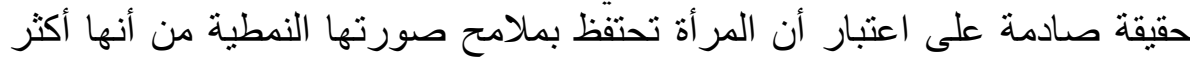

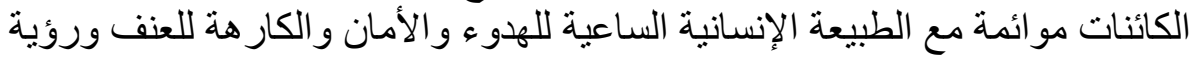

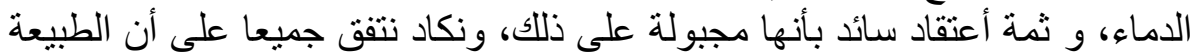

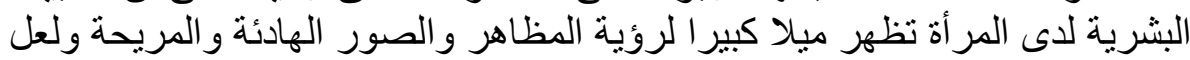

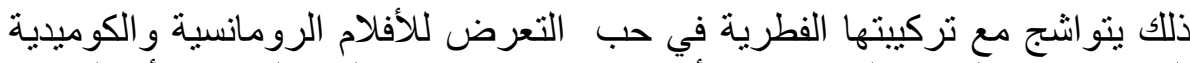

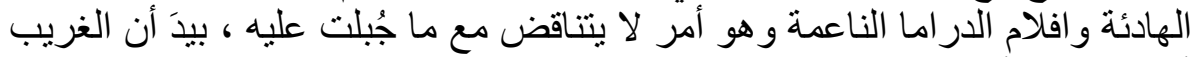

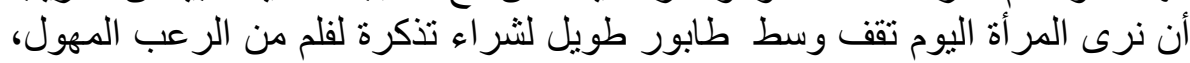

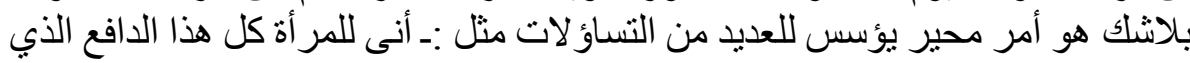

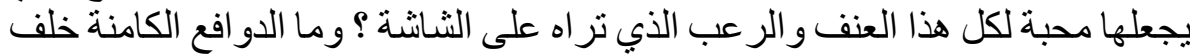

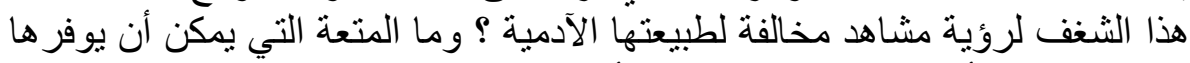

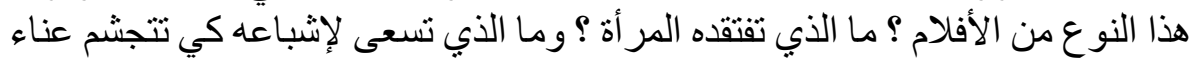

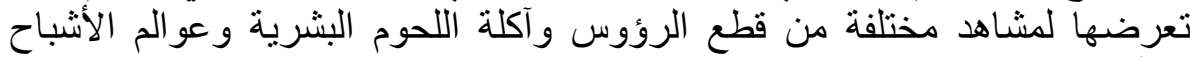

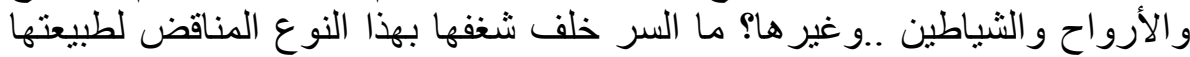

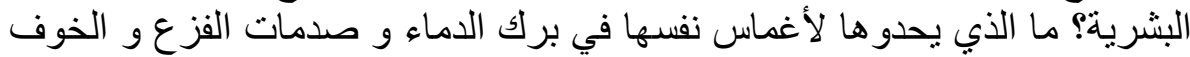

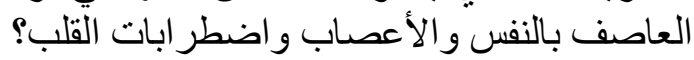

من المؤكد أن ثمة أجوبة عديدة مفترضة تنتجها هذه التساؤلات تتقدمها بشكل مباشر

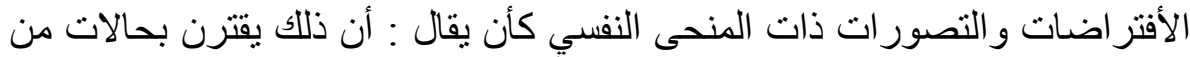

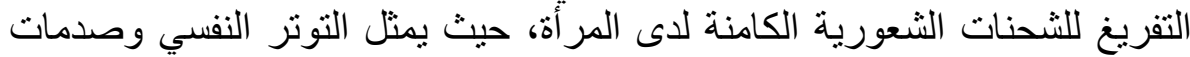

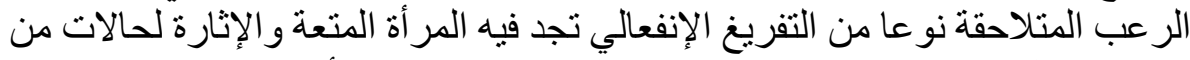

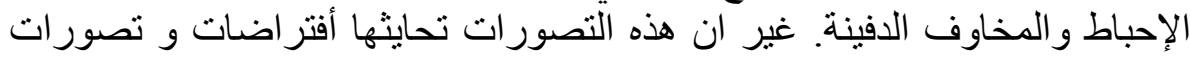

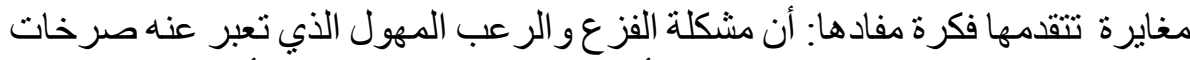

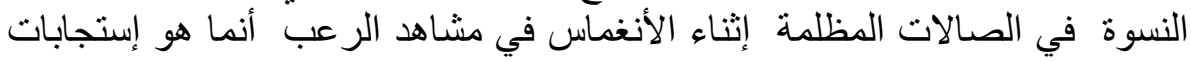

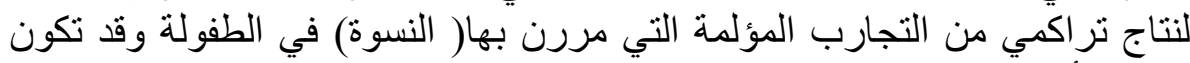

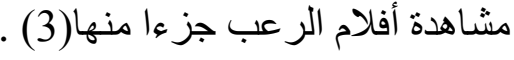

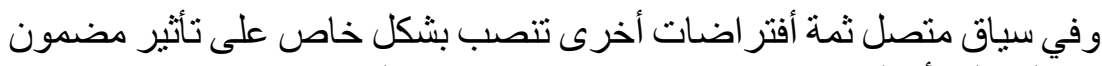

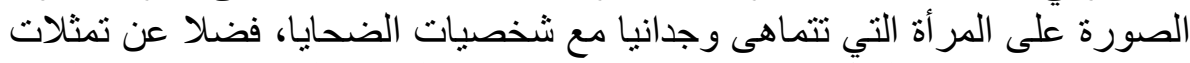

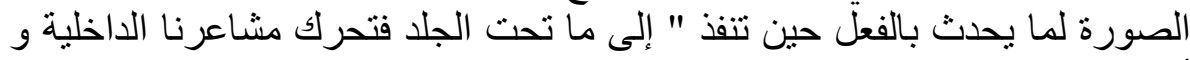

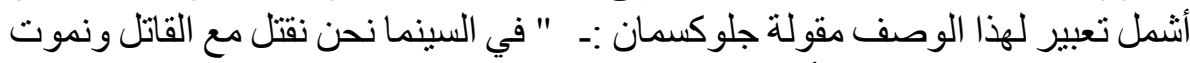

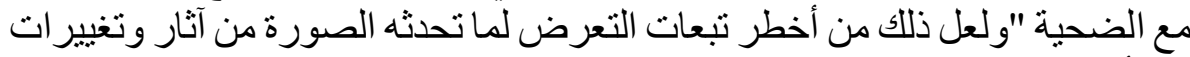

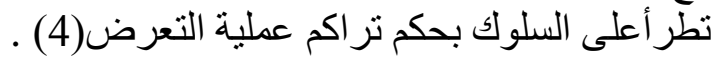




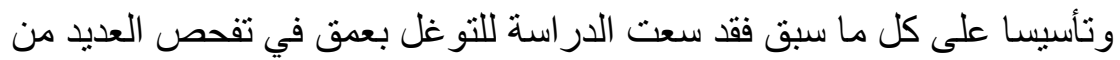

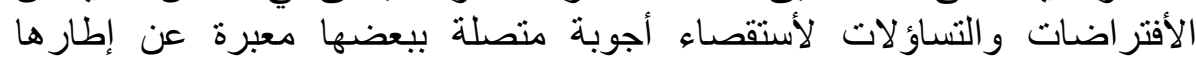

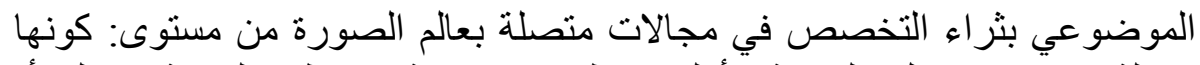

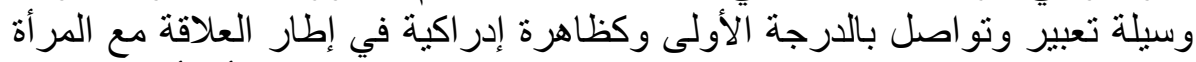

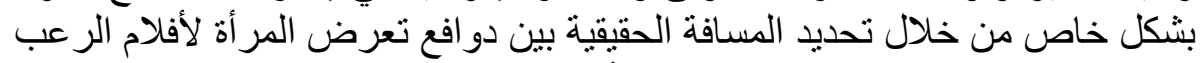

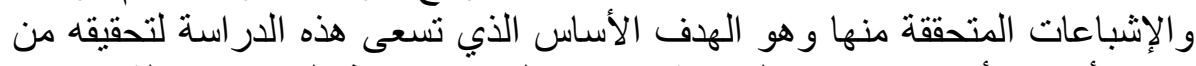

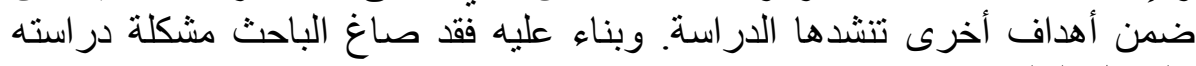

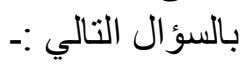

ما الدوافع الكامنة خلف تعرض المرأة لأفلام الرعب وما الإثباعات المتحققة منها ؟

$$
\begin{aligned}
& \text { أهداف الدراسة :- مالد الكامنه } \\
& \text { تهدف الدراسة إلى التعرف على اله ما يلي :- }
\end{aligned}
$$

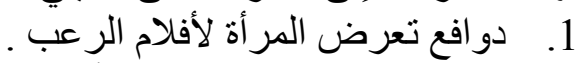

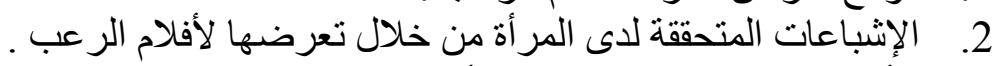

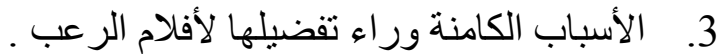

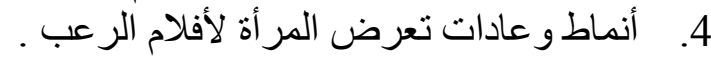

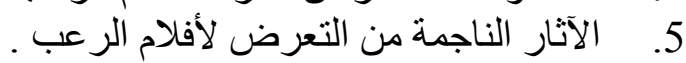

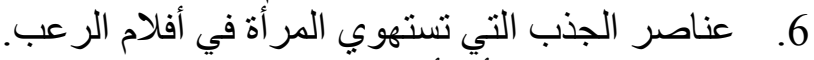

$$
\begin{aligned}
& \text { 7. }
\end{aligned}
$$

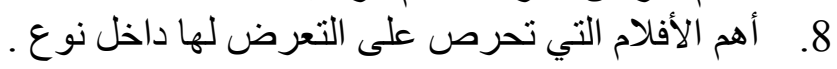

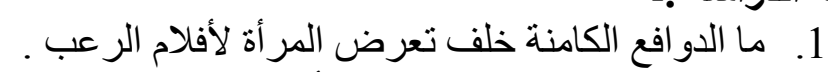

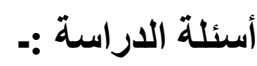

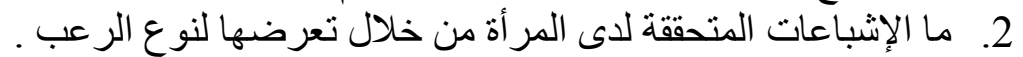

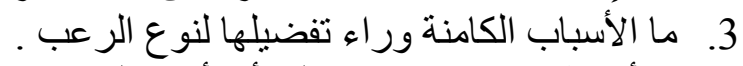

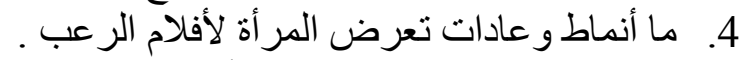

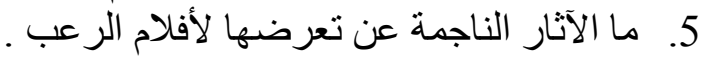

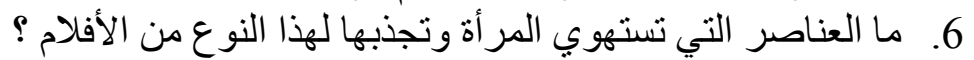

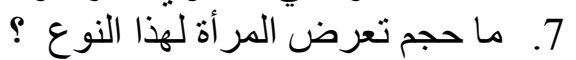

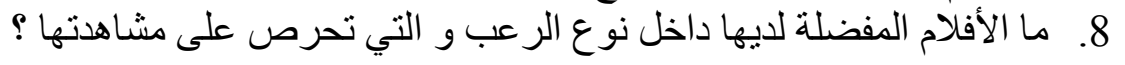

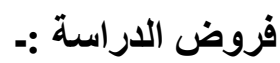

$$
\begin{aligned}
& 1 \text { ـ لا توجد علاقة ارتباطية دالة إحصائيا بين دو افع تعرض المر أة لأفلام الرعب . }
\end{aligned}
$$

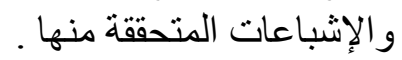

$$
\begin{aligned}
& \text { 2. لا توجد علاقة ارتباطية دالة إحصائيا بين دو افع تعرض لأفلام الر عب و الآثار } \\
& \text { الناجمة عنها. }
\end{aligned}
$$


1. الحدود الموضو عية: وتتمثل بدو افع تعرض المر أة لأفلام الرعب و الإشباعات

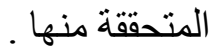

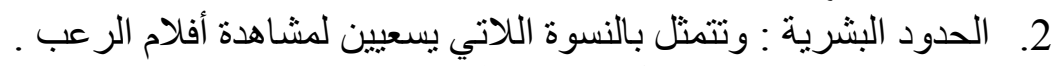

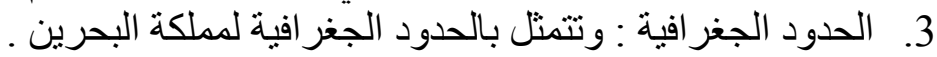

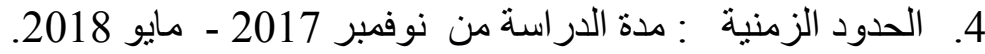

$$
\text { نوع الاراسة :- }
$$

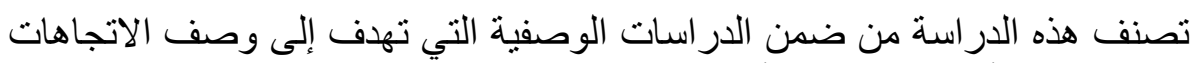

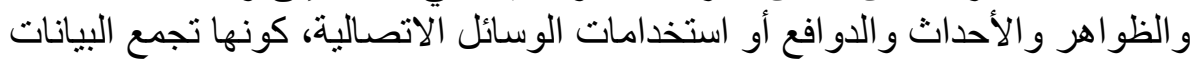

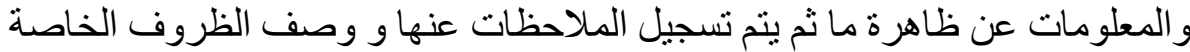

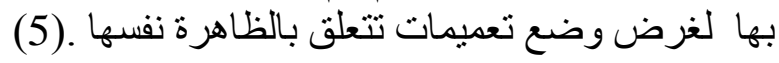

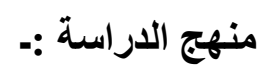

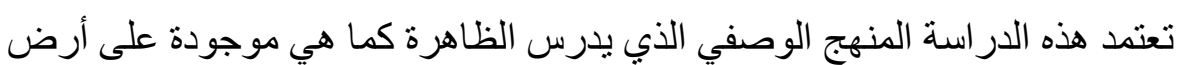

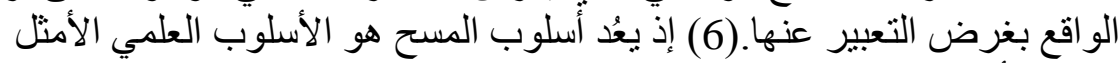
لملائمة أهداف الدر اسة الحالية وتطلعات الباحث.

$$
\text { مجتمع الاراسة: }
$$

يعرف مجتمع الدر اسة "بأنه جميع افر اد الظاهرة المقصود در استها" ( 7 ) ) وتأسيسا على ذلك فأن مجتمع الدر اسة الحالية يتمثل بجميع النسوة اللاتي يتعرضن لأنس لأفلام

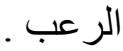

$$
\text { عينة الدراسة :- أب }
$$

و هي "مفردات أختيرت بعناية فائقة وفقا لمعايير محددة تحقق التمانل في خصــائصـهـا

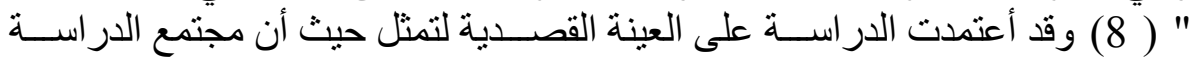

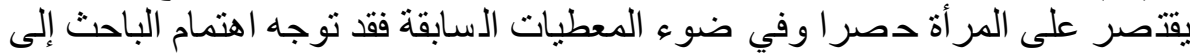

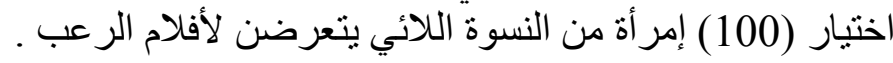

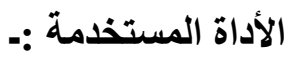

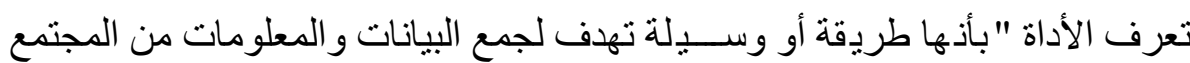

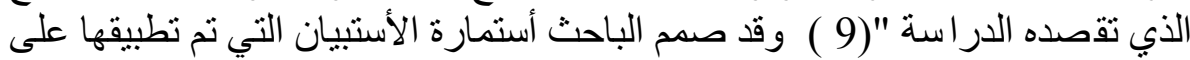

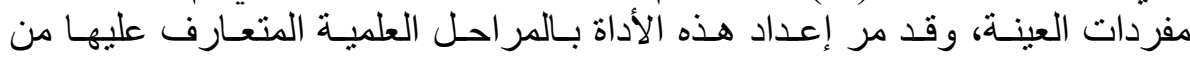

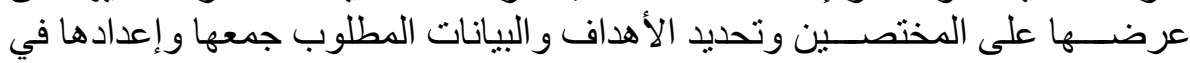
صورتها الأولية ومر اجعتها منهجيا و وعليا. 


\section{مؤشرات صدق وثبات المقياس أولاً: صدق صحيفة الأستبيان}

للتحقق من صدق القياس قام الباحث بعرض الأستمارة على مجموعة من الإن المحكمين

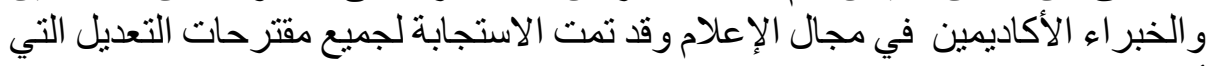

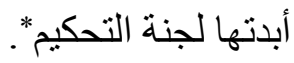

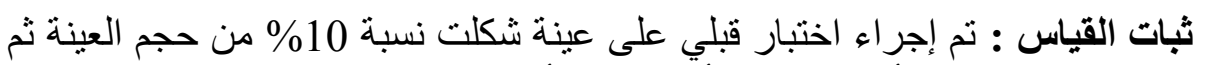

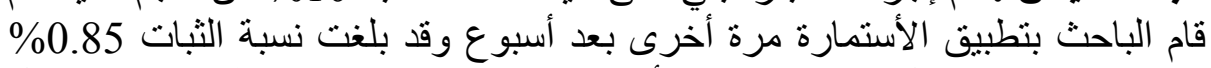

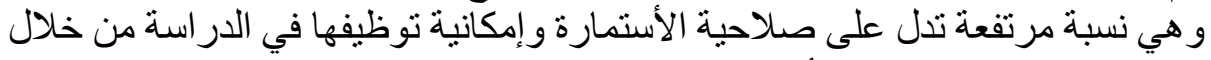

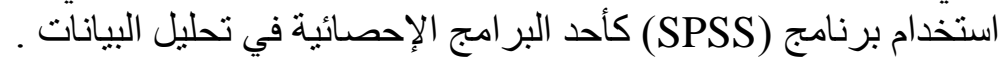

$$
\text { ثانياً: صدق الاتساق الداخلي }
$$

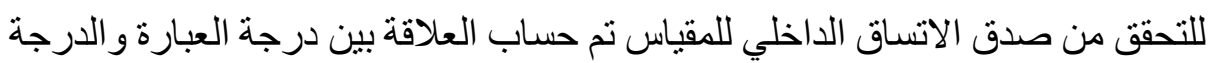

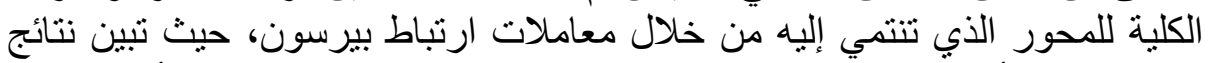

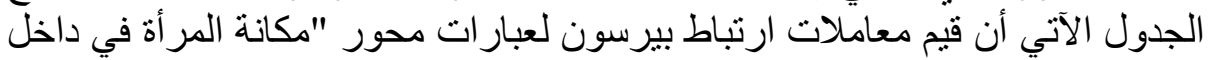

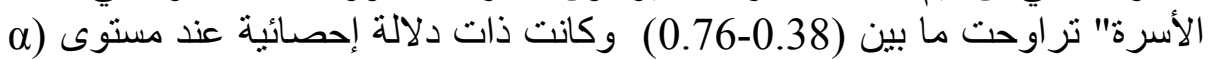

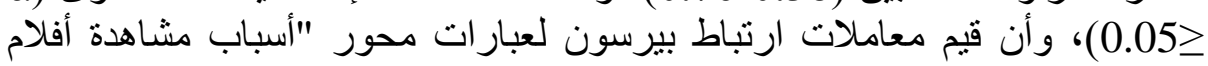

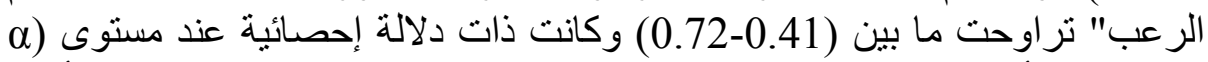

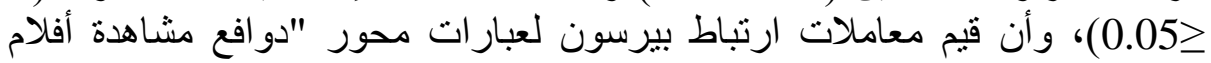

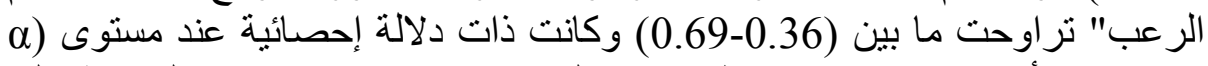

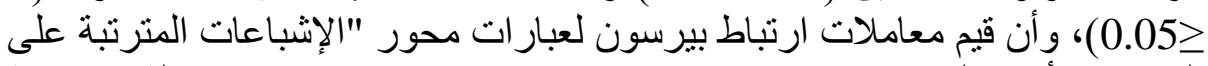

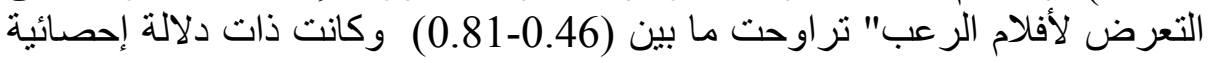

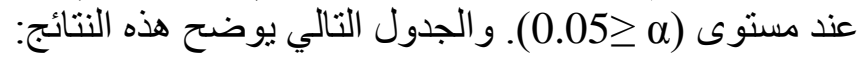

1. الدكتور عبد الصادق حسن أستاذ الأعلام المشارك بالجامعة الأهلية بمملكة البحرين. 2.

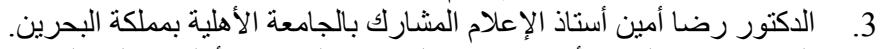
4. الدكتور حسام إلهامي أستاذ الإعلام المساعد بالجامعة بالجامة الأهلية بمملكة البحرين. 


\section{جدول رقم (1) مؤشرات صدق الاتساق الاخلي لأداة الدراسة}

\begin{tabular}{|c|c|c|c|c|c|c|c|}
\hline \multicolumn{2}{|c|}{ المترتبة على الإشباعات التعرض الأفلام الرعب } & \multicolumn{2}{|c|}{ محور دوافع مشـاهدة } & \multicolumn{2}{|c|}{ محور أسباب مشاهدة أربام } & \multicolumn{2}{|c|}{ محور مكانة المر أة في } \\
\hline معامل ارتباط بيرسون & الرقم & معامل ارتباط بيرسون & الرقم & معامل ارتباط بيرسون & الرقم & معامل ارتباط بيزسون & الرقم \\
\hline $.66(* *)$ & 1 & $.65(* *)$ & 1 & $.68(* *)$ & 1 & $.38(*)$ & 1 \\
\hline $.63(* *)$ & 2 & $.64(* *)$ & 2 & $.57(* *)$ & 2 & $.41(*)$ & 2 \\
\hline $.49(* *)$ & 3 & $.62(* *)$ & 3 & $.41(*)$ & 3 & $.53(* *)$ & 3 \\
\hline $.70(* *)$ & 4 & $.43\left(^{*}\right)$ & 4 & $.64(* *)$ & 4 & $.69(* *)$ & 4 \\
\hline $.78(* *)$ & 5 & $.36(*)$ & 5 & $.49(* *)$ & 5 & $.52(* *)$ & 5 \\
\hline $.56(* *)$ & 6 & $.48(* *)$ & 6 & $.45(*)$ & 6 & $.48(* *)$ & 6 \\
\hline $.46\left(^{*}\right)$ & 7 & $.58(* *)$ & 7 & $.54(* *)$ & 7 & $.57(* *)$ & 7 \\
\hline $.64(* *)$ & 8 & $.64(* *)$ & 8 & $.52(* *)$ & 8 & $.66(* *)$ & 8 \\
\hline $.57(* *)$ & 9 & $.56(* *)$ & 9 & $.61(* *)$ & 9 & $.62(* *)$ & 9 \\
\hline $.50(* *)$ & 10 & $.52(* *)$ & 10 & $.48(* *)$ & 10 & $.68(* *)$ & 10 \\
\hline $.58(* *)$ & 11 & $.54(* *)$ & 11 & $.66(* *)$ & 11 & $.65(* *)$ & 11 \\
\hline $.61(* *)$ & 12 & $.66(* *)$ & 12 & $.68(* *)$ & 12 & $.76(* *)$ & 12 \\
\hline $.57(* *)$ & 13 & $.49(* *)$ & 13 & $.72(* *)$ & 13 & $.74(* *)$ & 13 \\
\hline $.76(* *)$ & 14 & $.39(*)$ & 14 & $.58(* *)$ & 14 & $.72(* *)$ & 14 \\
\hline $.81(* *)$ & 15 & $.42(*)$ & 15 & $.64(* *)$ & 15 & $.70(* *)$ & 15 \\
\hline $.58(* *)$ & 16 & $.51(* *)$ & 16 & $.48(* *)$ & 16 & $.52(* *)$ & 16 \\
\hline $.60(* *)$ & 17 & $.67(* *)$ & 17 & $.59(* *)$ & 17 & & \\
\hline $.79(* *)$ & 18 & $.59(* *)$ & 18 & $.50(* *)$ & 18 & & \\
\hline $.76(* *)$ & 19 & $.65(* *)$ & 19 & $.62(* *)$ & 19 & & \\
\hline $.53(* *)$ & 20 & $.57(* *)$ & 20 & $.46(*)$ & 20 & & \\
\hline $.49(* *)$ & 21 & $.54(* *)$ & 21 & $.67(* *)$ & 21 & & \\
\hline $.52(* *)$ & 22 & $.53(* *)$ & 22 & $.56(* *)$ & 22 & & \\
\hline $.56(* *)$ & 23 & $.49(* *)$ & 23 & $.61(* *)$ & 23 & & \\
\hline $.49(* *)$ & 24 & $.62(* *)$ & 24 & $.53(* *)$ & 24 & & \\
\hline $.51(* *)$ & 25 & $.68(* *)$ & 25 & $.54(* *)$ & 25 & & \\
\hline $.48(* *)$ & 26 & $.45(*)$ & 26 & & & & \\
\hline $.55(* *)$ & 27 & $.63(* *)$ & 27 & & & & \\
\hline & & $.43(*)$ & 28 & & & & \\
\hline & & $.42(*)$ & 29 & & & & \\
\hline & & $.68(* *)$ & 30 & & & & \\
\hline & & $.63(* *)$ & 31 & & & & \\
\hline & & $.38(*)$ & 32 & & & & \\
\hline & & $.39(*)$ & 33 & & & & \\
\hline & & $.67(* *)$ & 34 & & & & \\
\hline
\end{tabular}

* الارتباط دال إحصائيا عند (0.05 (0.05).

*** الارتباط دال إحصائيا عند (0.01 (0.01). 
ثالثاً: ثبات الاتساق الاخلي للمقياس قام الباحث بحساب مؤشر ات ثبات الاتساق الأخلي للمقياس من خلال معادلة الألة كرونباخ-

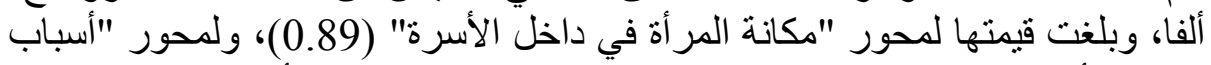

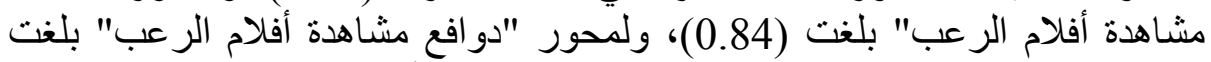

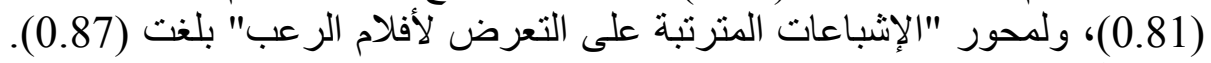
و الجدول التالي يوضح هذه النتائج:

\begin{tabular}{|c|c|c|}
\hline معامل ارتباط بيرسون & 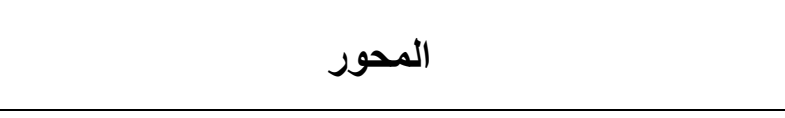 & الرقم \\
\hline 0.89 & محور مكانة المر أة في داخل الأسرة & 1 \\
\hline 0.84 & محور أسباب مشاهدة أفلام الرعب & 2 \\
\hline 0.81 & محور دو افع مشـاهدة أفلام الرعب & 3 \\
\hline 0.87 & محور الإشباعات المترتبة على التعرض لأفلام الر عب & 4 \\
\hline
\end{tabular}

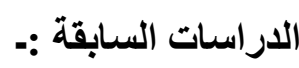

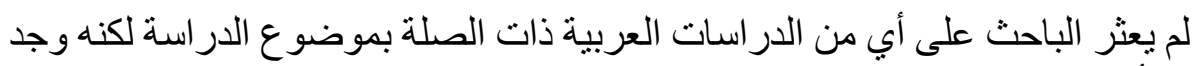

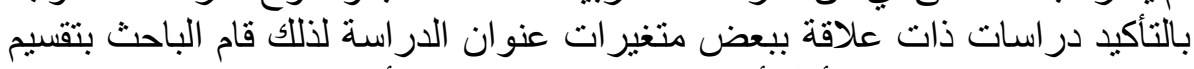

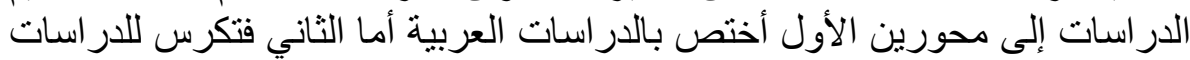
الأجنبية :- الأبات

محور الارراسات العربية: : محنية

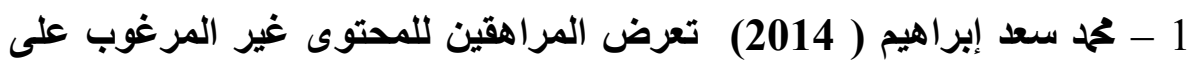

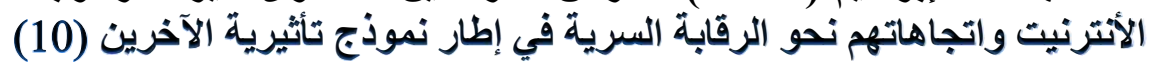

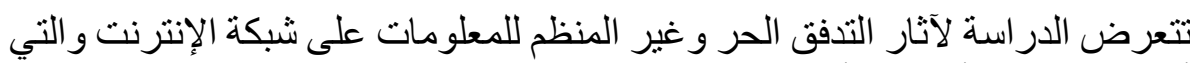

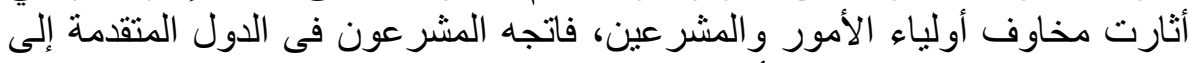

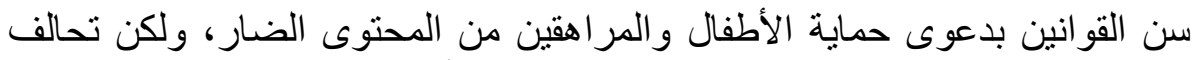

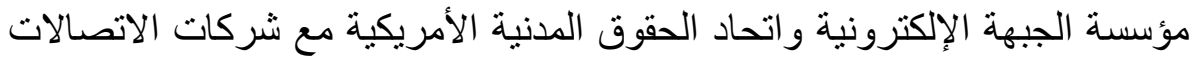

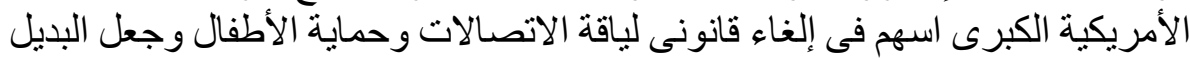

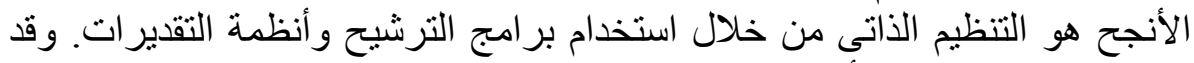

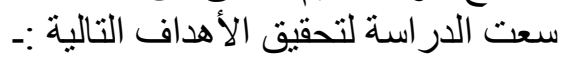

1- التعرف على معدلات تعرض المر اهقين للمحتوى غير المر غوب للإنترنت . 


$$
\text { 2- التعرض لأنماط الرقابة الأسرية على استخدام المر اهقين للإنترنت . }
$$

3- تحديد أنماط السلوك الاتصالى للمر اهقين فى التعامل مع الرقابة الأسرية.

وتضمنت عينة الدر اسة (396 مفردة) من طلاب المدارس الثانوية بمدينتى المنيا

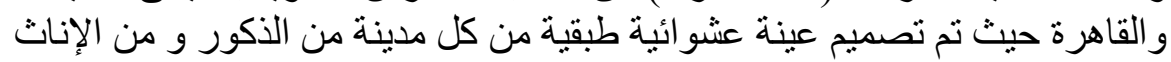

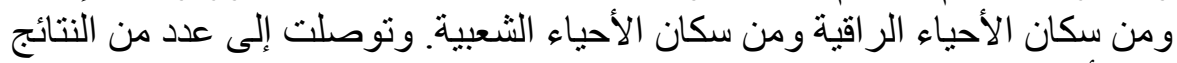
نذكر أهمها :-

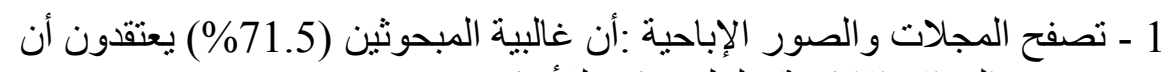

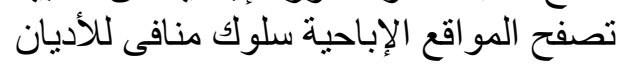

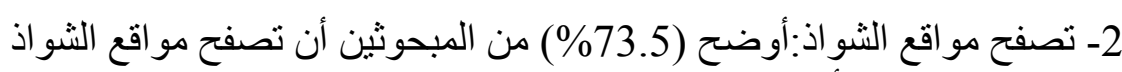 سلوك منافى للأديان

3ـ أقامه علاقات مع الجنس الأخر :أوضح (40.7\%) أن إقامة علاقات غير شردية عية

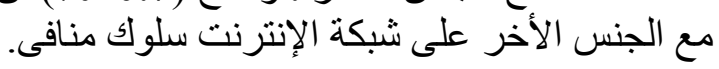

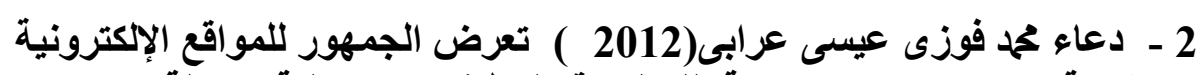

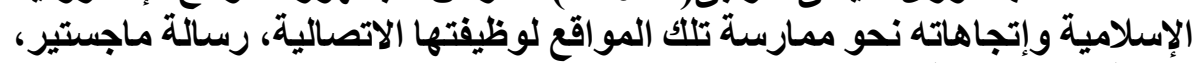
جامعة المنيا : كلية الآداب.(11)

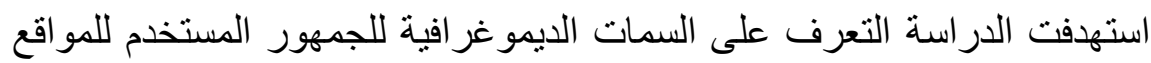

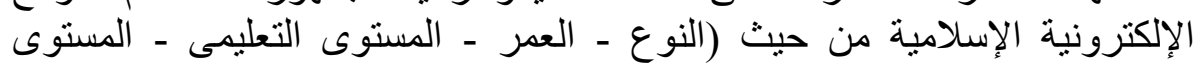

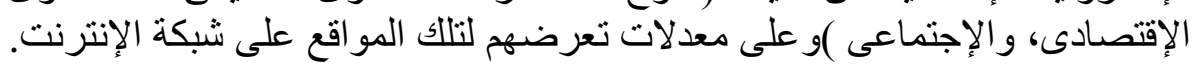

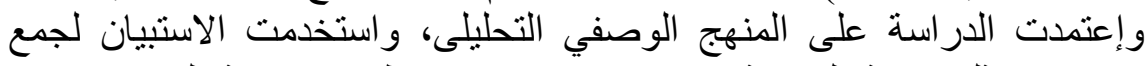

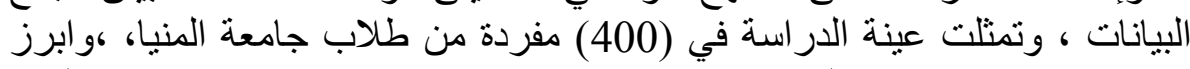
نتائج

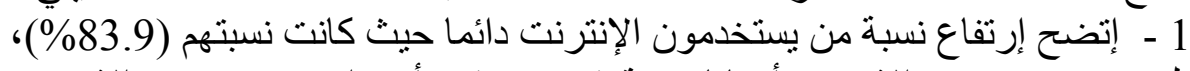

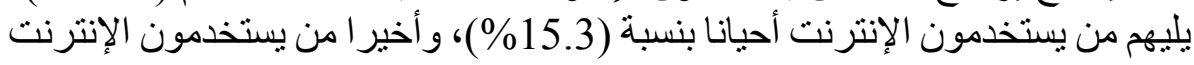
نادرا وبنسبة (0.8\%).

2 - وجود فروق دالة إحصائيا بين المستويات التعليمية الثناثة فيما يتعلق بمعدل

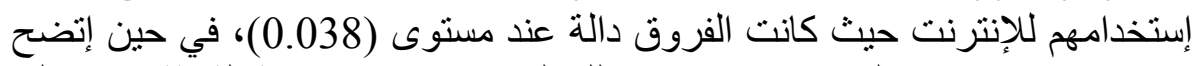

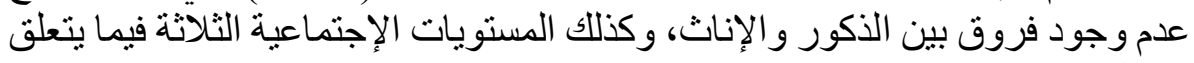

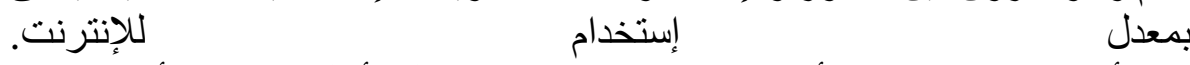

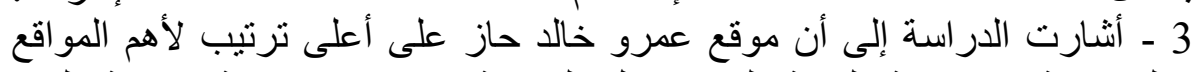

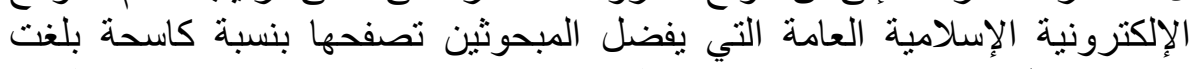

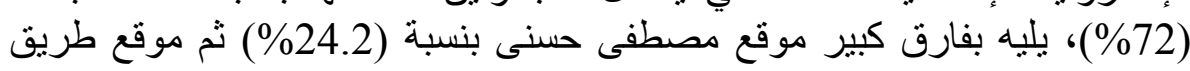

الإسلام بنسبة (\%)، (22.1\%). 
3 - دراسة وسام فاضل راضي وطالب عبدالمجيا: ( 2010 ) التعرض للمسلسلات

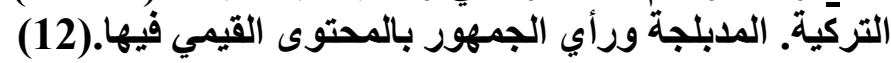

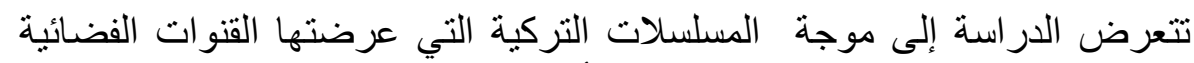

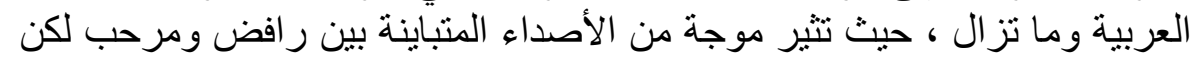

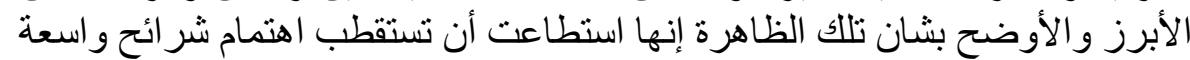

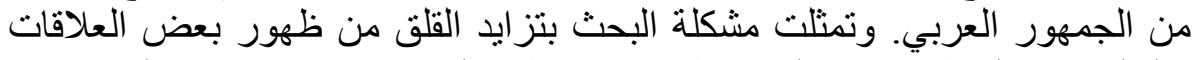

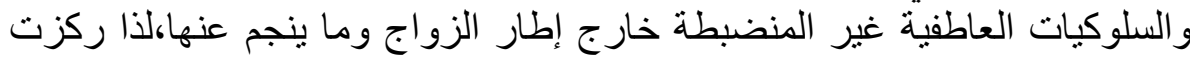

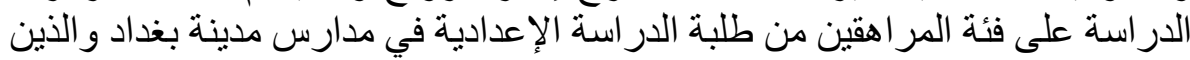

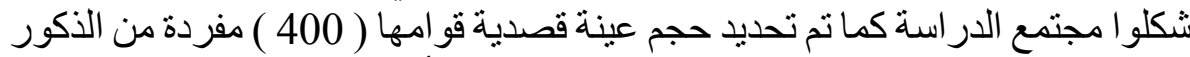

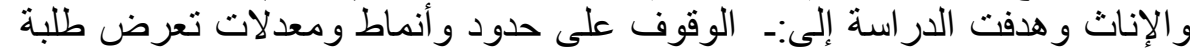

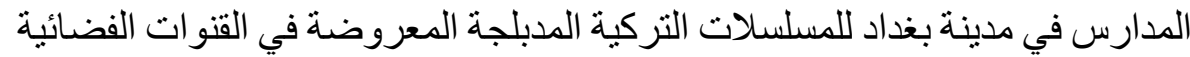

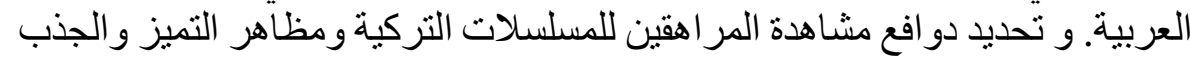

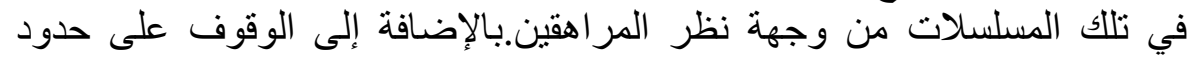

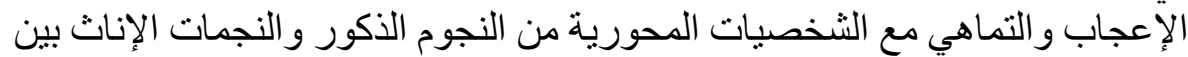

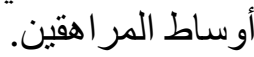
ونذكر ابرز نتائج الدراسة :- المبن

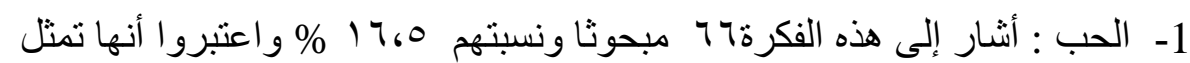

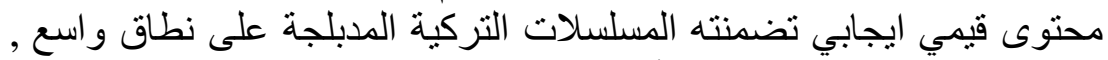

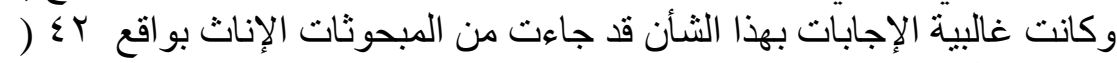

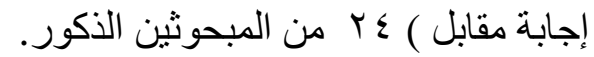

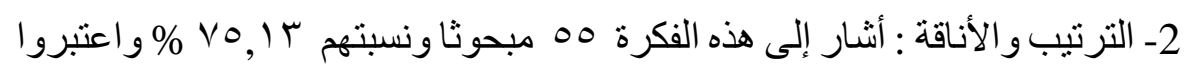

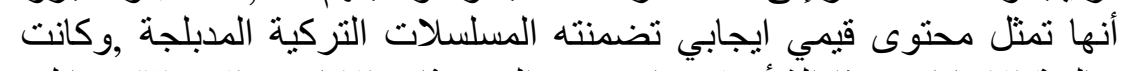

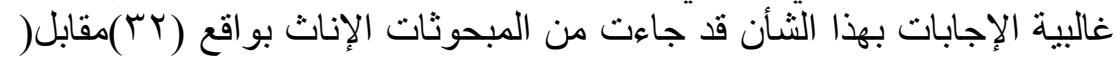

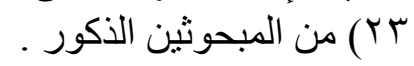

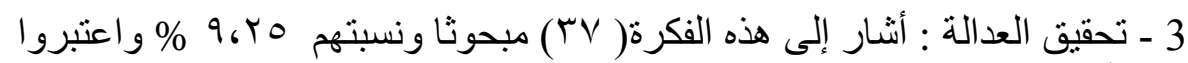

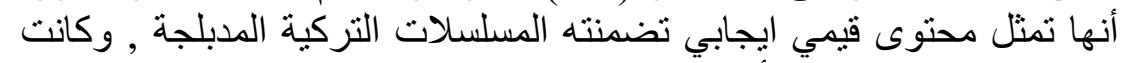

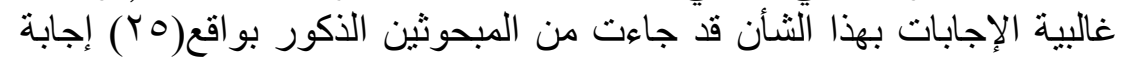

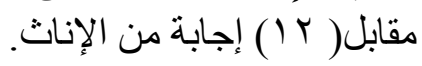

4 - عبد العزيز الطوخي : ( 2008 ) دوافع تعرض تلاميذ الإعدادي للمواد التعليمية

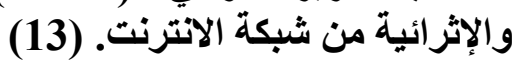

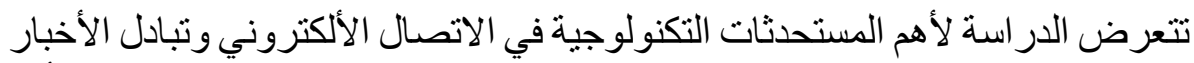
و المعلومات بين الثبكات، وللانترنت العديد من المزايا والحقائقائق التي تجعله من أهم 


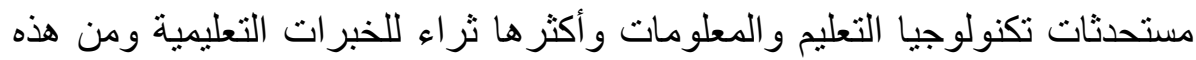

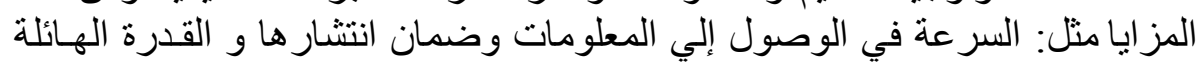

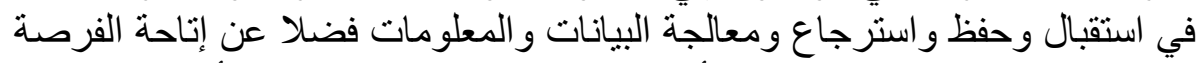

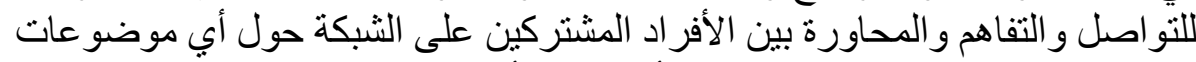
تهمهم ،وقد سعت الدر اسة لتحقيق عده أهدف من أهمها :

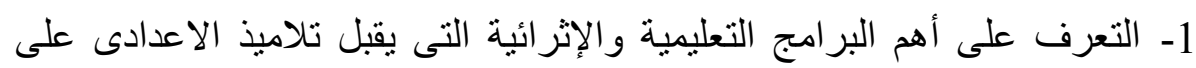
التعرض لها من شبكة الانترنت التع 2- التعرف على سلبيات وإيجابيات استخدام شبكة الانترنت في التعليم . تعتمد هذه الدر اسة على منهج المسح لعينة متمثلة بجمهور "تلاميذ المرحلة الإعدادية"

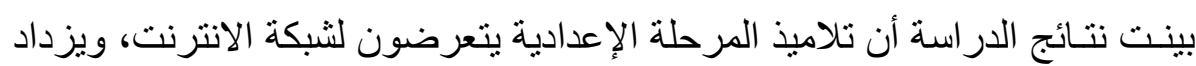

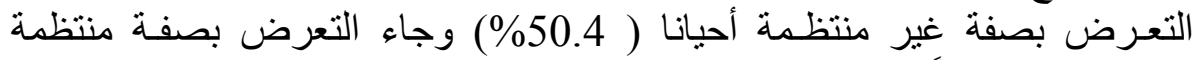
(\%32.1\%)

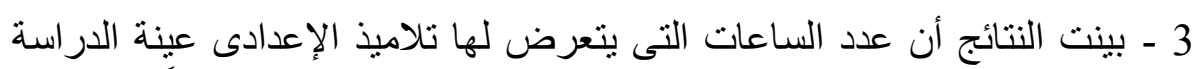

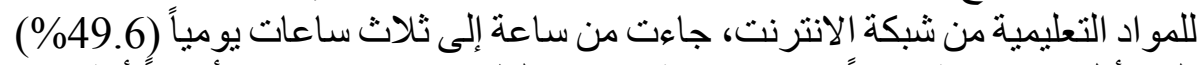

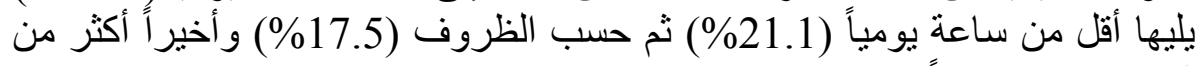

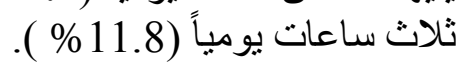

5- دراسة فتحية مرابط (2001 ): استخدامات طلاب جامعة الجزائر للقتوات الفرنسية وما تحققه من إثباعات (14) مرابطة (201)

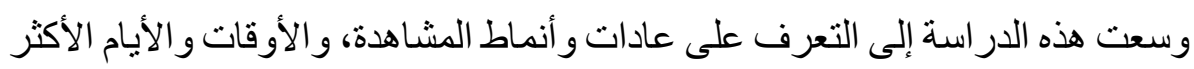

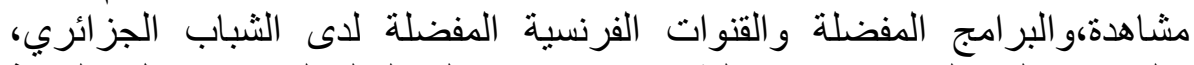

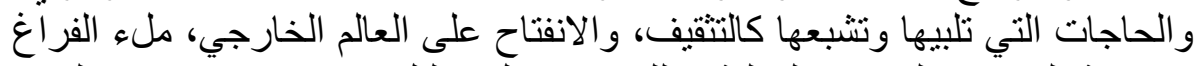

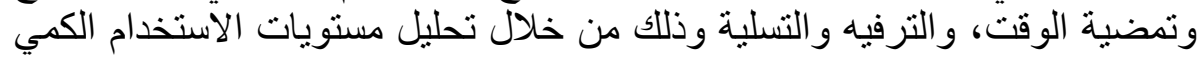

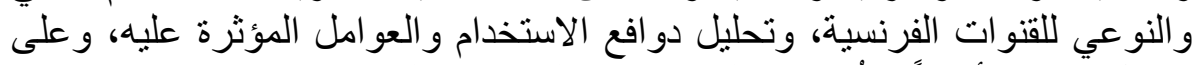

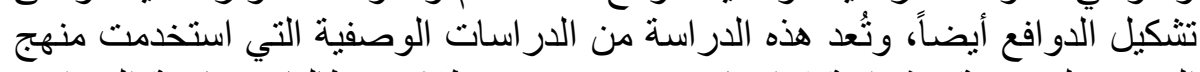

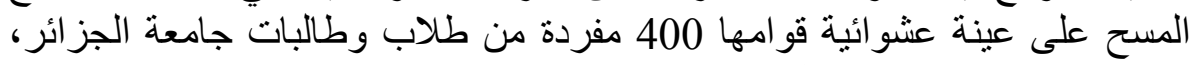

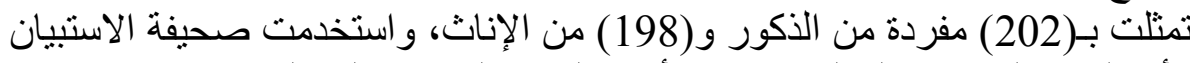

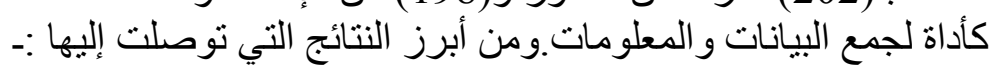

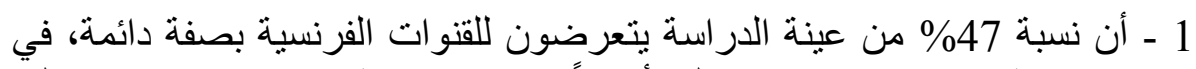

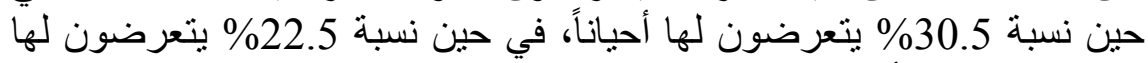

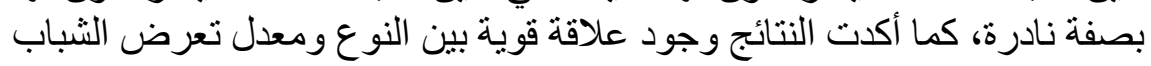
الجامعي للقنو ات الفرنسية وذللك لصالح الصدات الإناث. 


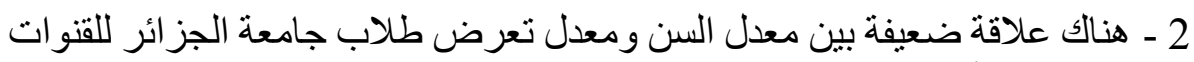

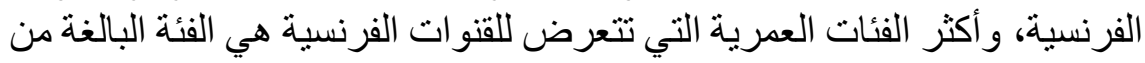
العمر ما بين 21- 24 سنة.

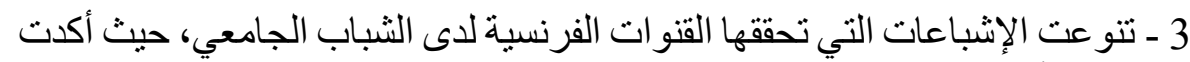

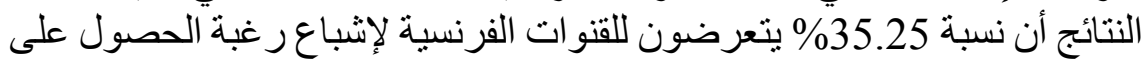

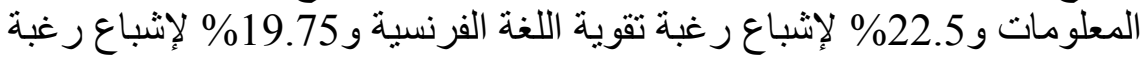

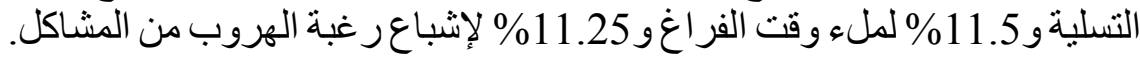

6- نجوى عبد السلام: "أنماط ودوافع استخدام الشباب المصري لشبكة الإنترنت، دراسة استطلاعية. (15) استهدفت الدر اسة التعرف على الاستخدامات المختلفة للثباب المصر التهي لثبكة الإنترنت

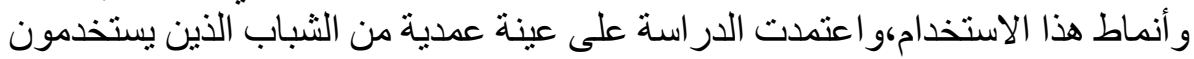

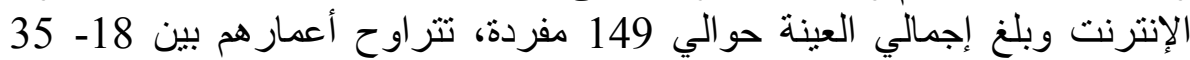

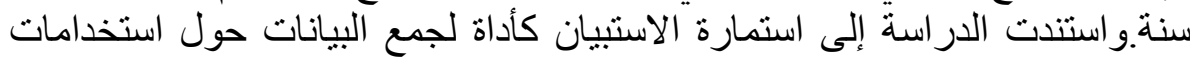

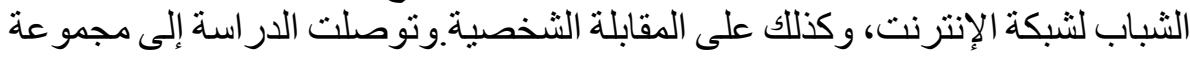

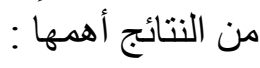

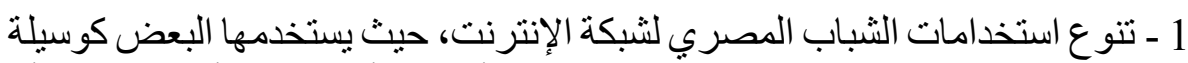

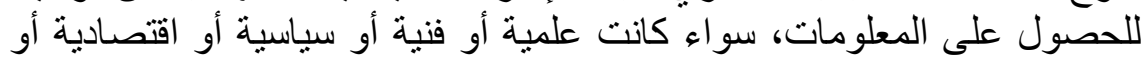
رياضية.

2- الثباب يميلون إلى استخدام الإنترنت بكثافة، وبلغ من يستخدمونها بشكل يومي في في الإني

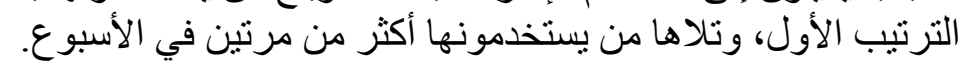

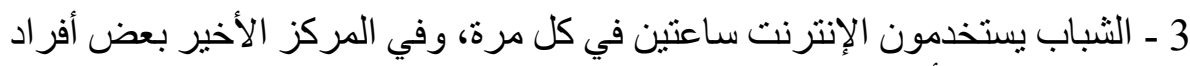

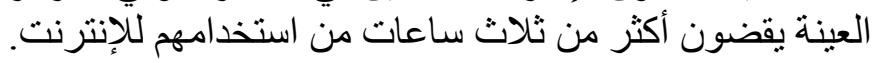

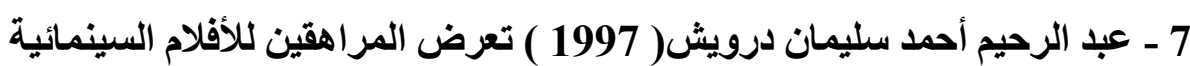
والإشباعات التي تحققها.(16)

اتجهت هذه الدر اسة إلى التعرف على دو افع تعرض المر اهقين للأفلام السينمائية

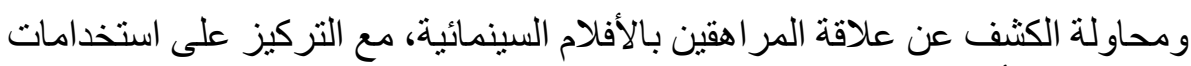

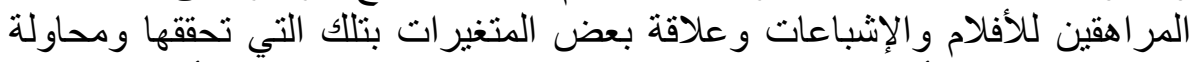

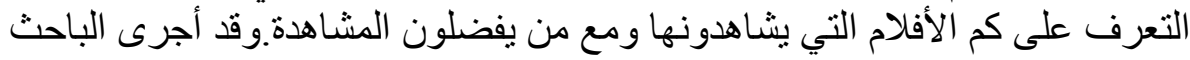

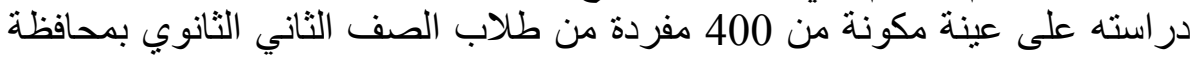

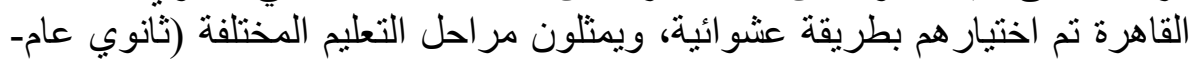


عام لغاتـ تجاري- صناعي).واعتمدت الدراسة على أداة الاستبيان كأداة لجمع التها

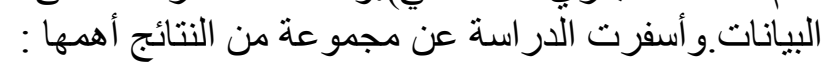

1 - أكثر فئة نتردد على دور العرض السينمائي هم من عُمر 13: 18 سنة ويؤثر

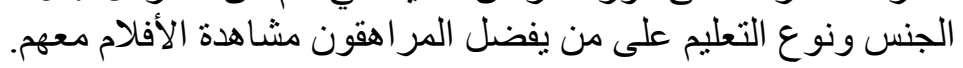

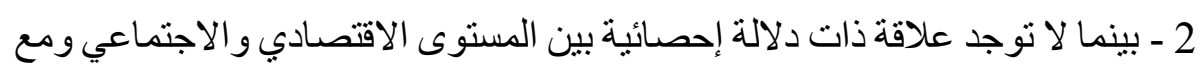
من يفضل المر اهق المشاهدة.

3 - أن عينة الدراسة من المراهقين يتعرضون للأفلام السينمائية بنسبة 100\%

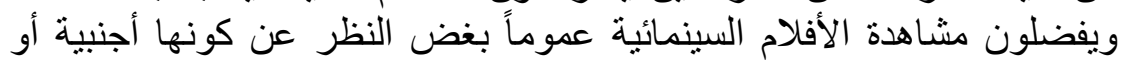
عربية في دور العرض من أكثر من الفيديو أو التلبفزيون.

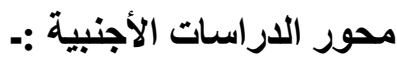
1- - ـدراسة روش أنتوني (12015) بعد دراكولا : أفلام الرعب في حقبة

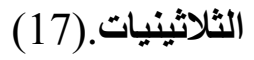

تسلط هذه الدر اسة الضوء على حقبة بالغة الأهمية أسست إلى بدايات التحول النوعي

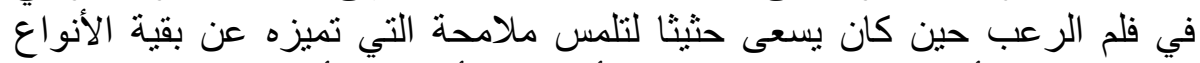

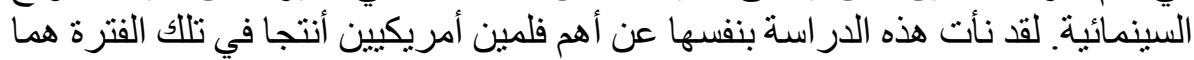

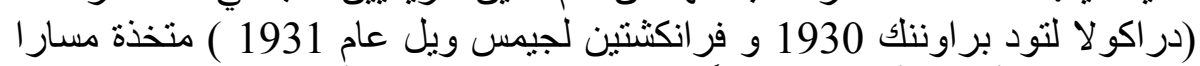

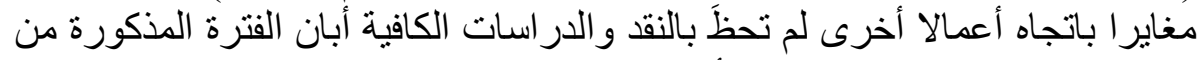

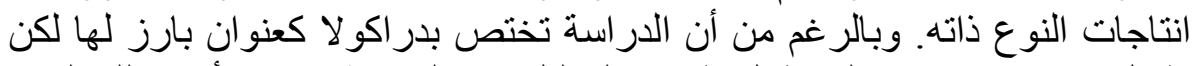

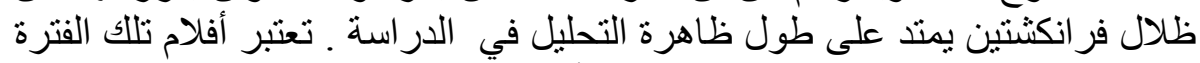

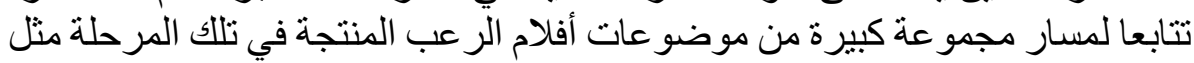

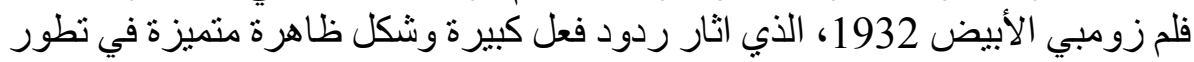

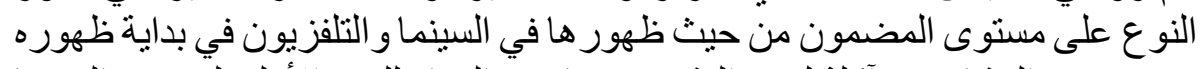

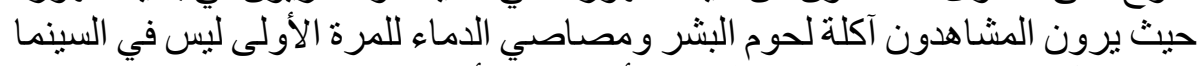

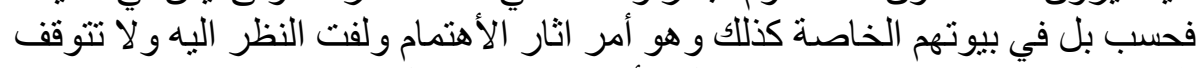

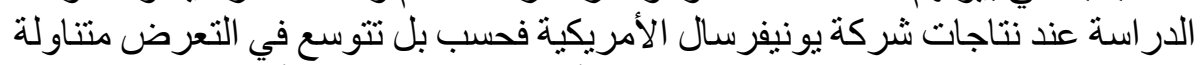

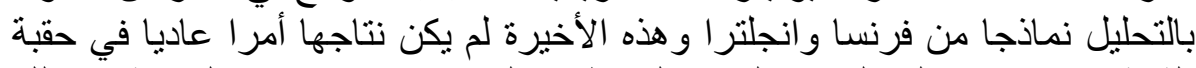

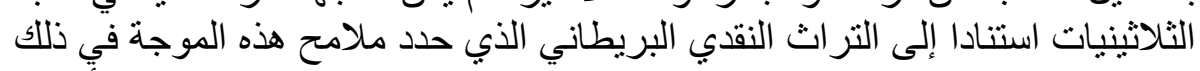

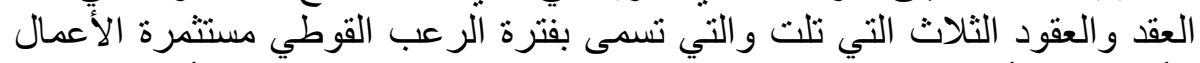

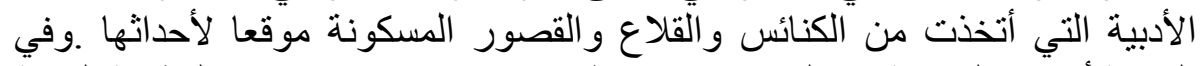

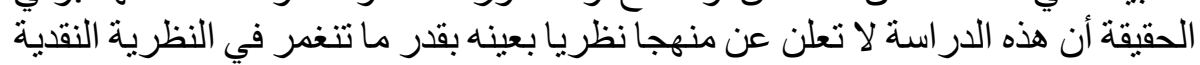

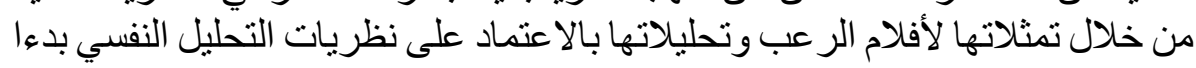
من فلم كارل در ايير مصاص الاصلاء الدماء المنتج عام 1929 ـ 
2ـ دراسة إيان اولني ( 2013 ) الرعب الأوروبي: سينما الرعب الكلاسيكية الأوروبية

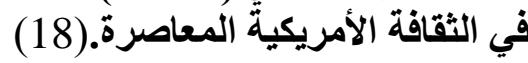

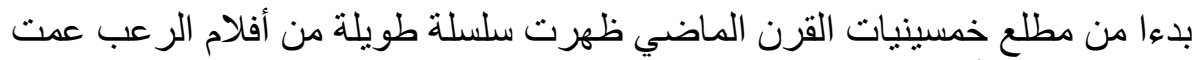

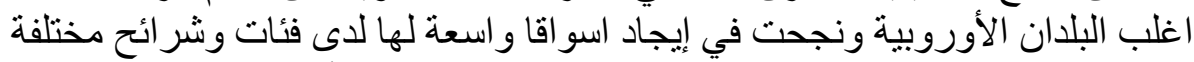

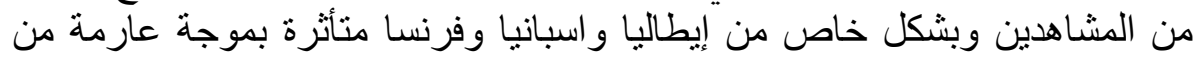

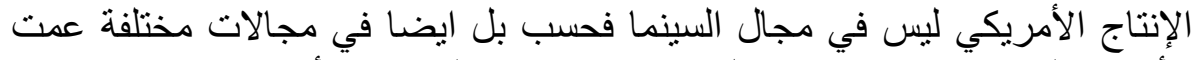
الأدب والمسرح،إذ راقبت بشكل صارم الإنتاج السنوي الألمريكي وحذت الإلت حذوه

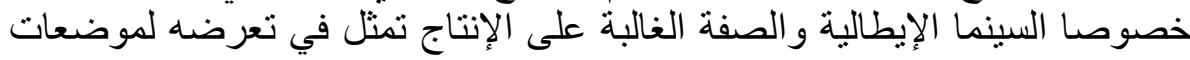

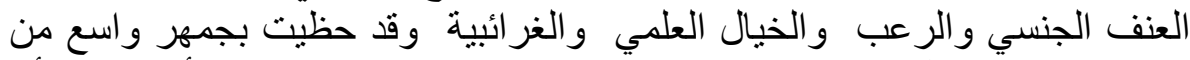

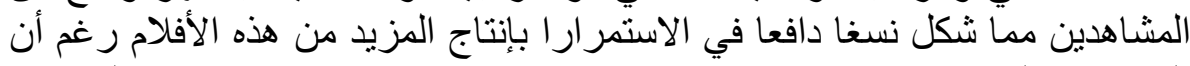

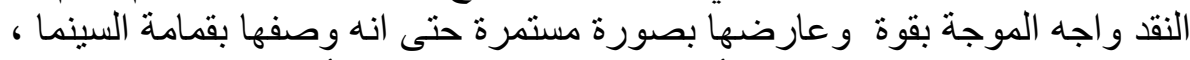

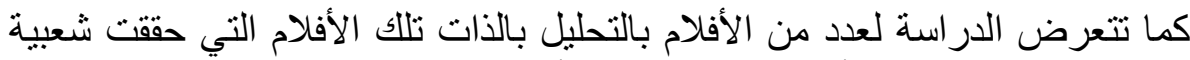

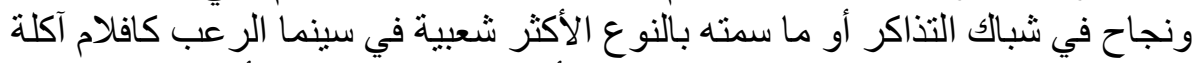

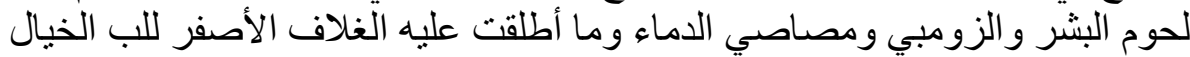

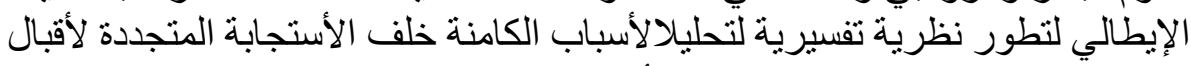
الجماهير على مشاهدة هذا النوعة نفيرية من الأفلام.

3- سوبولكسي مولتر ،ولوكيس (2003) الجنس والعنف في افلام الذباحين - إعادة

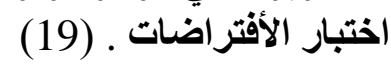

لقد أعتمدت الدر اسة على اداة تحليل المحتوى لعينة من اشهر أفلام الرعب الربت التي أنتجت

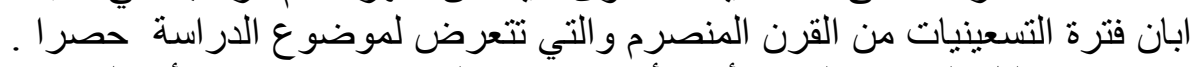

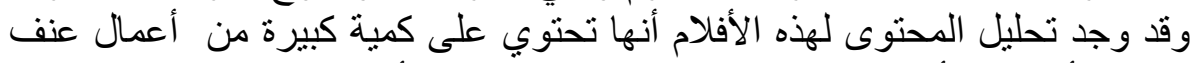

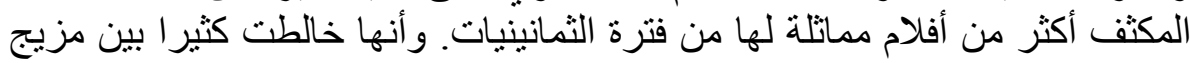
صادم قو امه الخلط بين العنف والجن والجنس.

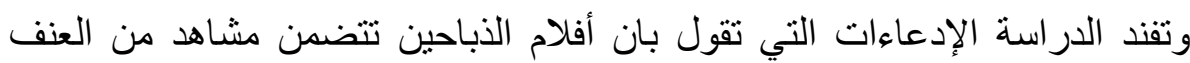

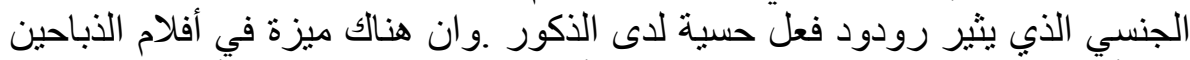

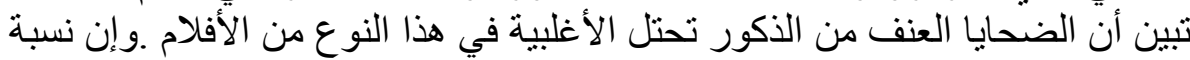

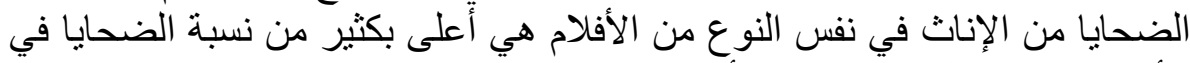

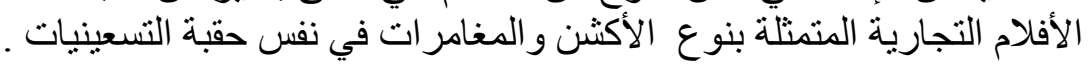
4 ـ دراسة جاك مورجن: ( 2002 ) بيولوجيا الرعب : الأدب القوطي والقلم .(20)

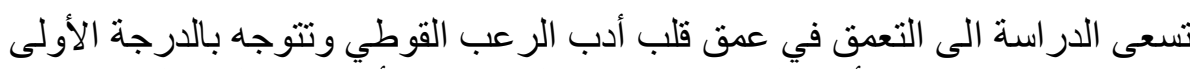

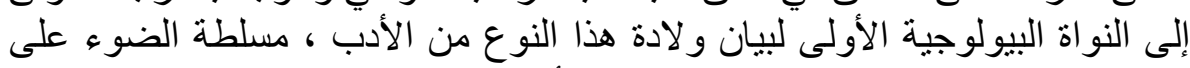
الخصائص والسمات التي تميزه عن باقي الأدب لإن الروائي كاثثفة عن العناصر الأبر الفنية 
و النفسية التي ناقتت بإستفاضة مفهوم التحولات التـأريخية التي طر أت على الأدب

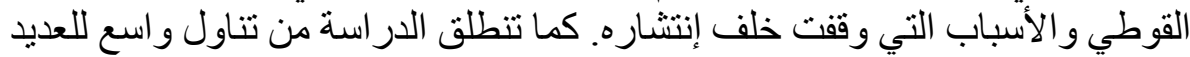

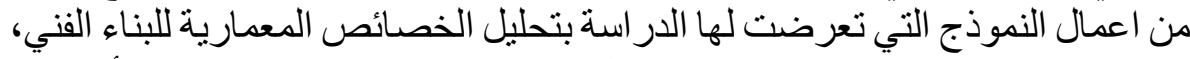

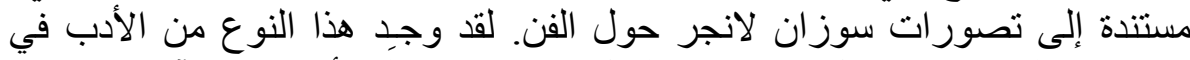

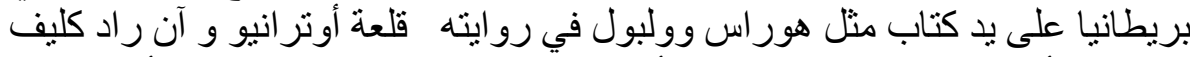

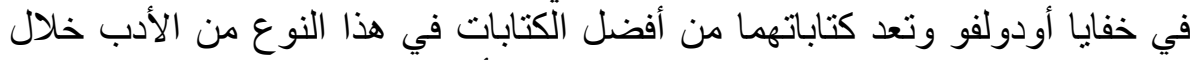

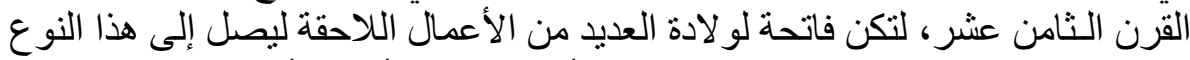

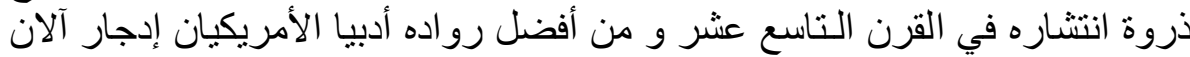

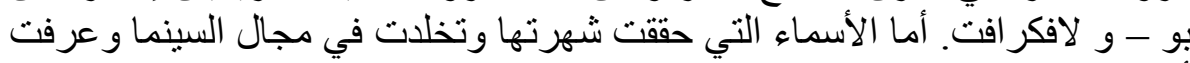

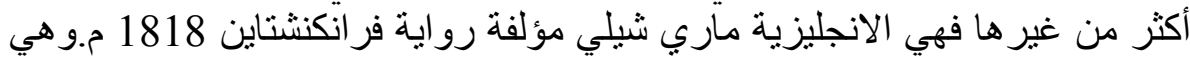

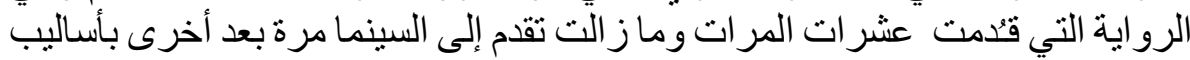

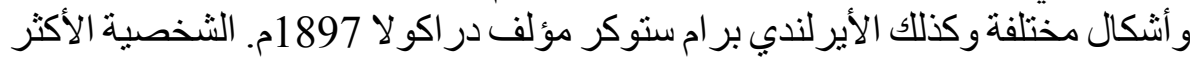

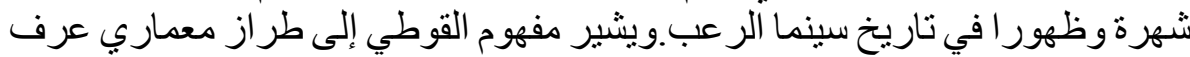

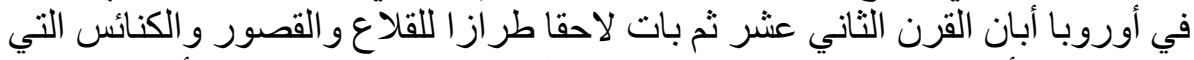

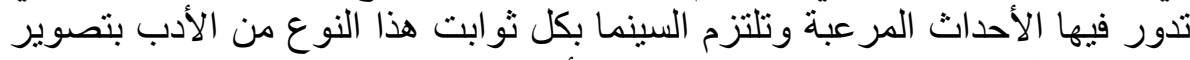

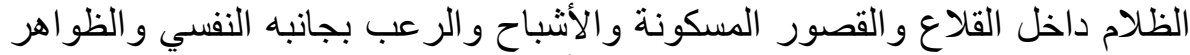
الخارقة والقوى غير الطبيعية والضباب والأسرار و الثخصيات التخات الغامضة التي يدور

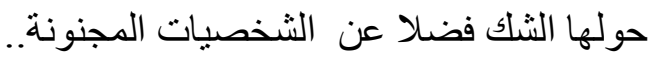

5- دراسة جورج،أي،سلوسير و أريك ،س، ربكن : (21) (1987) الغرباء :إنثروبولوجيا الخيال العلمي (21)

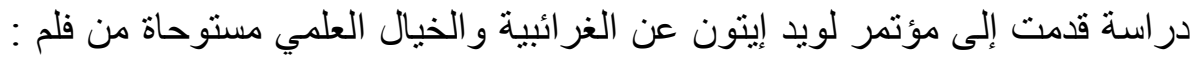

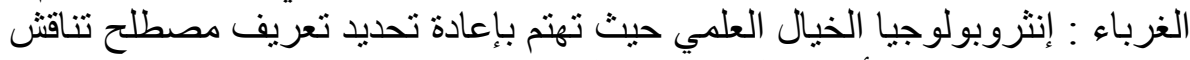

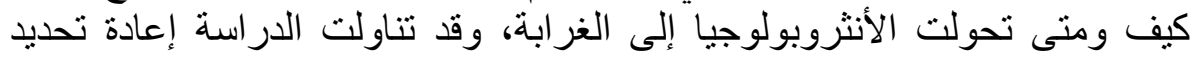

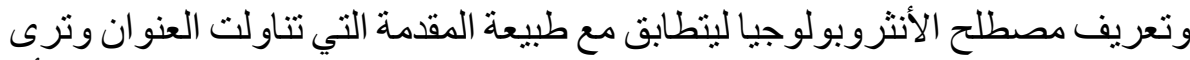

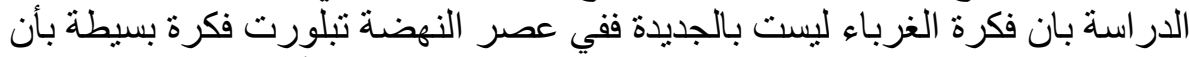

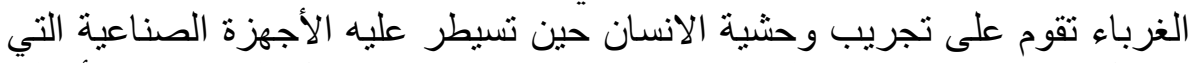

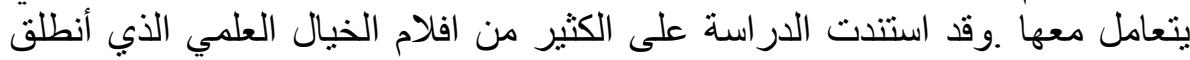

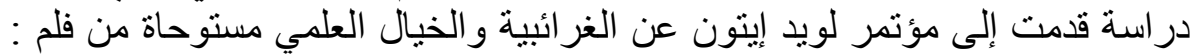

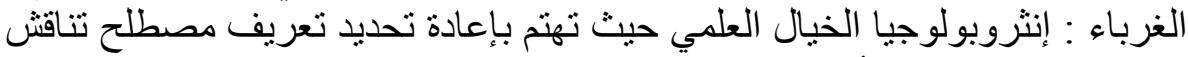

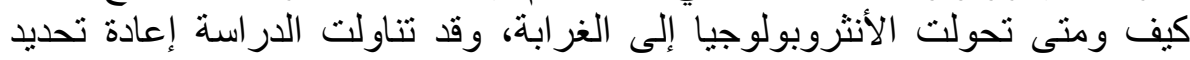

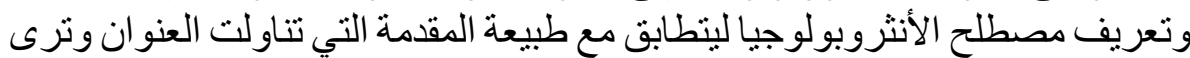

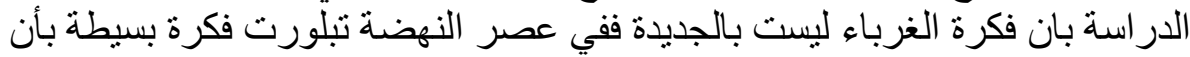

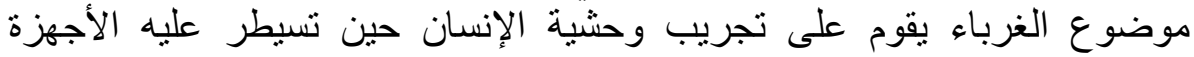

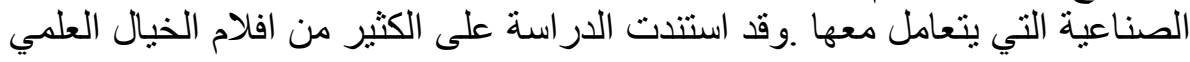




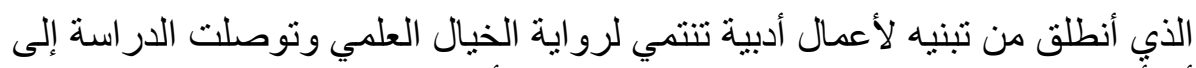

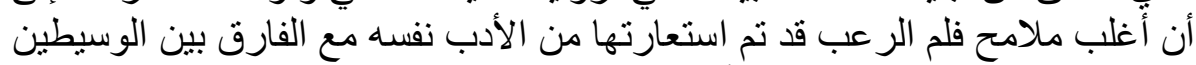

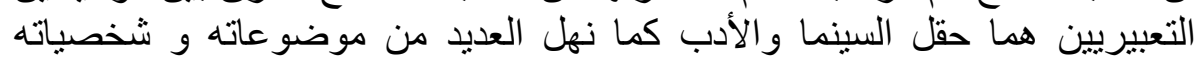

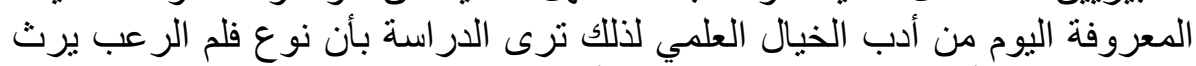

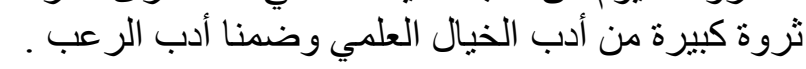

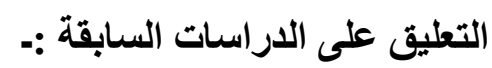

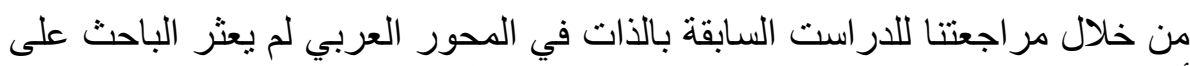

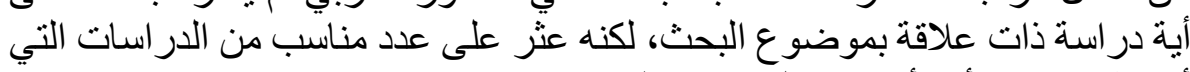

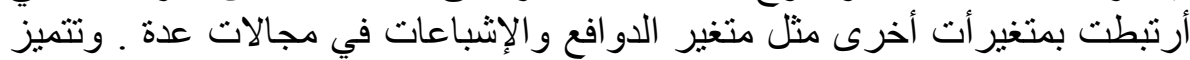

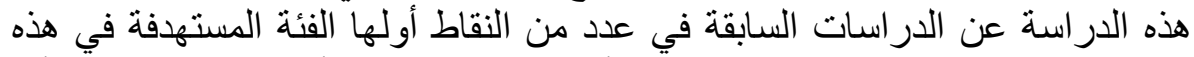

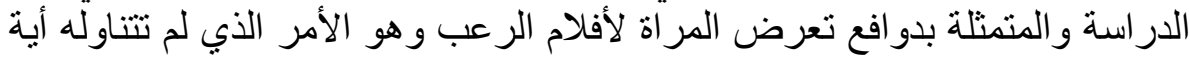

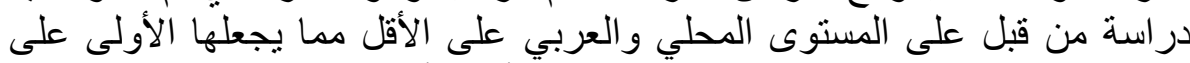

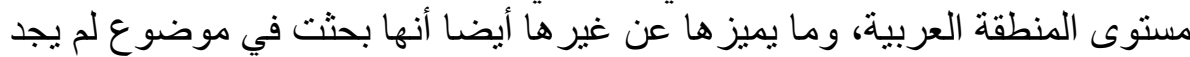

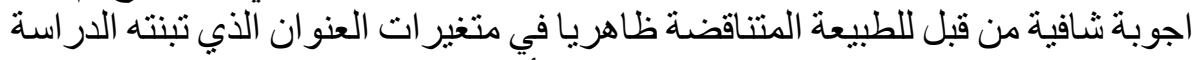

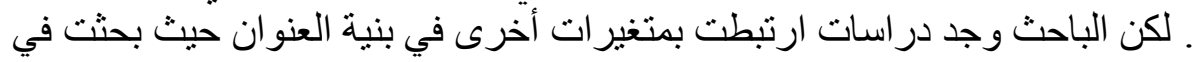

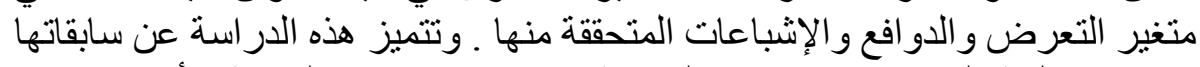

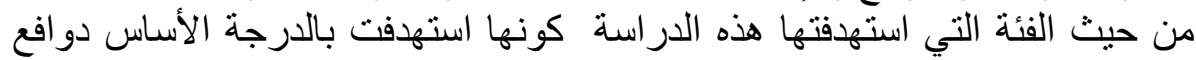

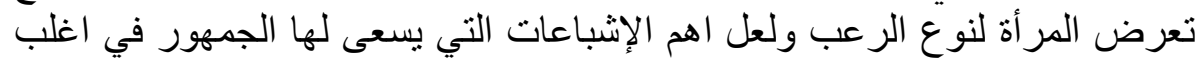

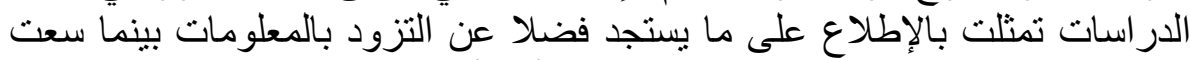

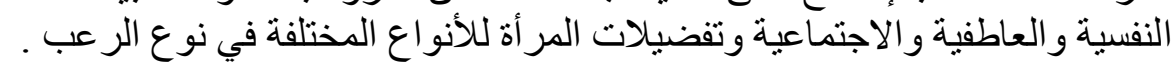
أوجه الأستفادة من الاراسات السابقة:-

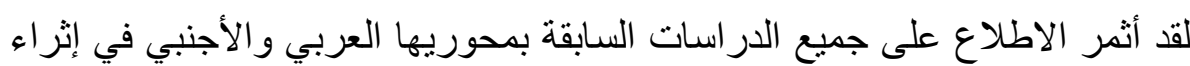

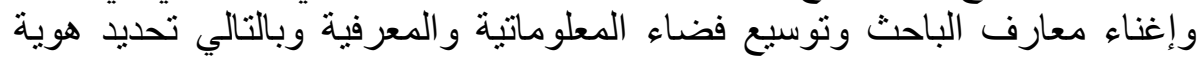

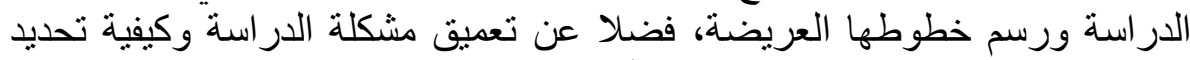

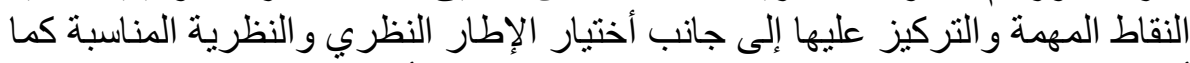

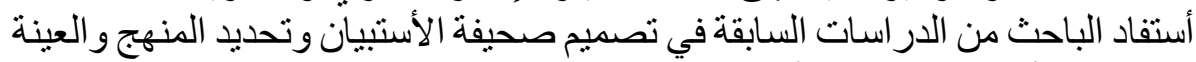

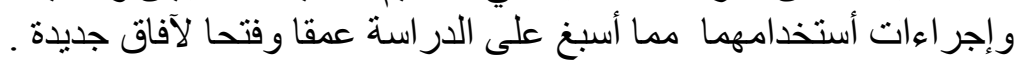

الفصل الثانى الإطار النظري للارباسة

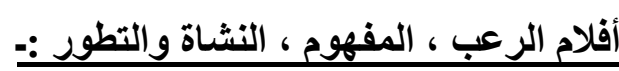

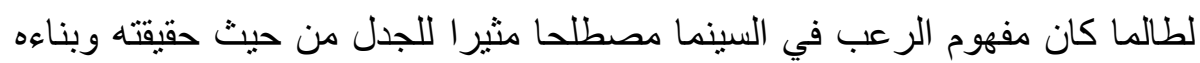

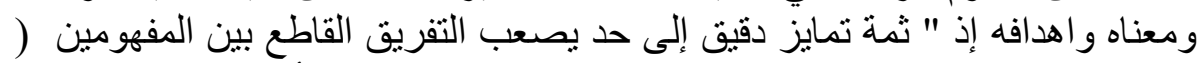
(Terror 
( Horror )

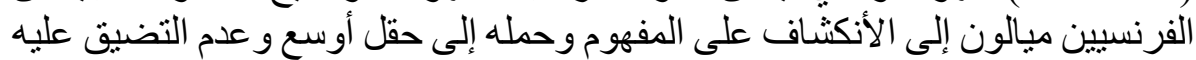

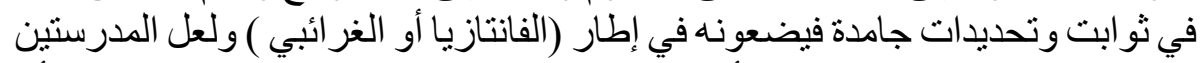

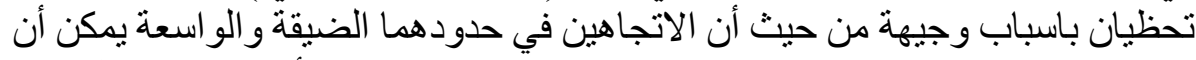

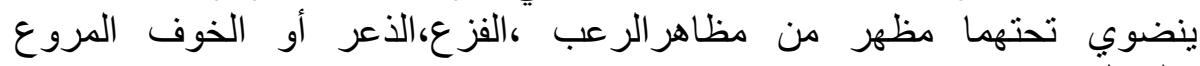
و الخيال.(22).

ومع ذللك فإن قاموس المورد يعرف ( Horror ) "بالر عب ، الإشمئز از الثديد".(23)

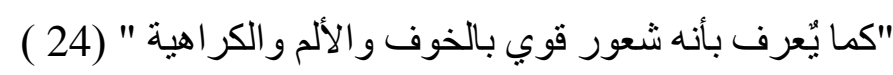

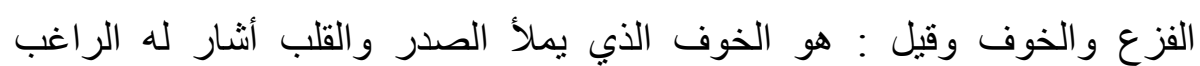

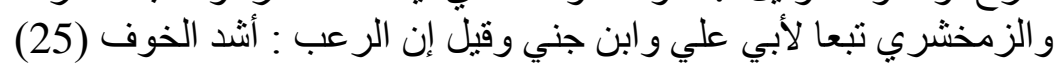

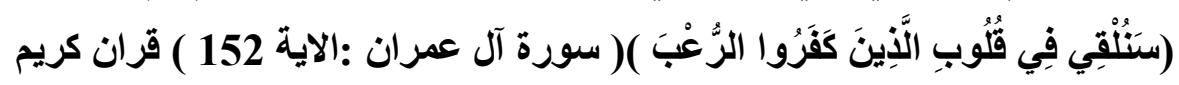

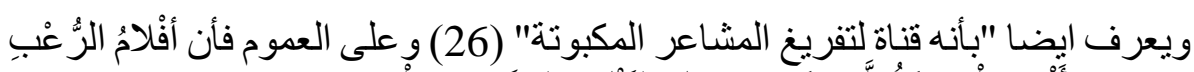

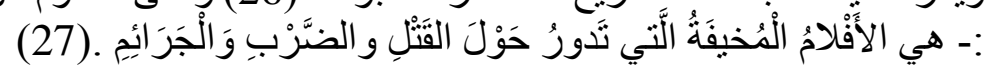

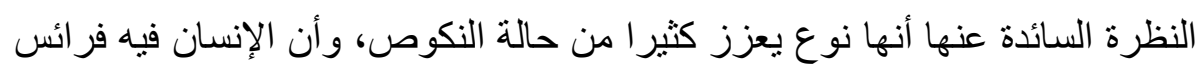

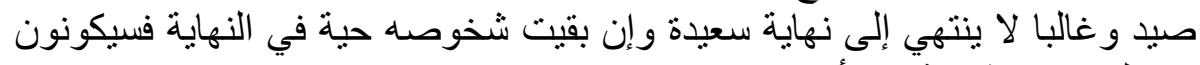

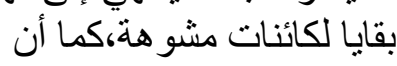
الر عب قادر على خلق حالة من القلق والأضطر اب النفسي وكثير ا ما يرتبط بالمكان

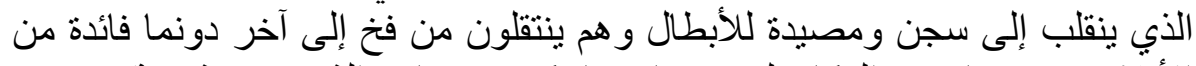

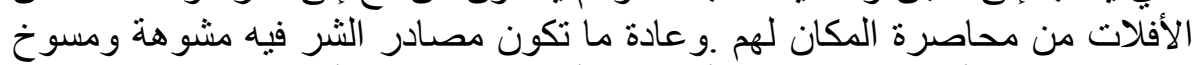

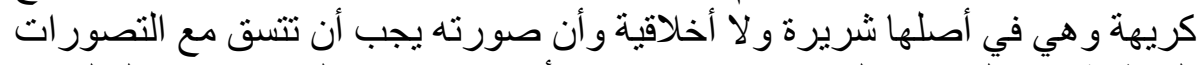

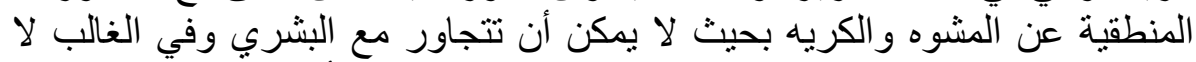

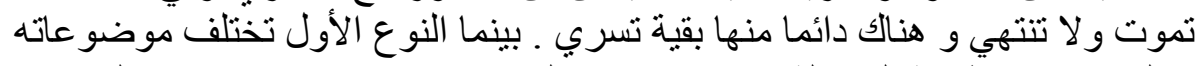

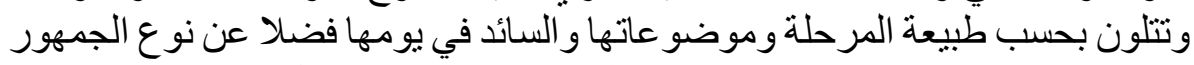

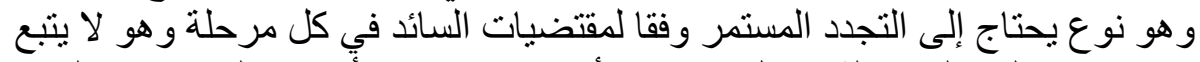

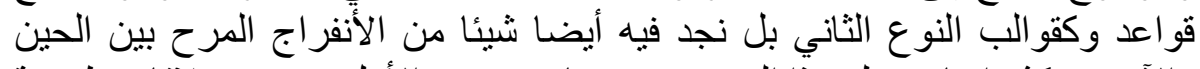

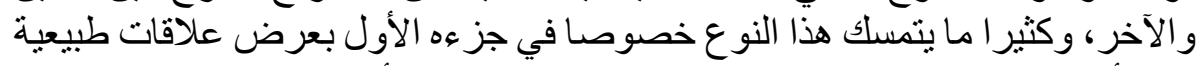

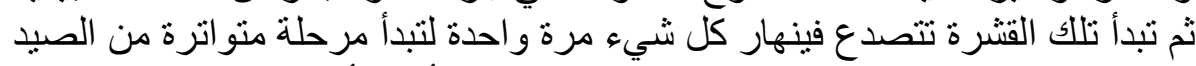

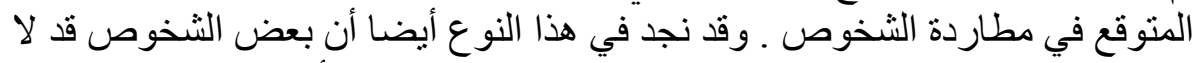

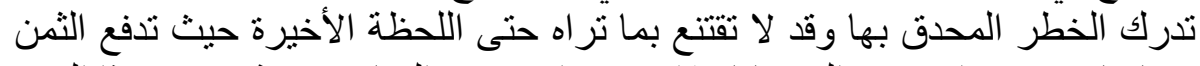

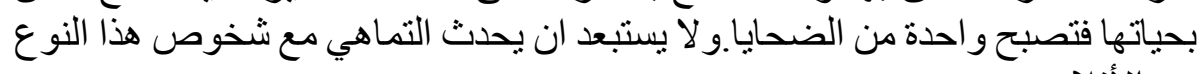

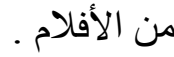


و عادة ما تأتي الثرور بصورة مسوخ أو تقصصات أو شخوص تتلبسها الثرور فضلا عن المتحولين و المستذئبين ... عادئ

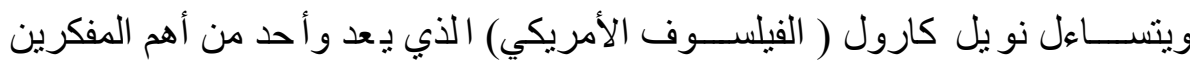

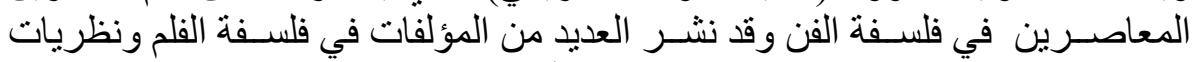

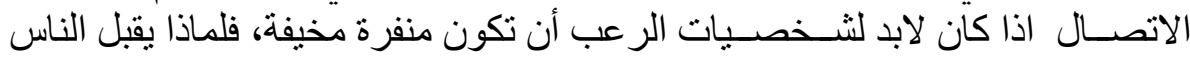

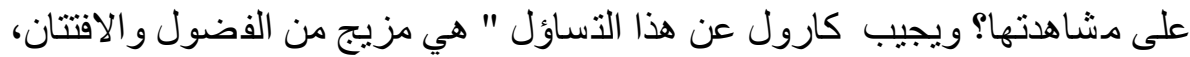

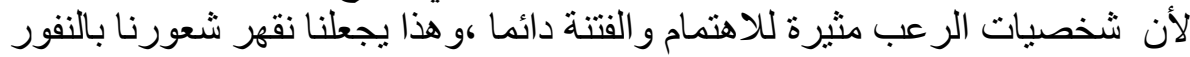

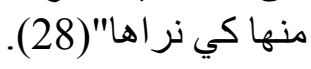

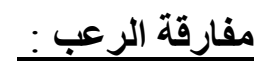

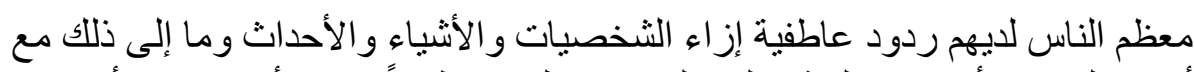

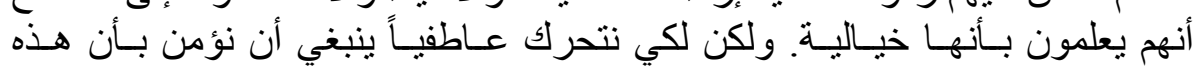

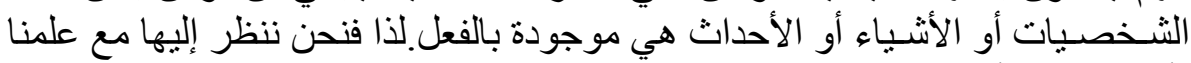
بأنها خيالية و أنها حقيقية في نفس الأوقت.

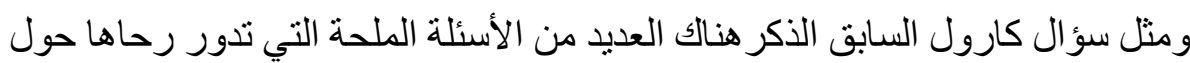

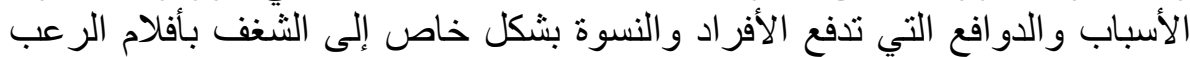

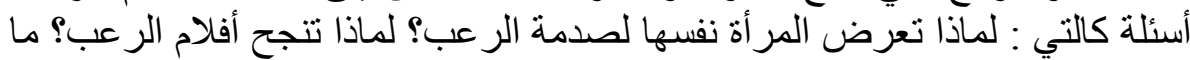

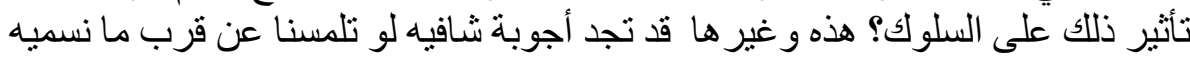

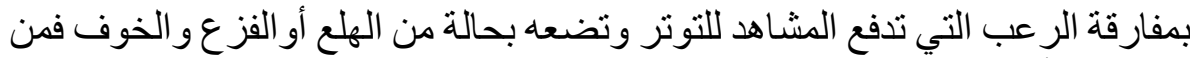

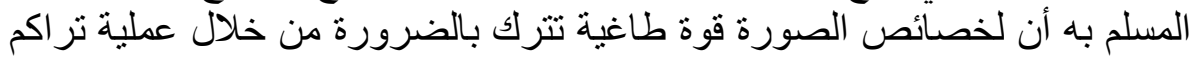

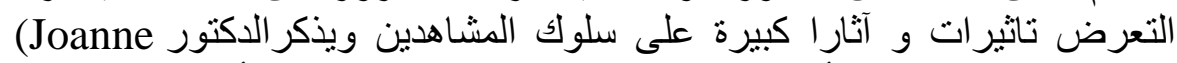
Cantor)

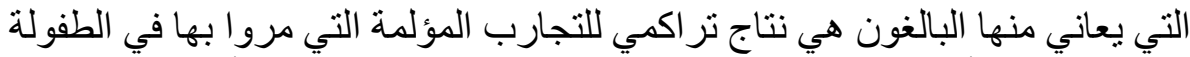

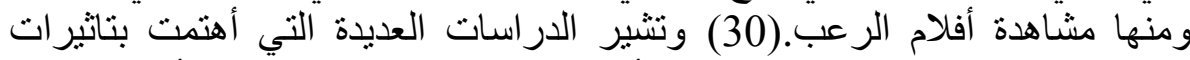

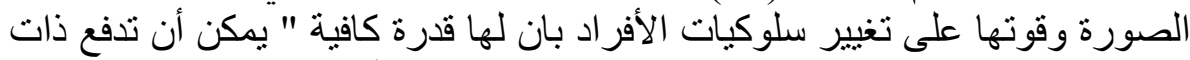

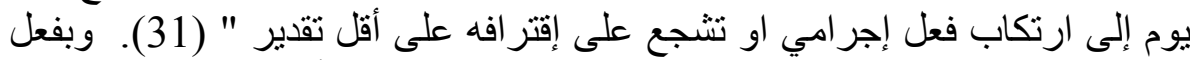

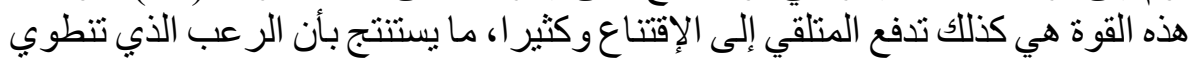

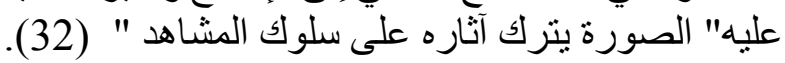

وثمة دراسات مبنية على فرضيات سيكولوجية تتركز بشكل خاص على تلى تأثيرات

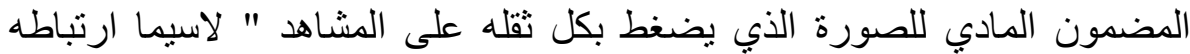

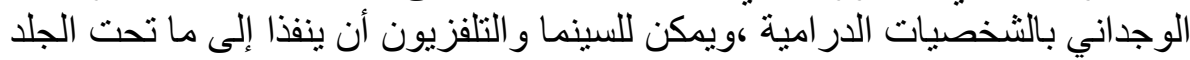

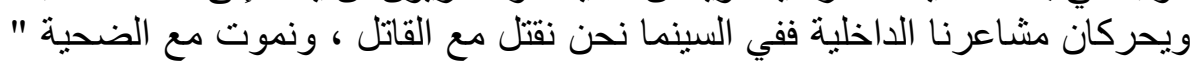

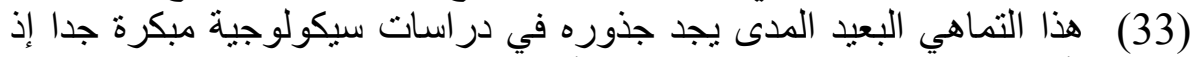

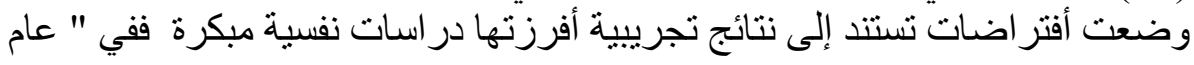


1950 قدمت لجنة رسمية تقرير ا إلى البرلمان البريطاني يستند إلى دراسة أستجوبت

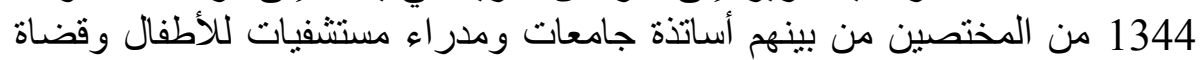

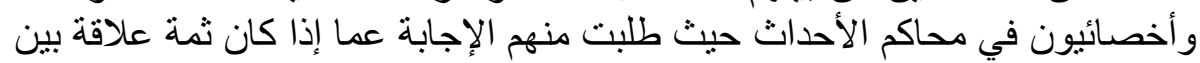
ما بلي:1“، أرتياد السينما والإنحر اف.- ماف.

2 - إرتياد السينما و الإنحطاط الأخلافي.

وقد جاءت 600 إجابة مؤيدة للعلاقة بين إرتياد السينما و الإنحر اف، و و600 إبادية إجابة نفت

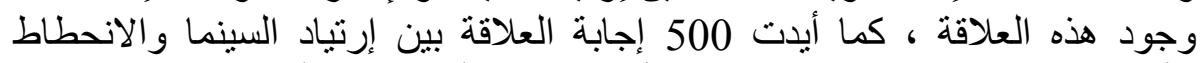

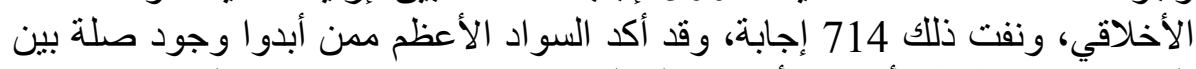

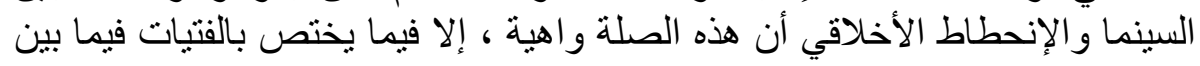

سن12و 16 سنة " (34).

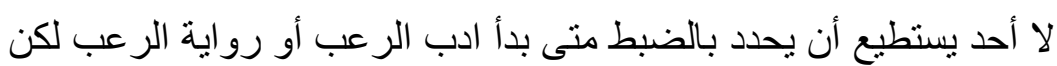

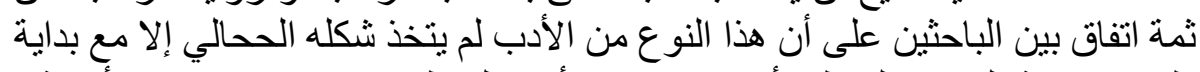

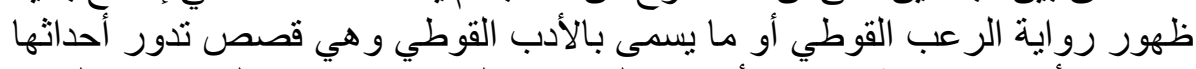

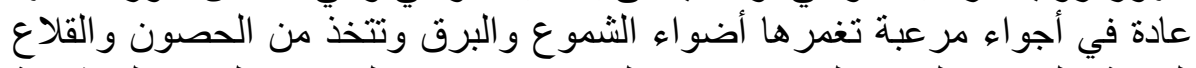

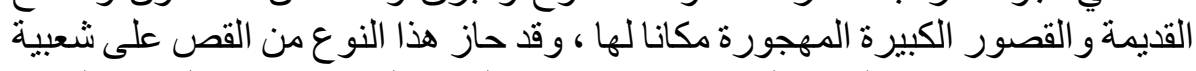

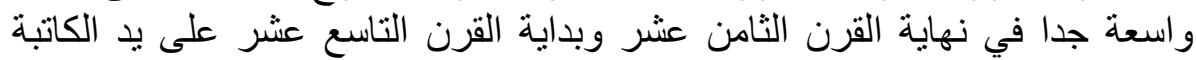

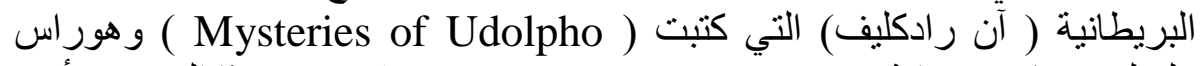

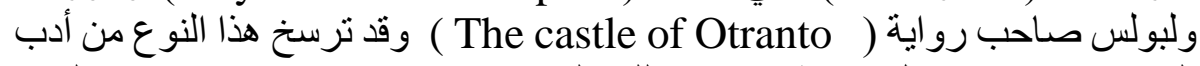

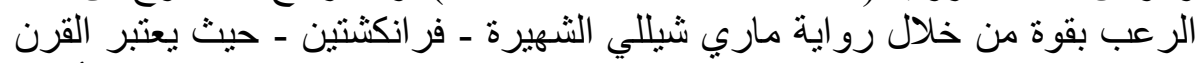

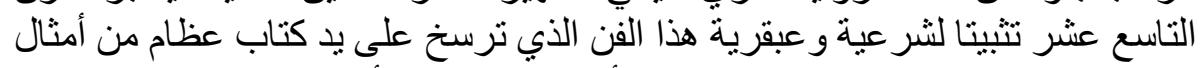

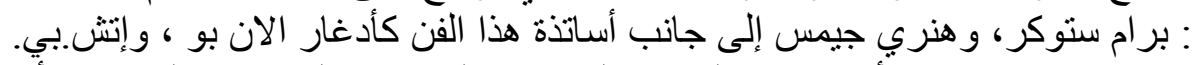

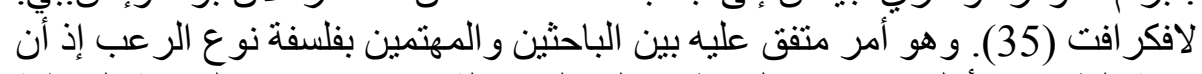

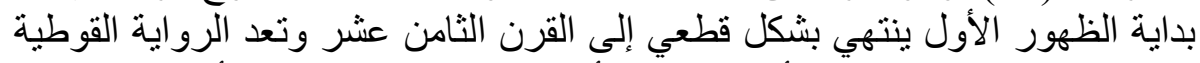

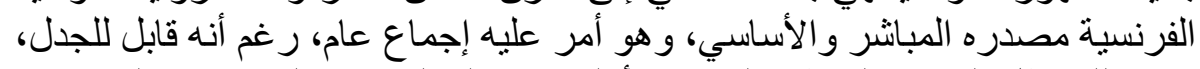

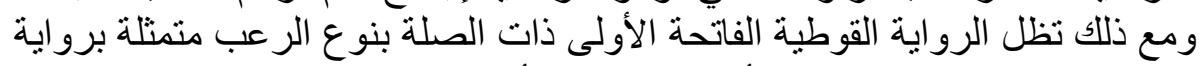

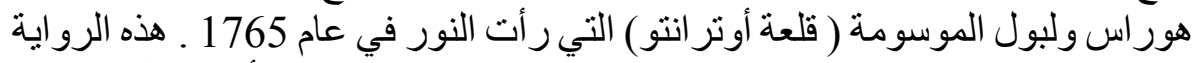

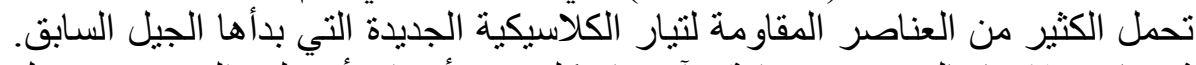

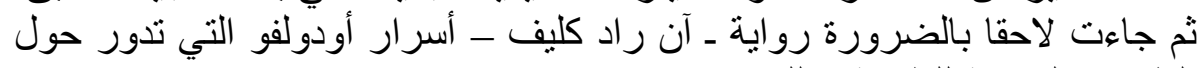

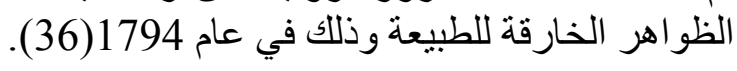

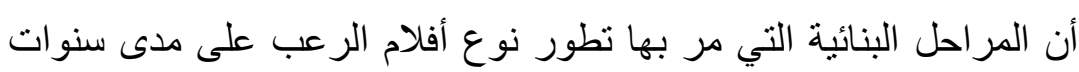

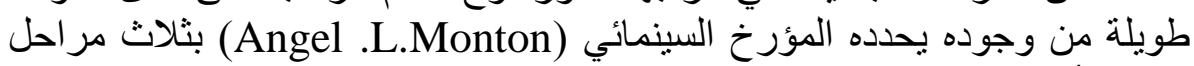
مر احل أساسية رافقت ظهور النوع ونطون النور ملامحه ليصبح كما هو عليه اليوم :- 
1 ـ التشكل الأولي في أوروبا : ويتمثل بكل ما ظهر في سنوات السينما الصامتة .

$$
2 \text { ـ الإنتاج المركز لشركة يونيفرسال }
$$

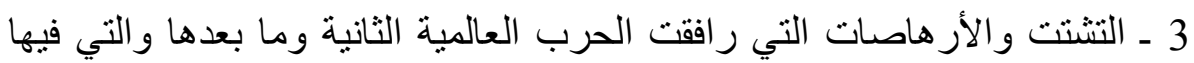

برزت مو اقف وطنية مختلة ومتنو عة وكان لكل موقف ملامحه الخاصة (37).

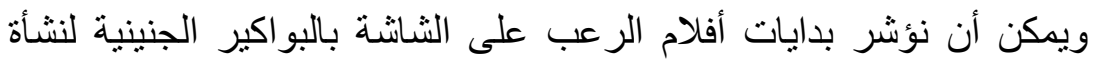

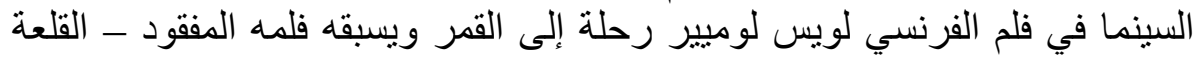

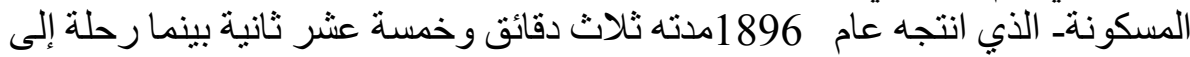

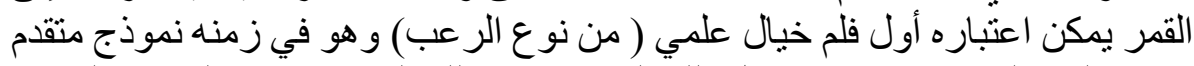

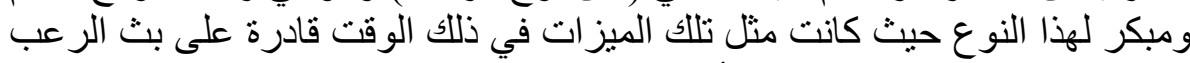

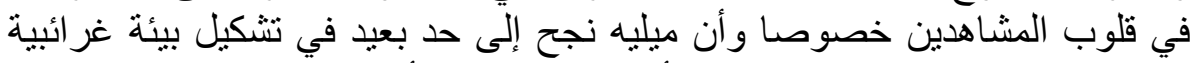

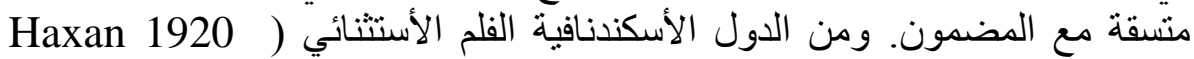

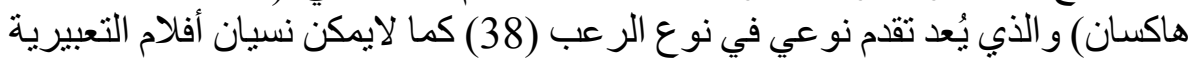

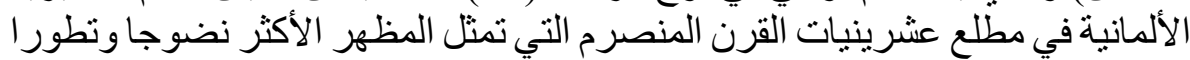

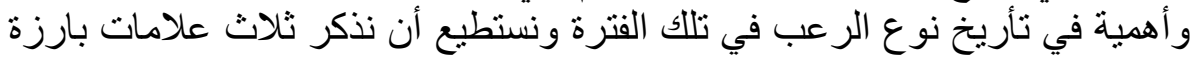

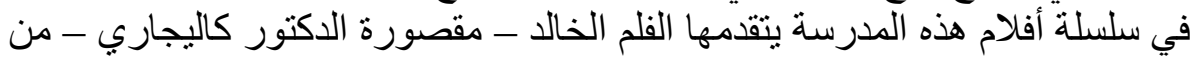

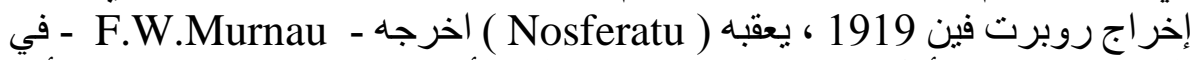

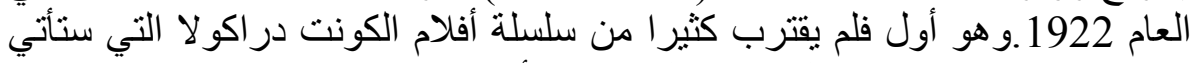

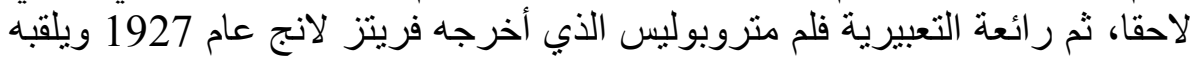

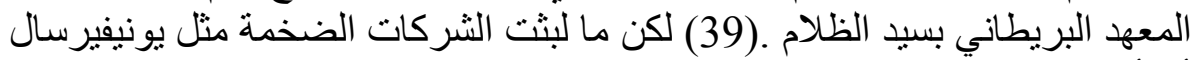

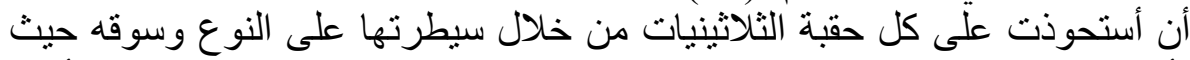

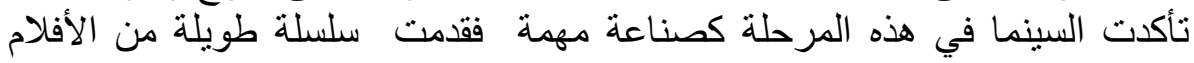

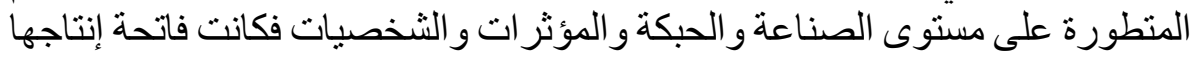

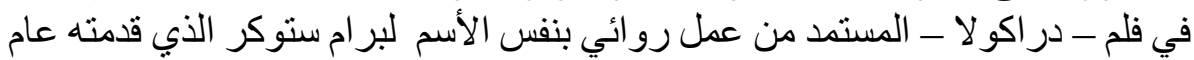

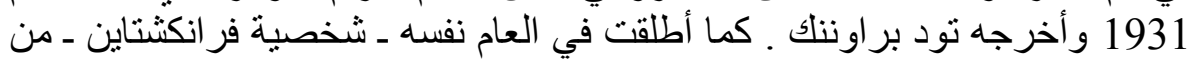
إخر اج جيمس وول و هو من رواية بنفس الأسم لماري شيللي يتبعه فلم المو مياء 1932

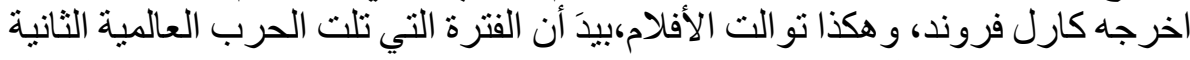

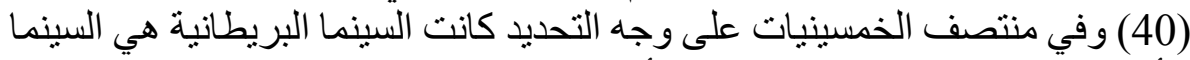

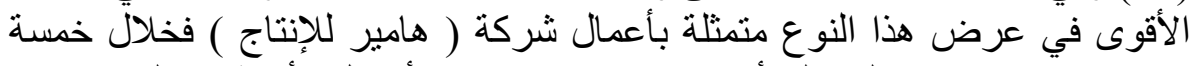

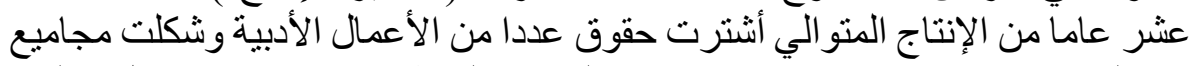

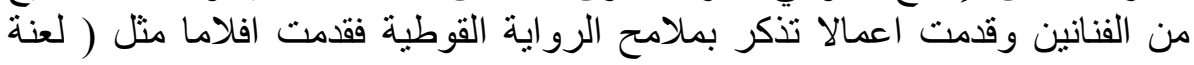

فر انكثتين 1957 (41).

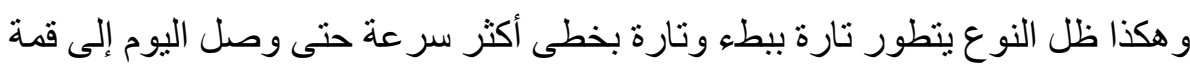

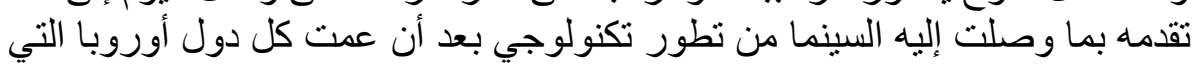


أسست لصناعة سينمائية هائلة أفضت إلى توسع النوع و أزدهاره فترسخت ملامحه

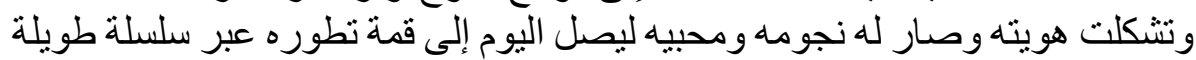

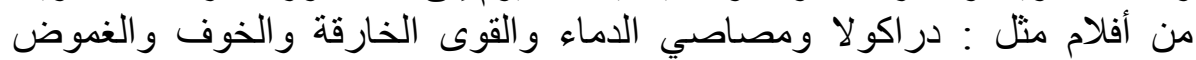
و الأشباح و الثياطين و الوحوش و والمستذئيبين و الخيال العلمي و القتلة المتسلسلين قاطعي الأعناق، وكلها تفر عات متطورة في داخل النوع ذاته والنه (42).

لقد كان وماز ال النوع يحظى بجمهور واسع جدا وأعدادا متز ايدة من المشاهدين

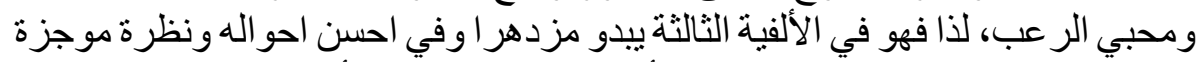

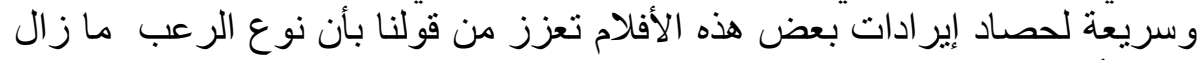

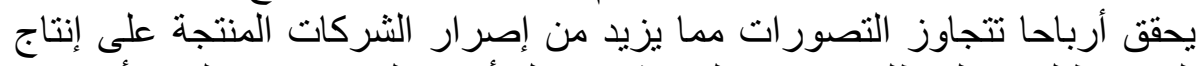

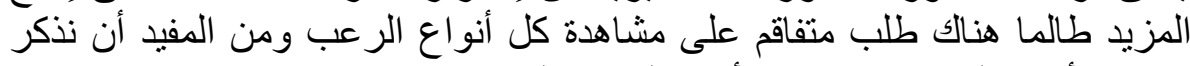

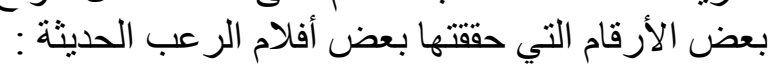

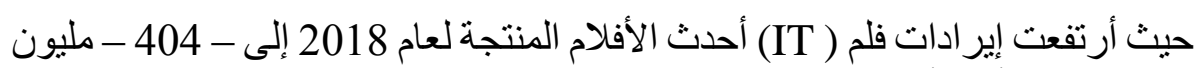

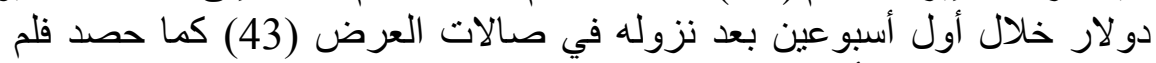

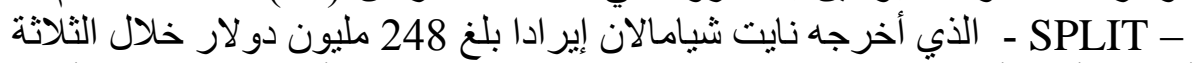

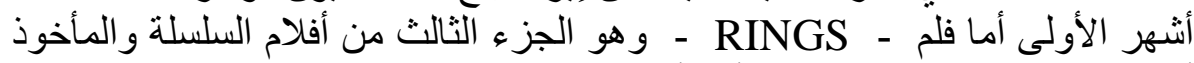

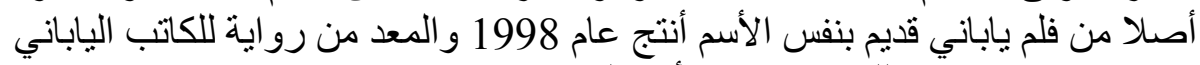

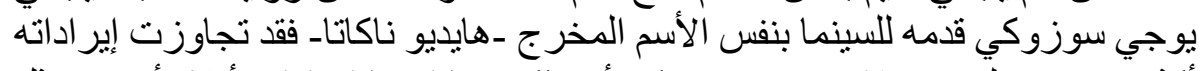

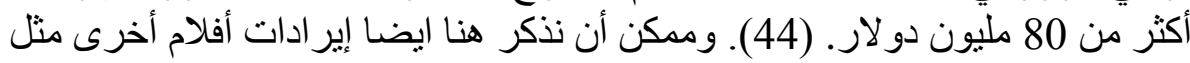

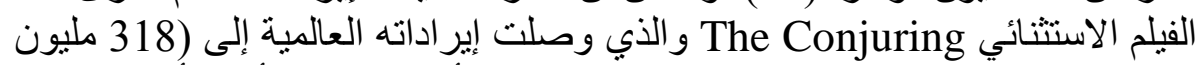

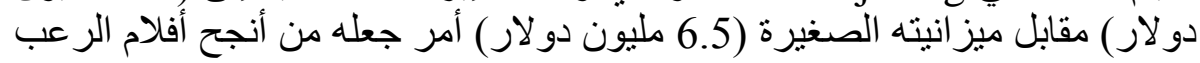
في التاريخ(45) نظر العائداته الكبيرة.

مدخل الاستخدامات والإشباعات :- مئرة

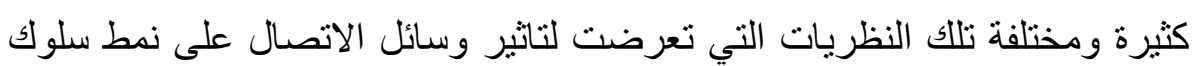

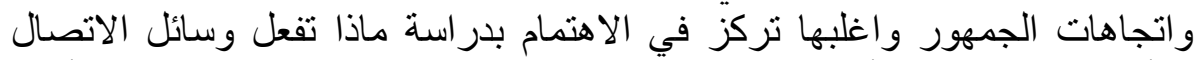

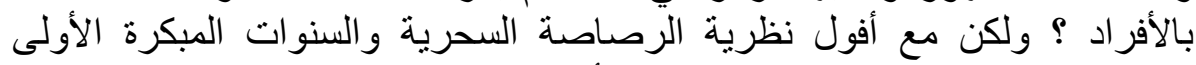

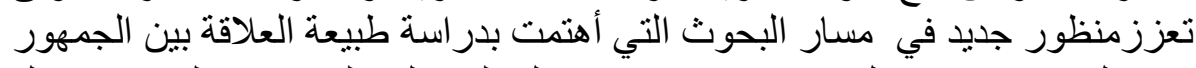

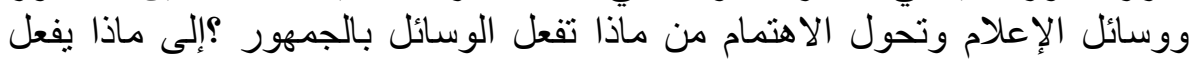

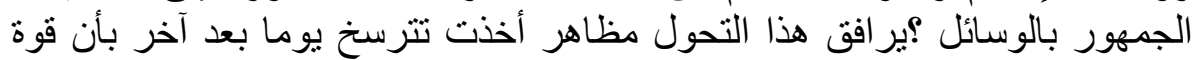

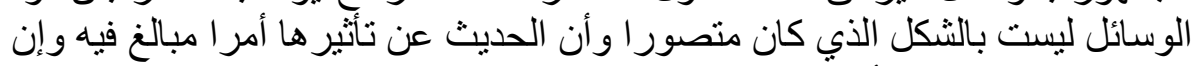

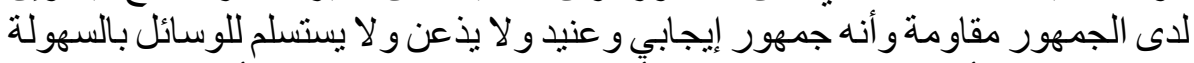

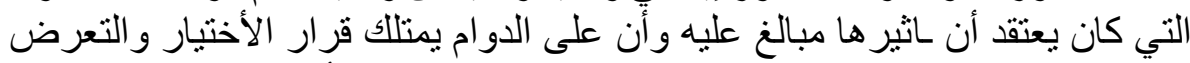

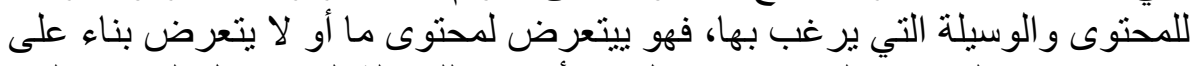

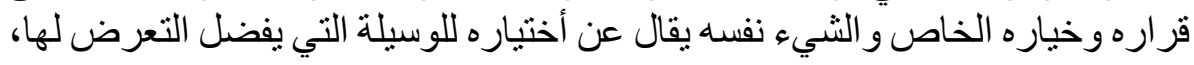




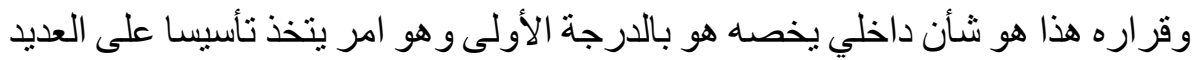

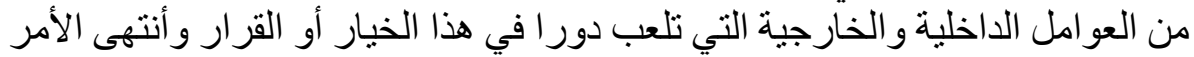

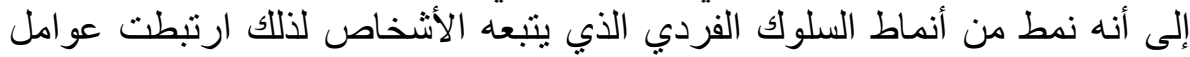

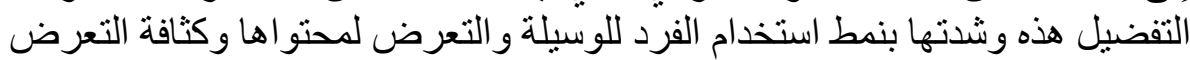

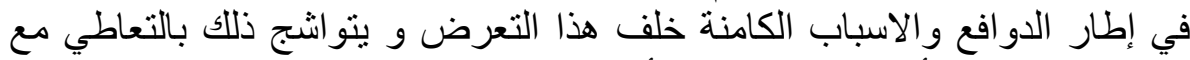

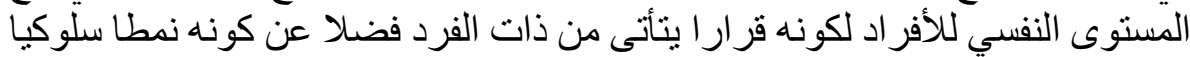

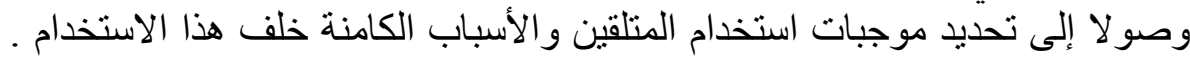

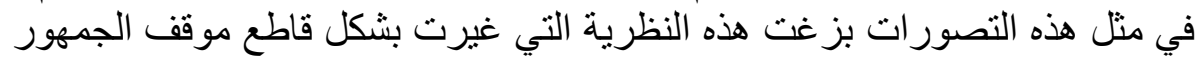

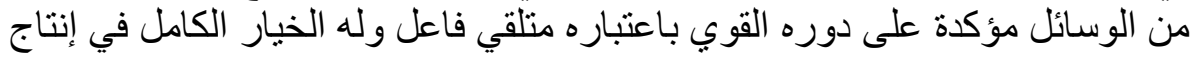

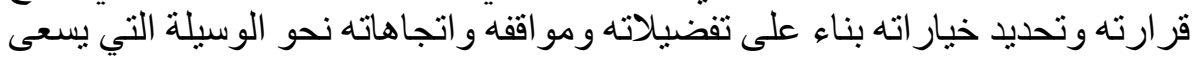

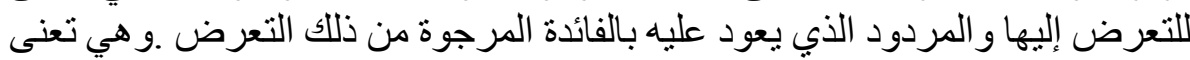

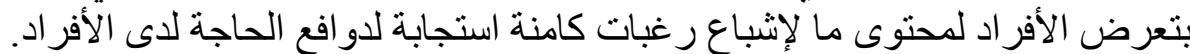

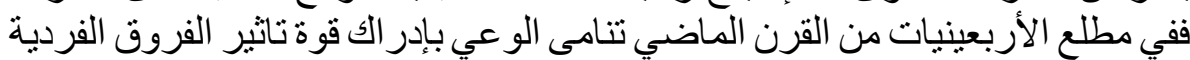

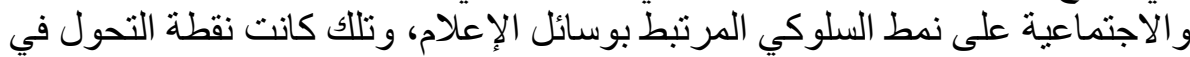

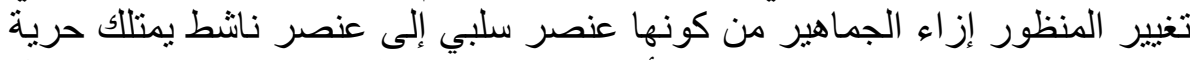

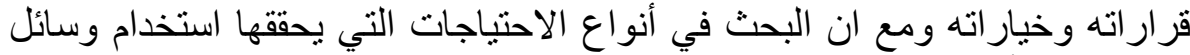

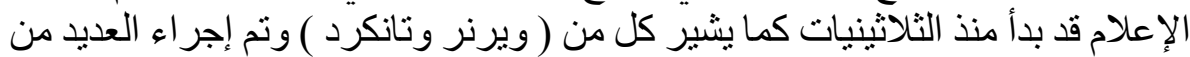

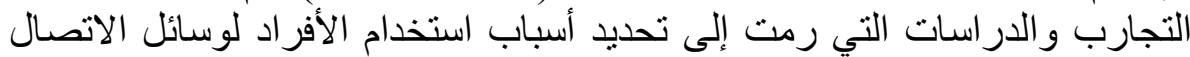

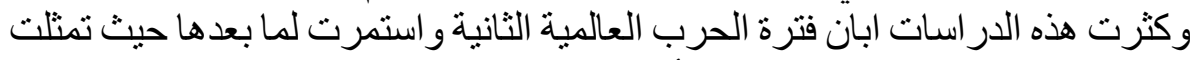

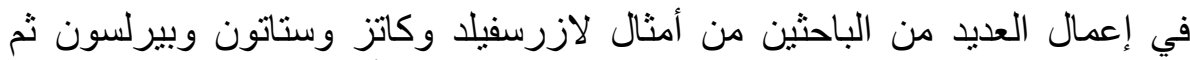

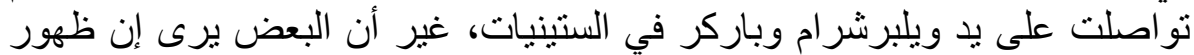

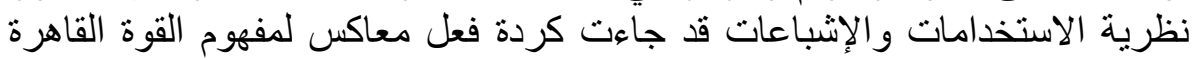

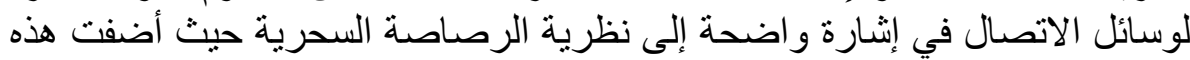

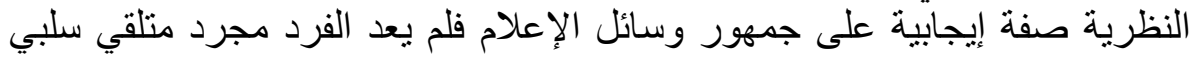

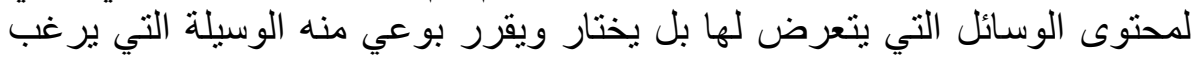

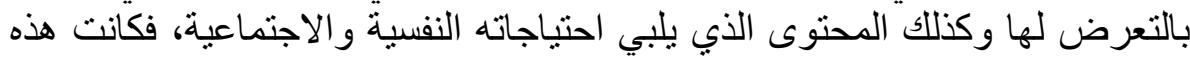

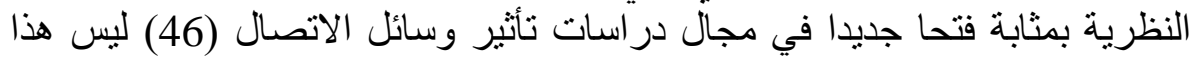

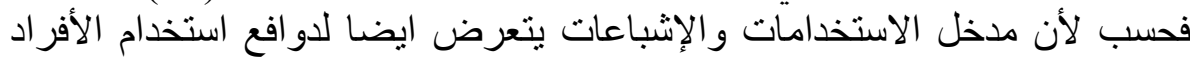

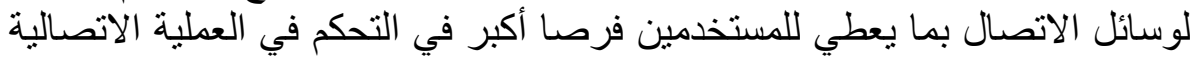

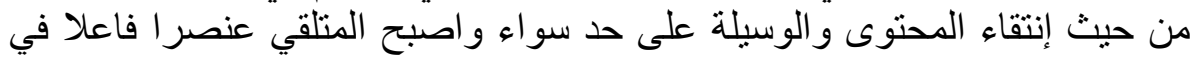

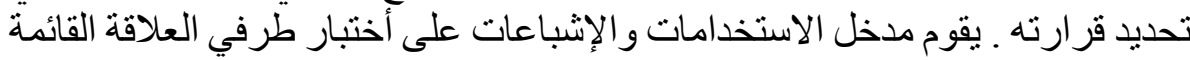

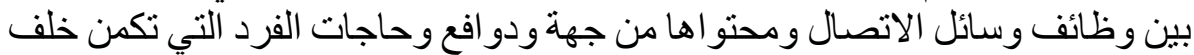

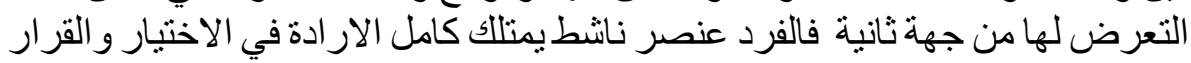

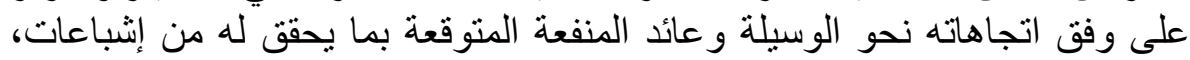

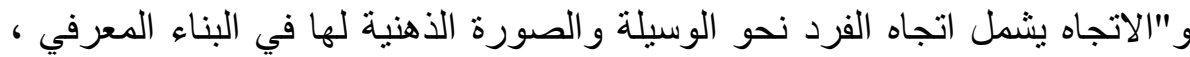


كذلك اتجاهه نحو القائم بالاتصال ثم اتجاهه نحو المتحوى الذي تقدمه هذه الوسيلة وما

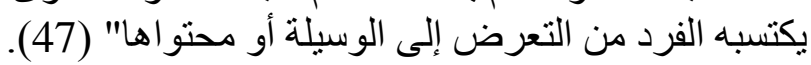

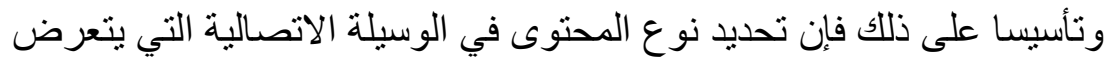

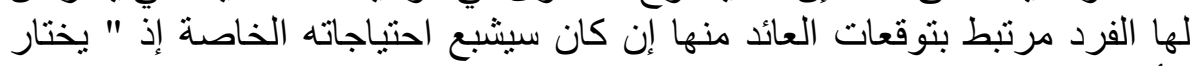

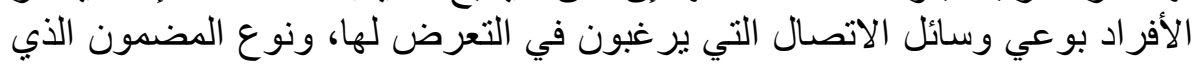

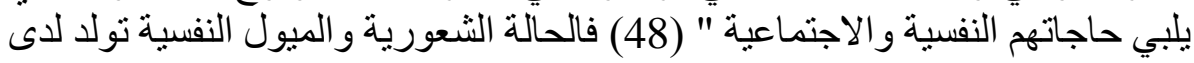

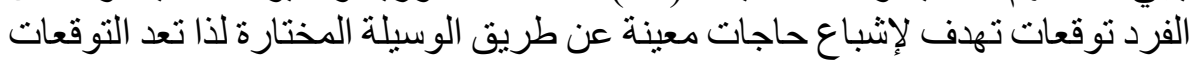

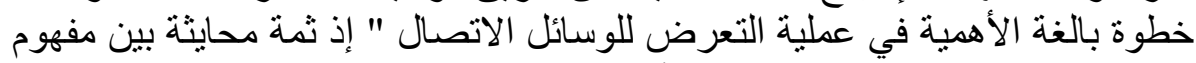

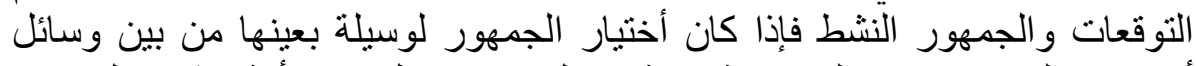

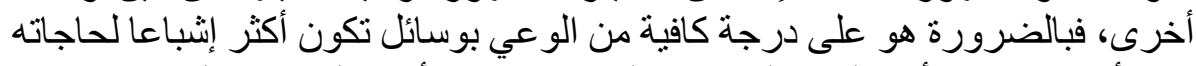

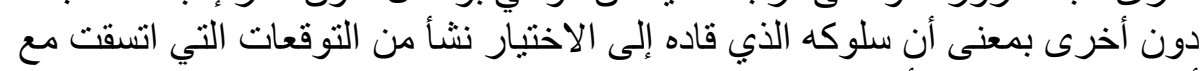

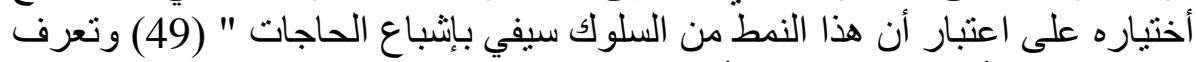

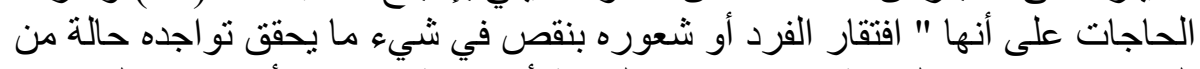

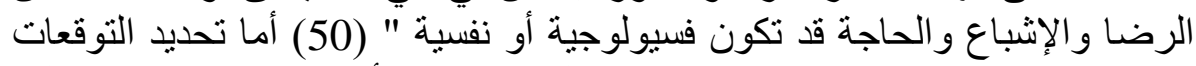

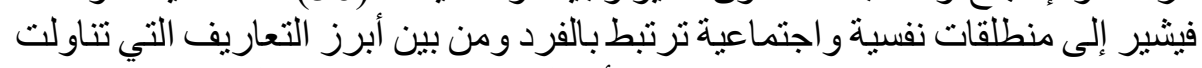

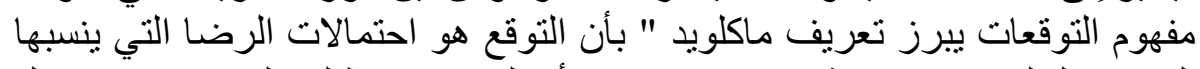

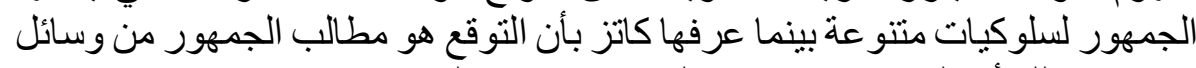
الإعلام،كذلك أن التوقع هو الإشباع الذي يبحث عنه الجمهور "(51).

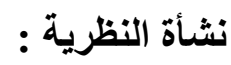

في مطلع الأربعينيات من القرن المنصرم تشكل منظور ا جديدا مُبديا اهنماما منز ايدا

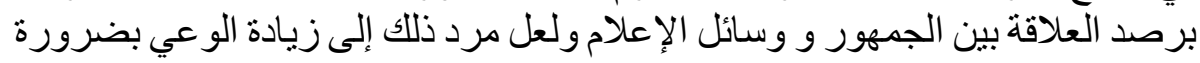

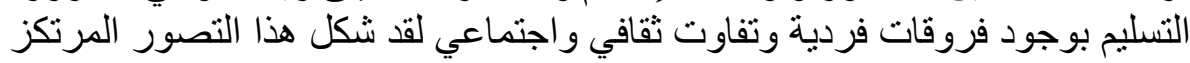

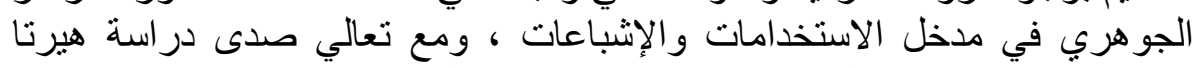

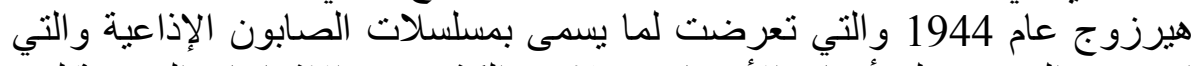

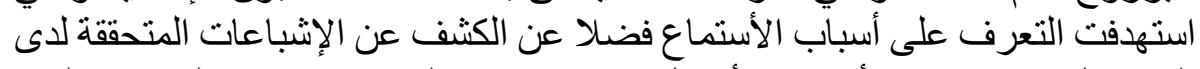

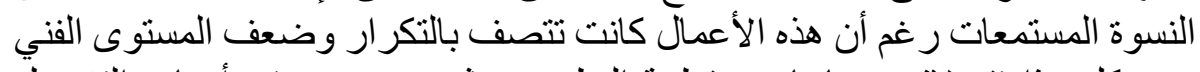

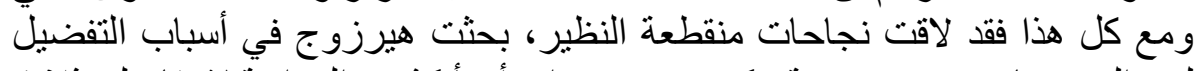

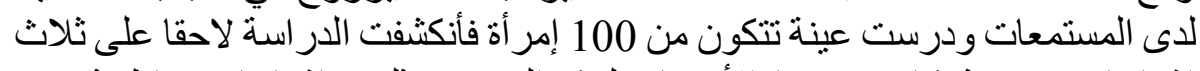

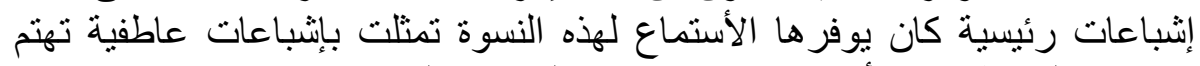

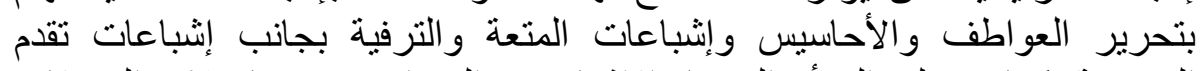

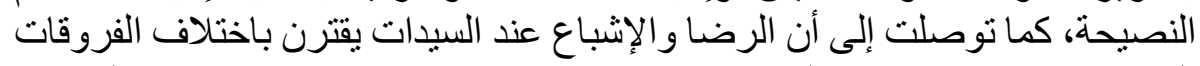

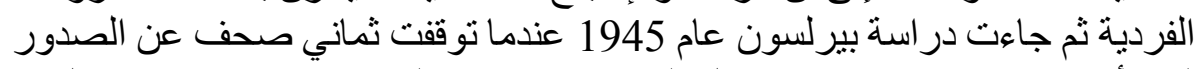

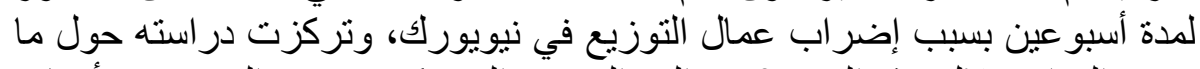

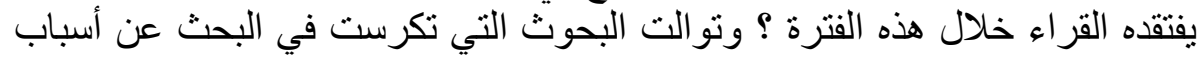




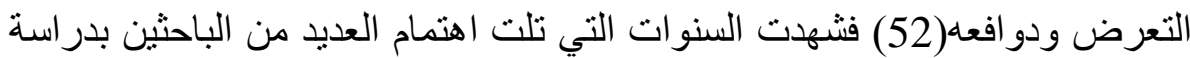

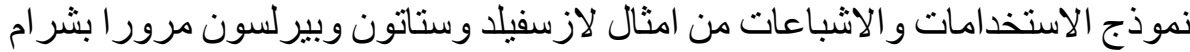

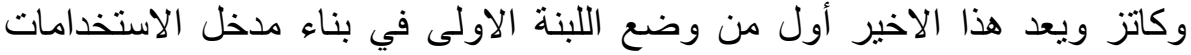

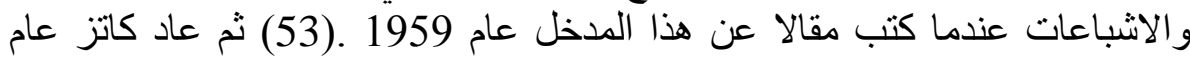

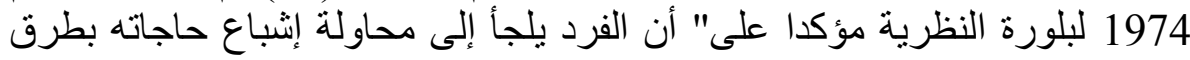

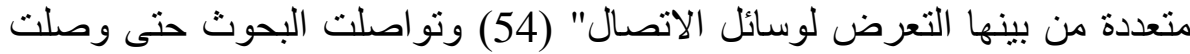

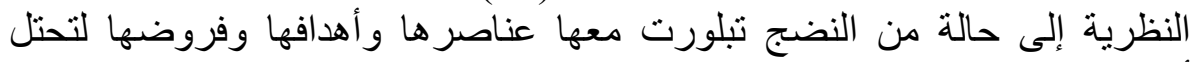
أولويات الدر اسات الاتصالية.

فروض النظرية :- ما أن

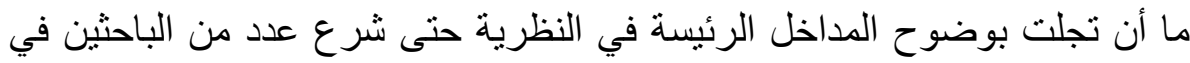

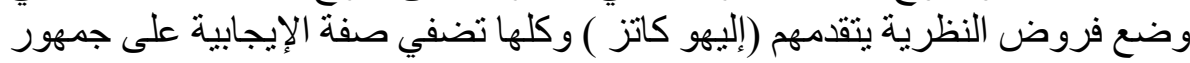

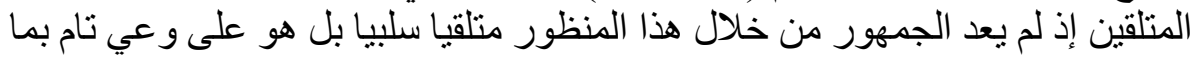

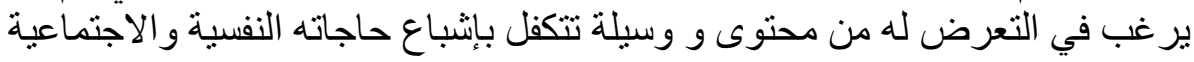

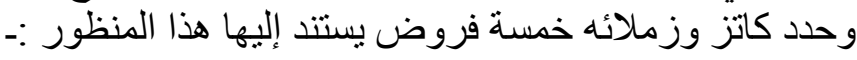

1. إن أعضاء الجمهور مشاركون فعالون في عملية الاتصال الجماهيري

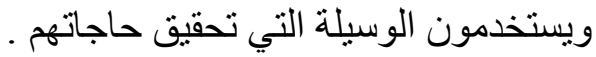

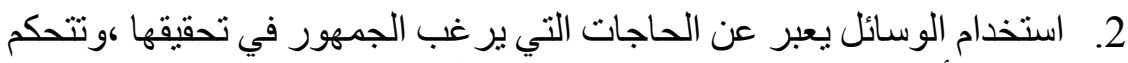
في ذلك أمور منها : الفروق الفردية وانئ التفاعل الاجتماعي .

3. التأكيد على أن الجمهور هو الذي يختار الوسيلة والمضمون اللذين يشبعان

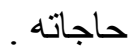

4. يستطيع الجمهور تحديد حاجاته ودوافعها ، ومن ثم يلجأ إلى الوسائل و المضامين التي تشبع حاجاته .

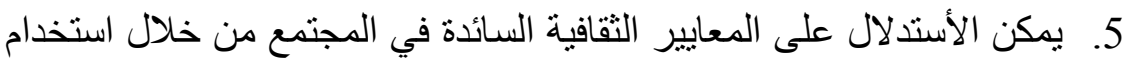

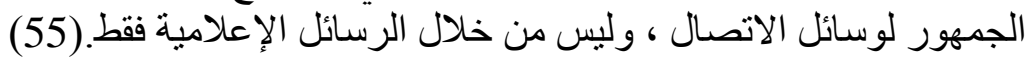

\section{أهمية النظرية بالنسبة للار استة :}

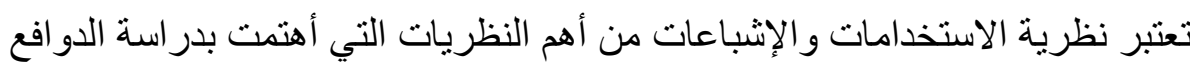

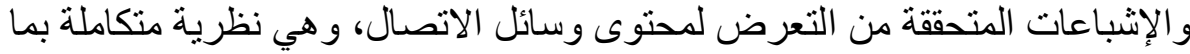

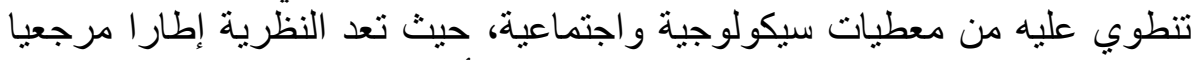

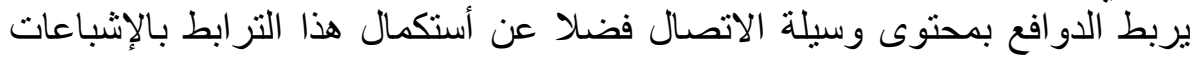
المتحققة من عملية التعرض، كذلك تساعد في فهم جدلية الترابط بين متغير ات عنوال الإن التياعان 


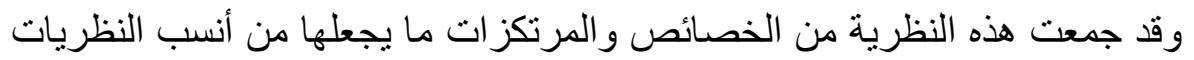

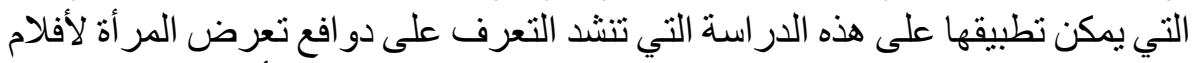

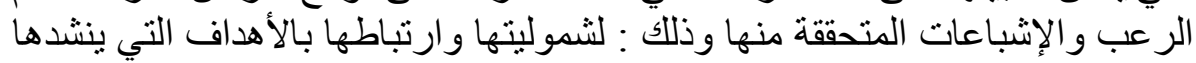

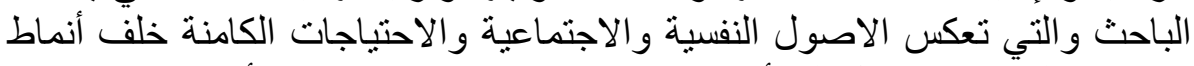

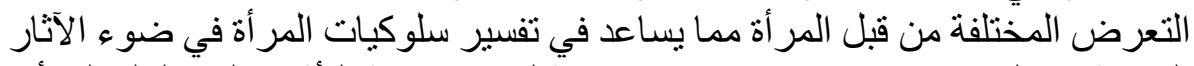

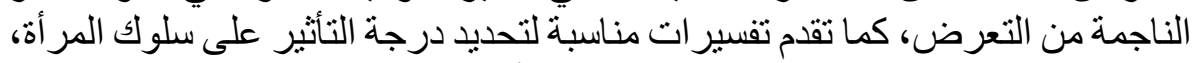

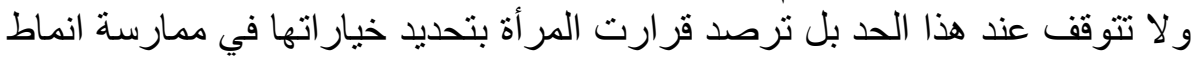

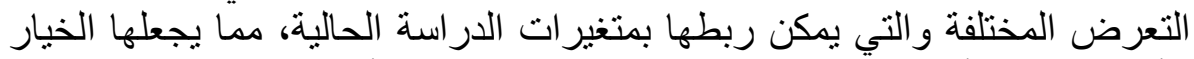

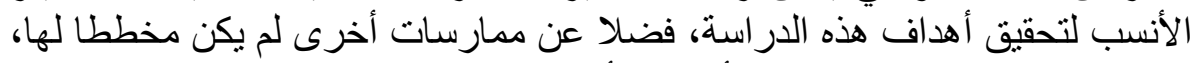

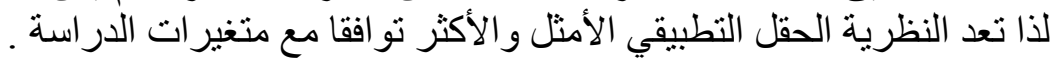

الفصل الثالث نتائج الدراسة الميدانية أولا: خصائص عينة الدراسة

• توزيع العينة حسب متغير العمر

جدول (3): توزيع عينة الدراسة حسب متغير العمر

\begin{tabular}{|c|c|c|}
\hline النسبة المئوية & 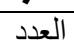 & 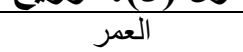 \\
\hline $13.0 \%$ & 13 & من 20 سنة فأقلّ \\
\hline $10.0 \%$ & 10 & من 21 إلى 30 سنة \\
\hline $31.0 \%$ & 31 & من31 إلى 40 سنة \\
\hline $27.0 \%$ & 27 & من41 إلى 50 سنة \\
\hline $19.0 \%$ & 19 & 51 سنة فأكثر \\
\hline $100 \%$ & 100 & المجموع \\
\hline
\end{tabular}

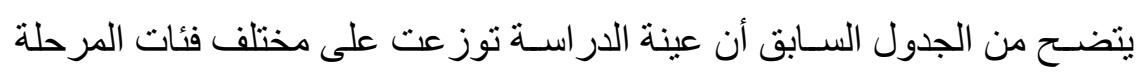

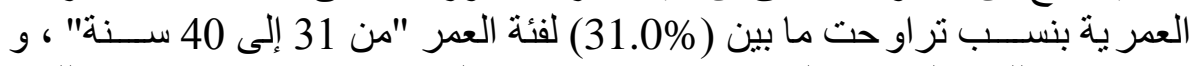

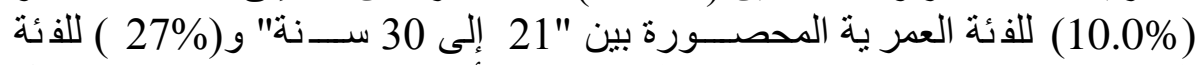

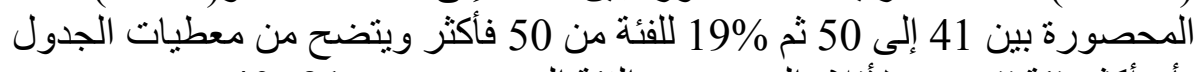

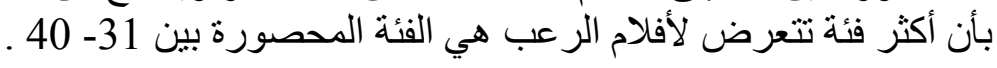

\begin{tabular}{|c|c|c|}
\hline النسبة المئوية التعليمي & العدد & المستوى التعليمي \\
\hline $16.0 \%$ & 16 & ثانوي فأقلَ \\
\hline $9.0 \%$ & 9 & دبلوم \\
\hline $48.0 \%$ & 48 & بكالوريوس \\
\hline $27.0 \%$ & 27 & دراسات عليا \\
\hline $100 \%$ & 100 & المجموع \\
\hline
\end{tabular}




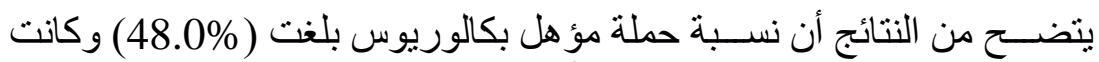

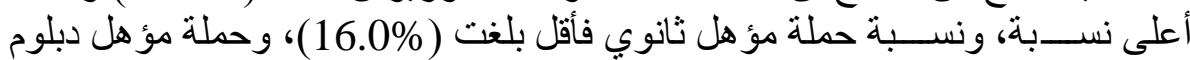
(9.0\%)، وحملة مؤ هل در اسات عليا (27.0\%).

جدول (5): توزيع عينة الدراسة حسب متغير الحالة الاجتماعية

\begin{tabular}{|c|c|c|}
\hline النسبة المئوية & العدد & لحالة الاجتماعية \\
\hline $34.0 \%$ & 34 & غير متزوجه \\
\hline $63.0 \%$ & 63 & متزوجه \\
\hline $2.0 \%$ & 2 & مطلقه \\
\hline $1.0 \%$ & 1 & أرمله \\
\hline $100 \%$ & 100 & المجموع \\
\hline
\end{tabular}

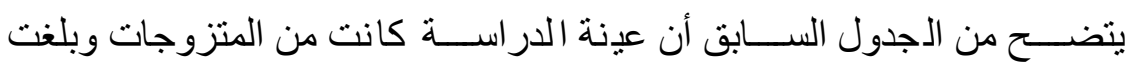

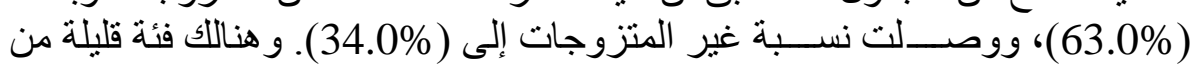

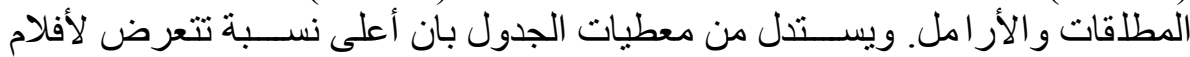

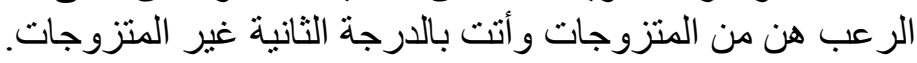

جدول (6): توزيع عينة الدراسة حسب متغير الحالة المهنية

\begin{tabular}{|c|c|c|}
\hline النسبة المئوية & العدد & الحالة المهنية \\
\hline $9.0 \%$ & 9 & طالبة \\
\hline $53.0 \%$ & 53 & موظفه حكومية \\
\hline $21.0 \%$ & 21 & موظفه قطاع خاص \\
\hline $11.0 \%$ & 11 & ربة بيت \\
\hline $6.0 \%$ & 6 & أعمال حرة \\
\hline $100 \%$ & 100 & المجموع \\
\hline
\end{tabular}

يتضح من الجدول السابق أن النسبة الأعلى من عينة الدر اسة كانت من موظفات

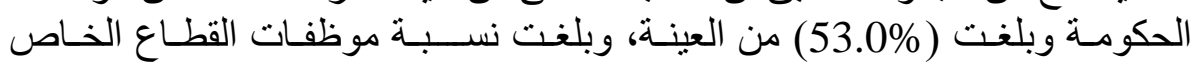

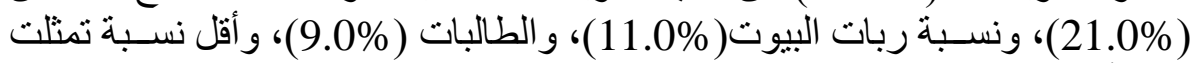
في الأعمال الحرة إذ بلغت (6.0\%).

\begin{tabular}{|c|c|c|}
\hline النسبة المئوية & 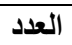 & الجنسية \\
\hline $13.0 \%$ & 13 & أقل من 400 د.ب \\
\hline $37.0 \%$ & 37 & 400ـ أقل من 700 د.ب \\
\hline $42.0 \%$ & 42 & 700 - أقل من 1000 د.ب \\
\hline $8.0 \%$ & 8 & 1000 د.ب فأكثر \\
\hline $100 \%$ & 100 & المجموع \\
\hline
\end{tabular}

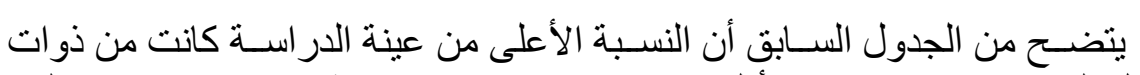

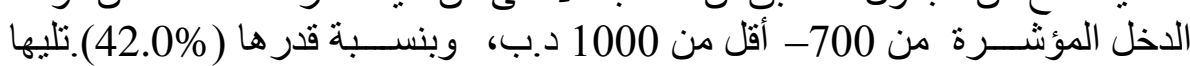


بالدر جة الثاذية الفئة ذات الدخل من 400ـ أ قل من 700 د.ب إذ جاءت بنســبة . (37.0\%)

6. هل أنت شخصية تحب فرض سيطرتها على من معها:

تم حساب التكرارات و النسب المئوية، كما هو موضح في الجدول التالي:

جدول (8): التكرارات والنسب المئوية لمدى حب سيطرة العينة على من معها

\begin{tabular}{|c|c|c|c|}
\hline النسبة المئوية & التكرار & الاستجابة & الرقم \\
\hline $46.0 \%$ & 46 & دائماً & 1 \\
\hline $19.0 \%$ & 19 & أحياناً & 2 \\
\hline $24.0 \%$ & 24 & نادر أ & 3 \\
\hline $11.0 \%$ & 11 & $\gamma$ & 4 \\
\hline $100.0 \%$ & 100 & المجموع & \\
\hline
\end{tabular}

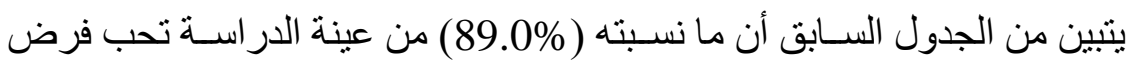

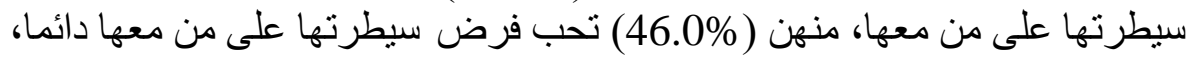

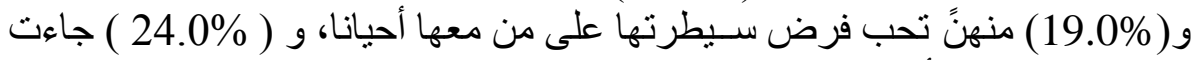

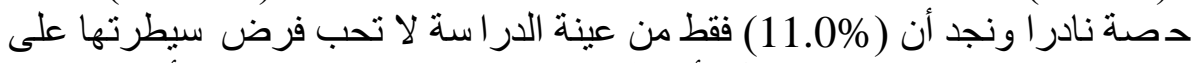

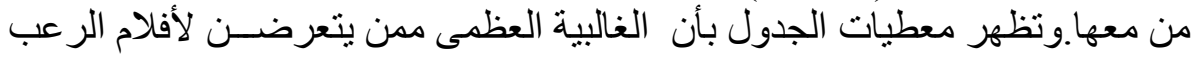

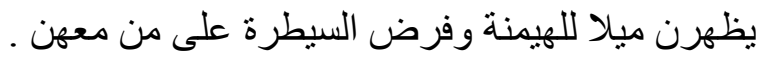

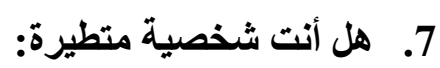

تم حساب التكر ارات و النسب المئوية، كما هو موضح في الجدول التبات التالي: جدول (9): التكرارات والنسب المئوية للشخصية المتطيرة

\begin{tabular}{|c|c|c|c|}
\hline النسبة المئوية & التكرار & الاستجابة & الرقم \\
\hline $13.0 \%$ & 13 & دائماً & 1 \\
\hline $16.0 \%$ & 16 & أحياناً & 2 \\
\hline $18.0 \%$ & 18 & نادر اً & 3 \\
\hline $53.0 \%$ & 53 & $y$ & 4 \\
\hline $100.0 \%$ & 100 & المجموع & \\
\hline
\end{tabular}

تظهر نتائج الجدول السابق أن ما ذسبته (47.0\%) من عينة النساء بعتقدن بأنهن

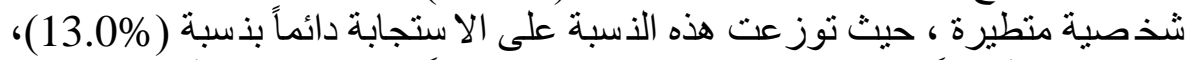

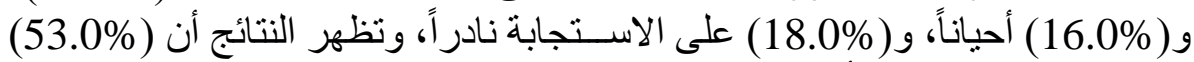

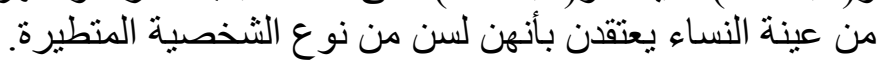

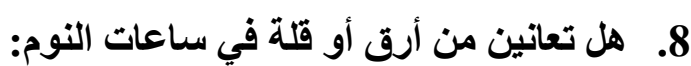

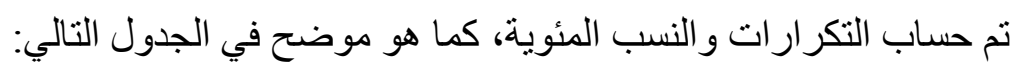


جدول (10): التكرارات والنسب المئوية لمدى معاناة العينة من أرق أو قلة في ساعات النوم

\begin{tabular}{|c|c|c|c|}
\hline النسبة المئوية & التكرار & الاستجابة & الرقم \\
\hline $59.0 \%$ & 59 & دائماً & 1 \\
\hline $26.0 \%$ & 26 & أحياناً & 2 \\
\hline $8.0 \%$ & 8 & نادر أ & 3 \\
\hline $7.0 \%$ & 7 & $\bar{\gamma}$ & 4 \\
\hline $100.0 \%$ & 100 & المجموع & \\
\hline
\end{tabular}

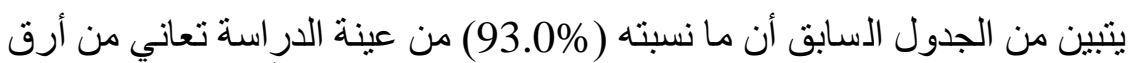

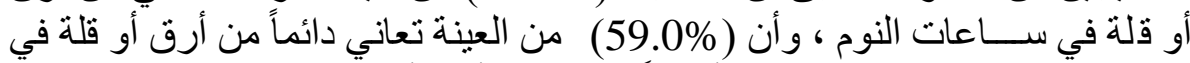

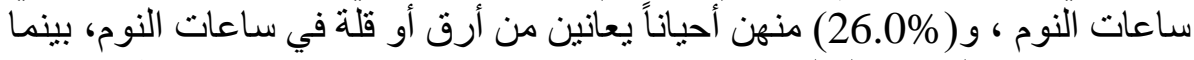

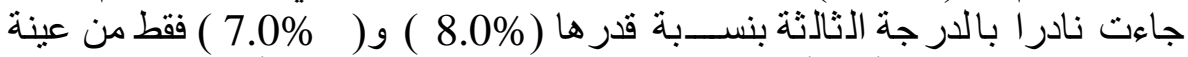

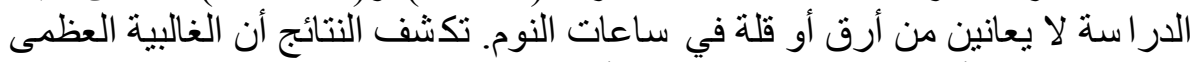

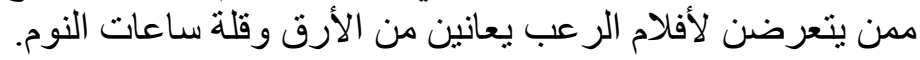

$$
9 \text {. هل أنت ممن لايهن قدرة كبيرة على التخيل: }
$$

تم حساب التكرارات و النسب المئوية، كما هو موضح في الجدول التالي:

\begin{tabular}{|c|c|c|c|}
\hline النسبة المئوية & التكرار & الاستجابة & الرقم \\
\hline $21.0 \%$ & 21 & $2^{2}$ & 1 \\
\hline $51.0 \%$ & 51 & لى لى حذٍ ما & 2 \\
\hline $28.0 \%$ & 28 & 2 & 3 \\
\hline $100.0 \%$ & 100 & المجموع & \\
\hline
\end{tabular}

تظهر نتائج الجدول السابق أن العينة تتمتع بقدرة عالية على التخيل بحيث أكدت

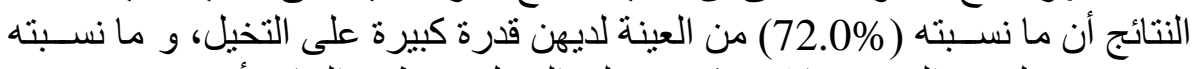
(51.0\%) لديهن الى حدٍ ما قدرة كبيرة على التخيل، وتظهر النتائج أن (

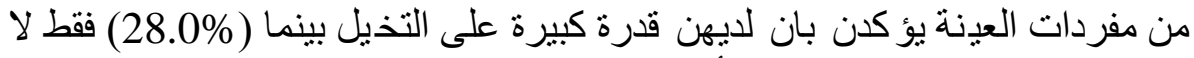

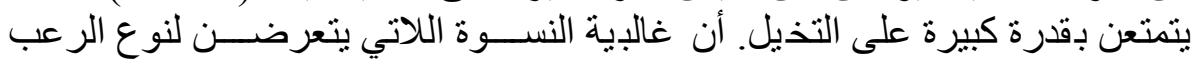

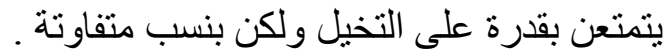

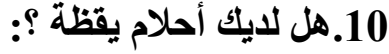

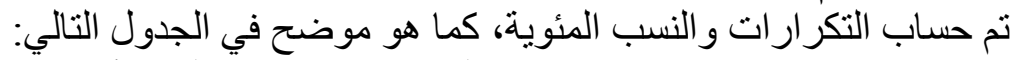

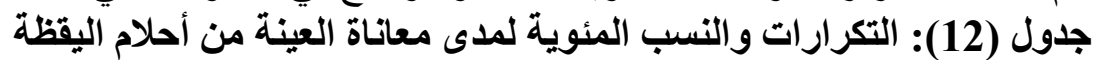

\begin{tabular}{|c|c|c|c|}
\hline النسبة المئوية & التكرار & الاستجابة & الرقم \\
\hline $11.0 \%$ & 11 & دائماً & 1 \\
\hline $17.0 \%$ & 17 & أحياناً & 2 \\
\hline $16.0 \%$ & 16 & نادراً & 3 \\
\hline $56.0 \%$ & 56 & $y$ & 3 \\
\hline $100.0 \%$ & 100 & المجموع & \\
\hline
\end{tabular}


يتبين من الجدول السـابق أن ما نسـبته (44.0\%) من عينة الدر اسـة لديهن أحلام

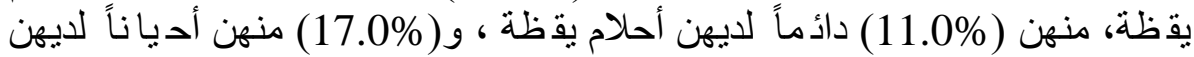

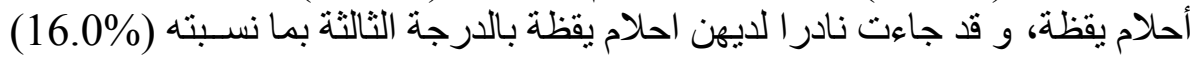

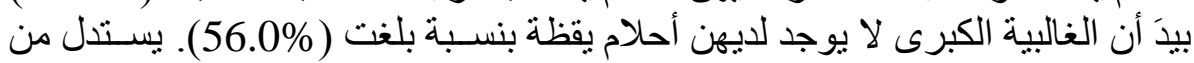

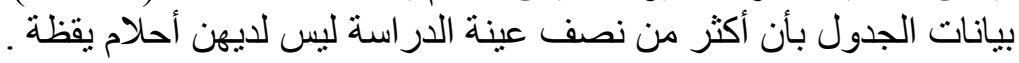

\section{1 ـ برأيك هل تعاني المرأة من الاحباط: بان بان}

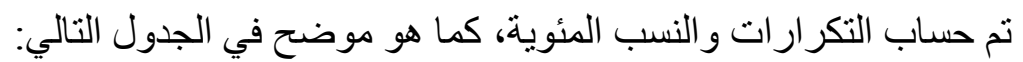

جدول (13): التكرارات و النسب المئوية لمدى معاناة المرأة من الاحباط

\begin{tabular}{|c|c|c|c|}
\hline النسبة المئوية & التكرار & الاستجابة & الرقم - ل الرق \\
\hline $34.0 \%$ & 34 & دائماً & 1 \\
\hline $17.0 \%$ & 17 & أحياناً & 2 \\
\hline $15.0 \%$ & 15 & نادراً & 3 \\
\hline $36.0 \%$ & 36 & $\gamma$ & 3 \\
\hline $100.0 \%$ & 100 & المجموع & \\
\hline
\end{tabular}

تظهر نتائج الجدول الاسابق أن ذسبة اللاتي يعانين من الإحباط عالية بين النسـوة

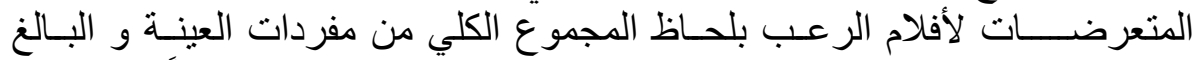

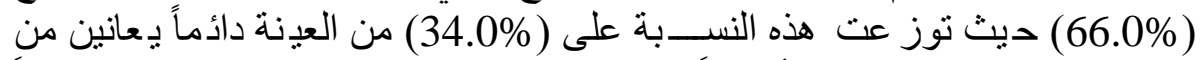

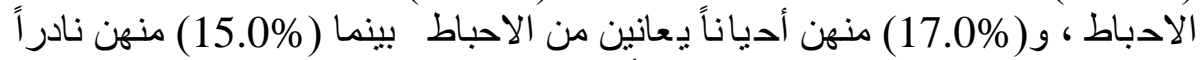

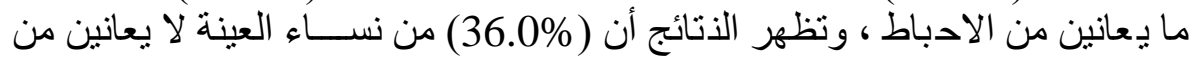

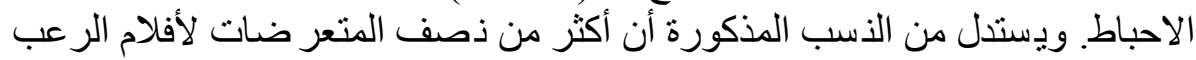
يعانين من الإحباط بدرجات متفاونة.

\section{2 ـهل أنت مستعدة لمواجهة المشكلات التي تؤرقك:}

تم حساب التكرارات و النسب المئوية، كما هو موضح في الجدول التالي:

جدول (14): التكرارات والنسب المئوية لمدى استعداد العينة لمواجهة المشكلات

$$
\text { التي تؤرقها }
$$

\begin{tabular}{|c|c|c|c|}
\hline النسبة المئوية & التكرار & الاستجابة & الرقم \\
\hline $36.0 \%$ & 36 & دائماً & 1 \\
\hline $24.0 \%$ & 24 & أحياناً & 2 \\
\hline $16.0 \%$ & 16 & نادر أ & 3 \\
\hline $24.0 \%$ & 24 & $\gamma$ & 3 \\
\hline $100.0 \%$ & 100 & المجموع & \\
\hline
\end{tabular}




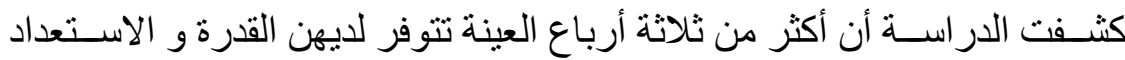

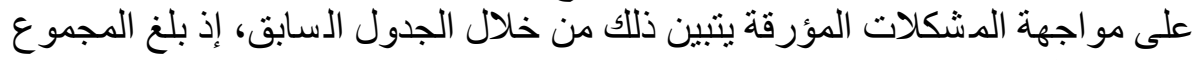

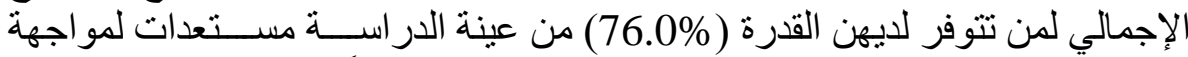

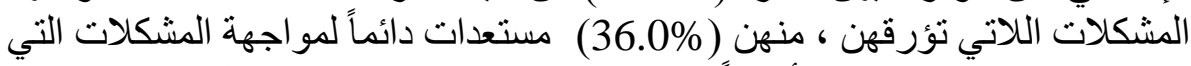

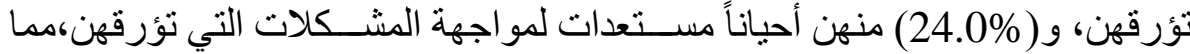

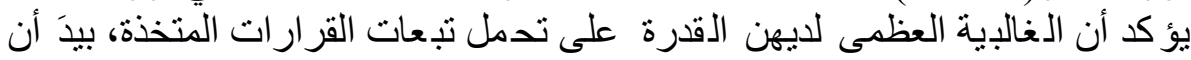

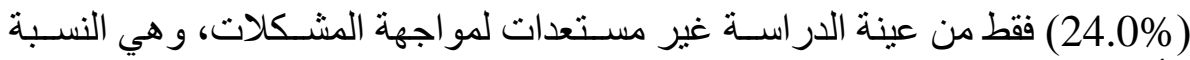
الأصغر.

13. عندما تختلفين مع الأصدقاء هل تلجئين إلى (يمكن اختيار أكثر من بديل): تم حساب التكرارات و النسب المئوية، كما هو موضح في الجدول التئين التالي: جدول (15): التكرارات والنسب المئوية لكيفية تصرف العينة عند الاختلاف مع الاصدقاء

\begin{tabular}{|c|c|c|c|}
\hline النسبة المئوية & التكرار & الاستجابة & أرق \\
\hline $27.0 \%$ & 27 & التودد & 1 \\
\hline $56.0 \%$ & 56 & التشدد & 2 \\
\hline $7.0 \%$ & 7 & الانطواء & 3 \\
\hline $9.0 \%$ & 9 & البكاء & 4 \\
\hline $11.0 \%$ & 11 & التو عد بالانتقام & 5 \\
\hline $6.0 \%$ & 6 & المقاطعة & 6 \\
\hline $12.0 \%$ & 12 & الرضوخ & 7 \\
\hline $6.0 \%$ & 6 & اعتداء فعلي & 8 \\
\hline $29.0 \%$ & 29 & اعتداء لفظي & 9 \\
\hline $31.0 \%$ & 31 & التأنيب & 10 \\
\hline $4.0 \%$ & 4 & تتمنين ان يلحق بهم الاذى & 11 \\
\hline $18.0 \%$ & 18 & التنسامح & 12 \\
\hline
\end{tabular}

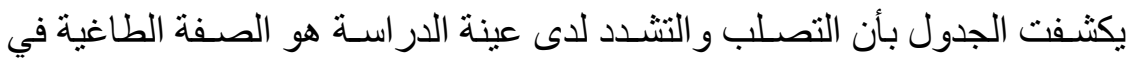

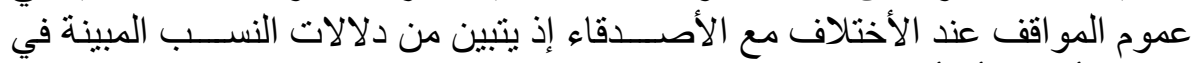

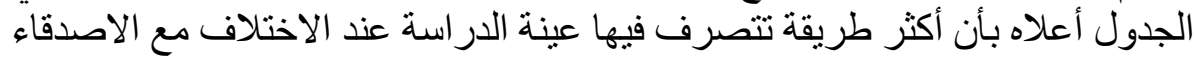

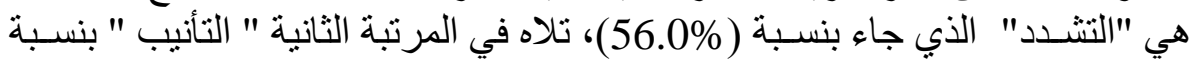

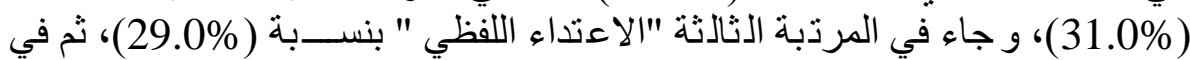

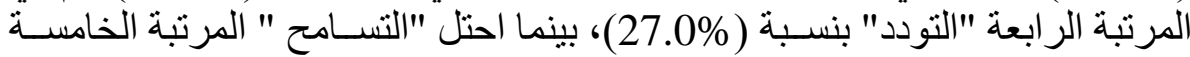

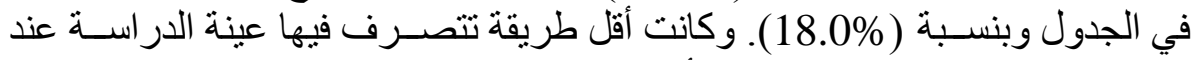
الاختنلاف مع الاصدقاء هي "تتمنى أن يلحق بهم الاذى " بنسبة (4.0\%) (4.0\%)، ثم " اعتداء فعلي " بنسبة (6.0\%).

14 ـ عند تعرضك للانتقاد من الآخرين هل تلجئين (يمكن اختيار أكثر من بديل): تم حساب التكر ارات و النسب المئوية، كما هو موضح في الجدول التالي: 
جدول (16): التكرارات والنسب المئوية لكيفية تصرف العينة عند تعرضها للانتقاد

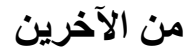

\begin{tabular}{|c|c|c|c|}
\hline النسبة المئوية & التكرار & الاستجابة & الرقم \\
\hline $37.0 \%$ & 37 & الأنكار & 1 \\
\hline $29.0 \%$ & 29 & التبرير & 2 \\
\hline $9.0 \%$ & 9 & جلد الذات & 3 \\
\hline $11.0 \%$ & 11 & الخوف & 4 \\
\hline $31.0 \%$ & 31 & القلق & 5 \\
\hline $34.0 \%$ & 34 & الإحباط & 6 \\
\hline $48.0 \%$ & 48 & الرد بقوة & 7 \\
\hline $14.0 \%$ & 14 & الخجل & 8 \\
\hline $19.0 \%$ & 19 & إظهار سلوك خشن & 9 \\
\hline $7.0 \%$ & 7 & التقليل من ذاتك & 10 \\
\hline $4.0 \%$ & 4 & العزلة و الانطواء & 11 \\
\hline $23.0 \%$ & 23 & احتر ام رأي المنتقد & 12 \\
\hline $22.0 \%$ & 22 & الإعراب عن الامتتان & 13 \\
\hline
\end{tabular}

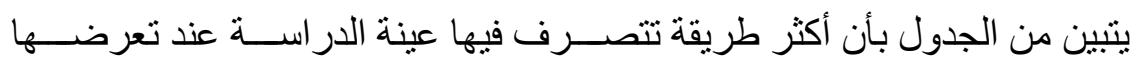

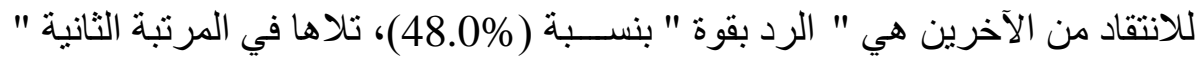

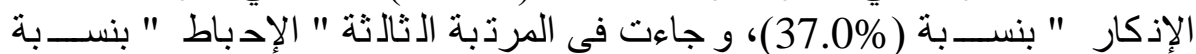

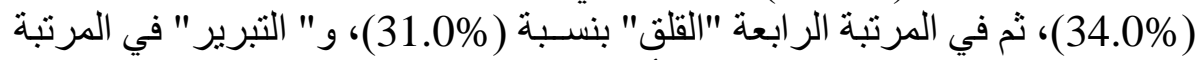

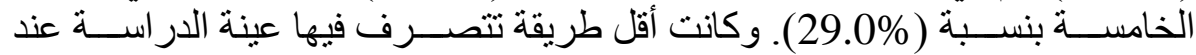
تعرضـها للانتقاد من الآخرين هي " العزلة و الانطو اء " بنسـبة (4.0\%)، ثم " التقليل

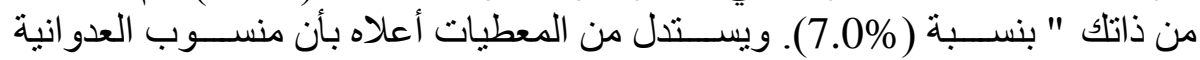

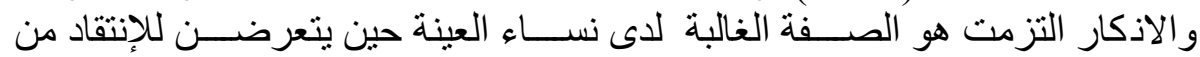
15 هل تخافين من الأمكنة التالية (يمكن اختيار أكثر من بديل):

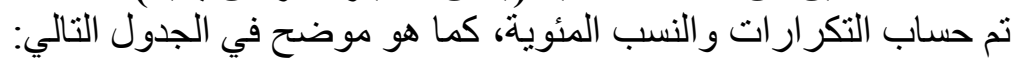
جدول (17): التكرارات والنسب المئوية لمدى خوف العينة من بعض الأماكن

\begin{tabular}{|c|c|c|c|}
\hline النسبة المئوية & التكرار & الاستجابة & الرق \\
\hline $51.0 \%$ & 51 & المنعزلة & 1 \\
\hline $63.0 \%$ & 63 & المظلمة & 2 \\
\hline $15.0 \%$ & 15 & المليئة بالظلال & 3 \\
\hline $3.0 \%$ & 3 & ذات الزو ايا الحادة & 4 \\
\hline $22.0 \%$ & 22 & القديمة & 5 \\
\hline $5.0 \%$ & 5 & ذات الألو ان الكالحة & 6 \\
\hline $6.0 \%$ & 6 & المنفتحة ( غبر محددة جغر افيا ) & 7 \\
\hline $19.0 \%$ & 19 & الضيقة & 8 \\
\hline $60.0 \%$ & 60 & غبر المأهولة & 9 \\
\hline $61.0 \%$ & 61 & الأقبية & 10 \\
\hline
\end{tabular}




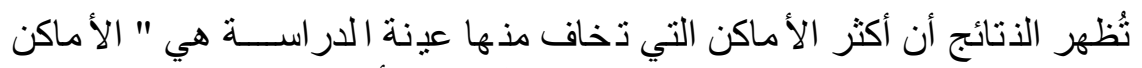

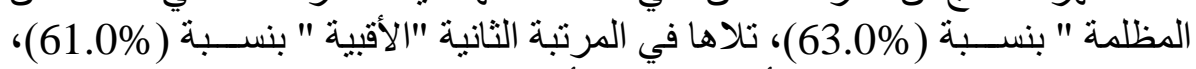

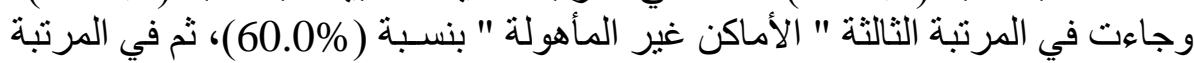

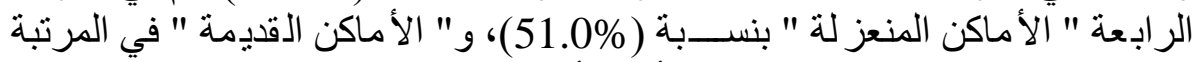

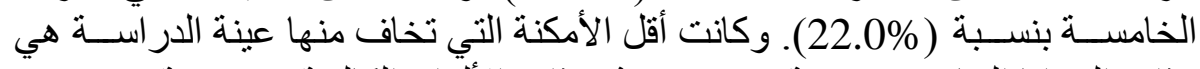

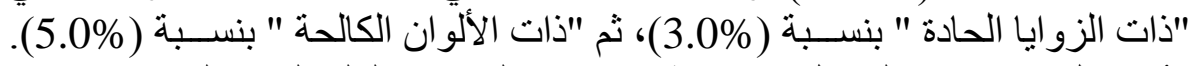

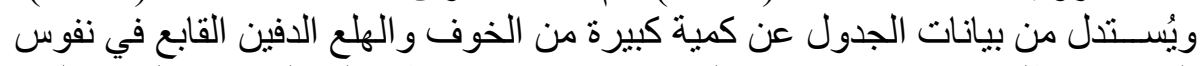

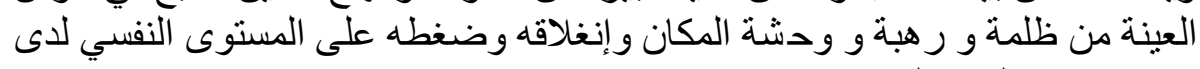

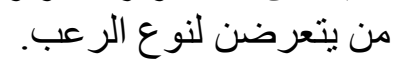

\section{6 ـ مدى معاناة الجو الأسري داخل العائلة من المشاكل:}

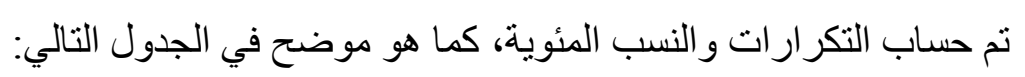
جدول (18): التكرارات والنسب المئوية لمدى معاناة الجو الأسري داخل العائلة من المشاكل

\begin{tabular}{|c|c|c|c|}
\hline النسبة المئوية & 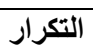 & الاستجابة & الرقق \\
\hline $24.0 \%$ & 24 & كان يعاني من مشاكل & 1 \\
\hline $37.0 \%$ & 37 & ما زال يعاني من مشاكل & 2 \\
\hline $39.0 \%$ & 39 & لا يعاني من مشاكل & 3 \\
\hline $100.0 \%$ & 100 & المجموع & \\
\hline
\end{tabular}

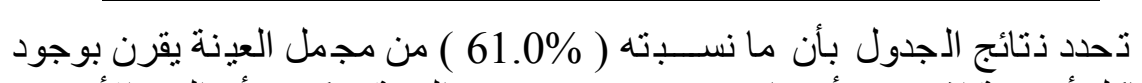

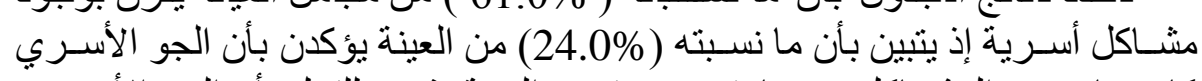

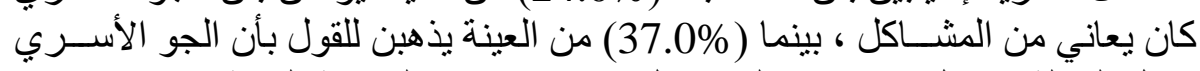

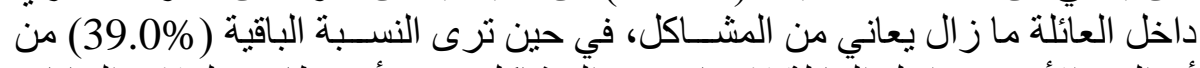

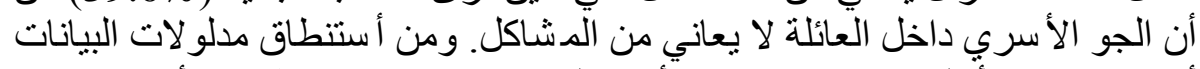

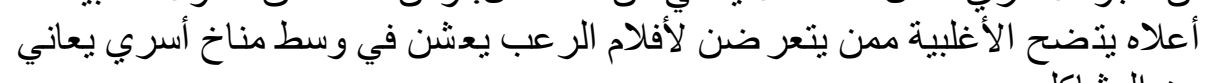
من المشاكل. (1اهن. 


\section{7 ـ مكانة المرأة في داخل الأسرة:}

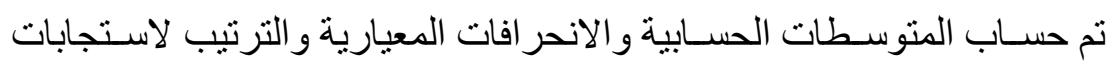
العينة، كما هو موضح في الجدول التالي: جدول (19): المتوسطات الحسابية والاتحرافات المعيارية والترتيب لمكانة المرأة في داخل الأسرة

\begin{tabular}{|c|c|c|c|c|c|}
\hline 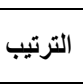 & الانحرافاتة & الأهمبية & 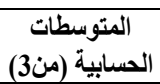 & 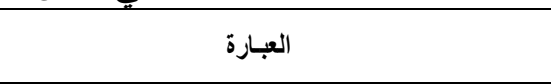 & 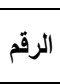 \\
\hline 1 & 0.515 & $92.0 \%$ & 2.760 & تحرص الأسرة على دعم قرارات المر أة باستمر ار & 16 \\
\hline 2 & 0.584 & $87.0 \%$ & 2.610 & يعول على رأيها كثير اويعتد به & 14 \\
\hline 3 & 0.586 & $86.7 \%$ & 2.600 & تشارك في وضع القرار ات المهمة ذات الصلة بشؤون الأسرة & 13 \\
\hline 4 & 0.574 & $85.3 \%$ & 2.560 & أن لها مكانة اعتبارية محترمة جداً & 9 \\
\hline 5 & 0.674 & $83.7 \%$ & 2.510 & أنها حرة في اتخاذ ما تر اه مناسبا لها & 15 \\
\hline 6 & 0.609 & $78.3 \%$ & 2.350 & هي دائما موضع ثقة واعتزاز & 12 \\
\hline 7 & 0.677 & $77.0 \%$ & 2.310 & لها حضور مميز في داخل الأسرة & 10 \\
\hline 8 & 0.677 & $69.3 \%$ & 2.080 & في داخل الأسرة يعتمد عليها في كل شيء & 8 \\
\hline 9 & 0.770 & $68.3 \%$ & 2.050 & لا لتشارك في صنع القرار ات المهمة داخل الأسرة & 7 \\
\hline 10 & 0.725 & $66.7 \%$ & 2.000 & تحتل المكانة التي تحب أن تكون فيها & 11 \\
\hline 11 & 0.683 & $57.3 \%$ & 1.720 & تشتعر بأنها تعامل بتعنف & 3 \\
\hline 12 & 0.427 & $54.7 \%$ & 1.640 & تشتعر بأنها شخصبة مسلوبة الإرادة & 2 \\
\hline 13 & 0.659 & $50.3 \%$ & 1.510 & لا تقدر كما يجب & 5 \\
\hline 14 & 0.566 & $49.0 \%$ & 1.470 & لا أحد يقيم لر أيها وزنأً & 4 \\
\hline 15 & 0.626 & $48.7 \%$ & 1.460 & لا يرون فيها شخصية تتمتع بقدرات ومؤهلات قوية & 6 \\
\hline 16 & 0.742 & $48.0 \%$ & 1.440 & تشتعر المر أة داخل الأسرة بأنها مضطهةة & 1 \\
\hline
\end{tabular}

تظهر نتائج الجدول السابق أن أكثر عبارة تعبر عن مكانة المرأة في داخل الأسرة هي "الأنا

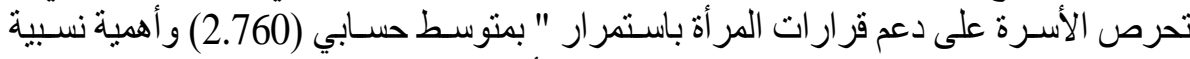

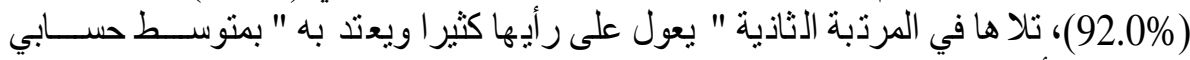

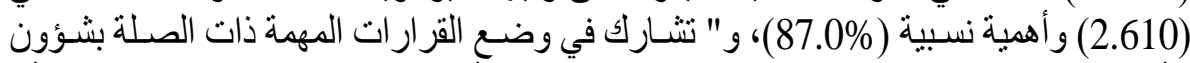

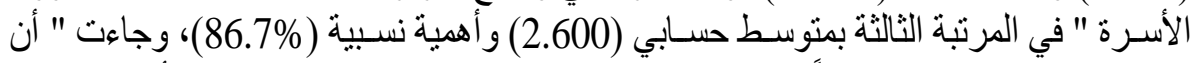

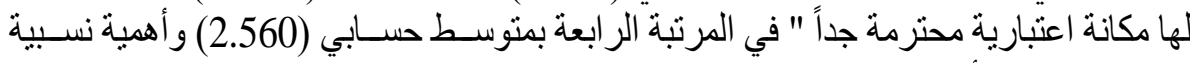

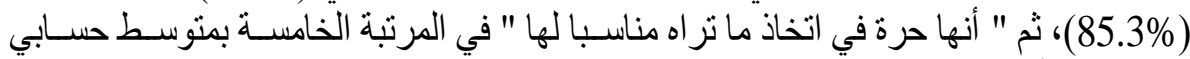

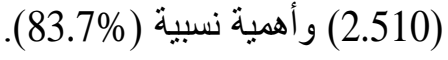

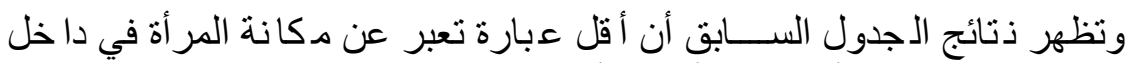

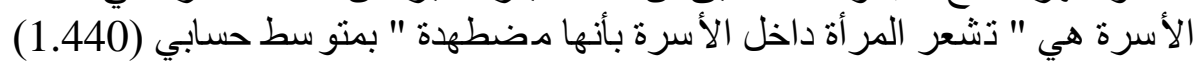

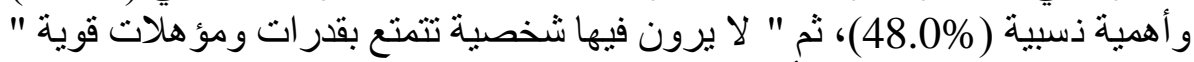

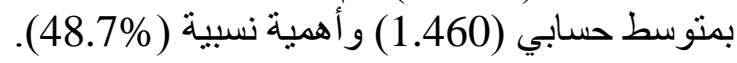

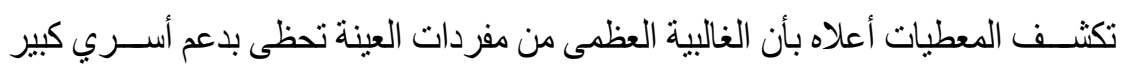

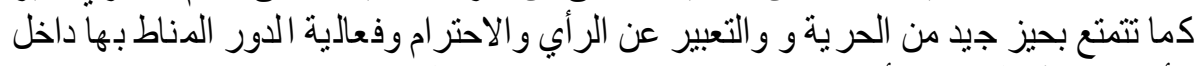

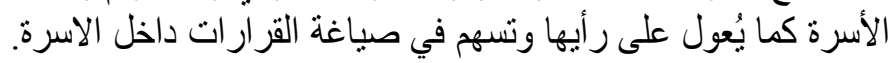




\section{8 ـ هل أنت شخصية تفضل العزلة؟}

تم حساب التكرارات والنسب المئوية، كما هو موضح في الجدول التالي:

جدول (20): التكرارات والنسب المئوية لمدى تفضيل العينة العزلة العية

\begin{tabular}{|c|c|c|c|}
\hline النسبة المئوية & التكرار & الاستجابة & الرقم - ل الرق \\
\hline $37.0 \%$ & 63 & 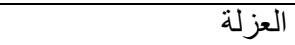 & 1 \\
\hline $63.0 \%$ & 37 & الاختلاط بالآخرين & 2 \\
\hline $100.0 \%$ & 100 & المجموع المجوع & \\
\hline
\end{tabular}

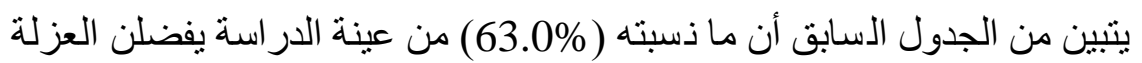

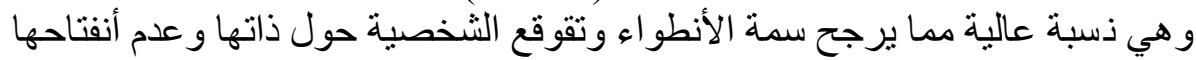

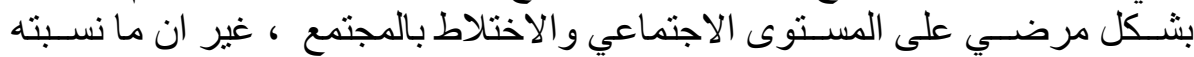
(37.0\%) يفضلن الاختلاط بالآخرين.

19 هل تشاهدين أفلام الرعب ؟

تم حساب التكرارات و النسب المئوية، كما هو موضح في الجدول التالي:

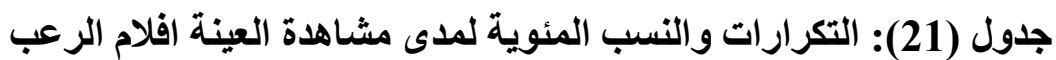

\begin{tabular}{|c|c|c|c|}
\hline النسبة المئوية & التكرار & الاستجابة & الرقم \\
\hline $59.0 \%$ & 59 & ائماً & 1 \\
\hline $24.0 \%$ & 24 & حياناً & 2 \\
\hline $17.0 \%$ & 17 & ادراً & 3 \\
\hline $100.0 \%$ & 100 & المجموع & \\
\hline
\end{tabular}

تظهر نتائج الجدول السابق أن ما ذسبته (59.0\%) من العينة دائماً يشاهدن أفلام

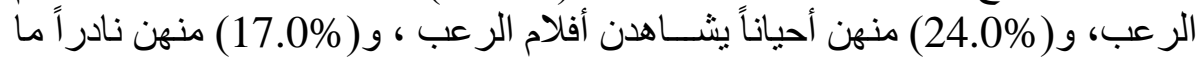

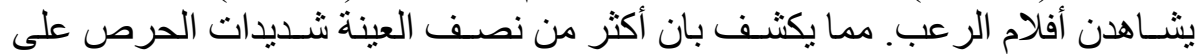
مشاهدة أفلام الر عب باستمر ار مار.

\section{0 ـ كم فلما تشاهدين في الثهر؟}

تم حساب التكرارات و النسب المئوية، كما هو موضح في الجدول التالي: جدول (22): التكرارات والنسب المئوية لمدى مشاهدة العينة افلام الرعب شهرية

\begin{tabular}{|c|c|c|c|}
\hline النسبة المئوية & التكرار & الاستجابة & الرق \\
\hline $49.0 \%$ & 49 & واحد & 1 \\
\hline $18.0 \%$ & 18 & اثثين & 2 \\
\hline $17.0 \%$ & 17 & ثلاث & 3 \\
\hline $13.0 \%$ & 13 & أربعة & 3 \\
\hline $3.0 \%$ & 3 & خمسه فأكثر & 3 \\
\hline $100.0 \%$ & 100 & المجموع & \\
\hline
\end{tabular}




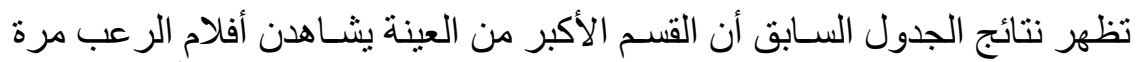

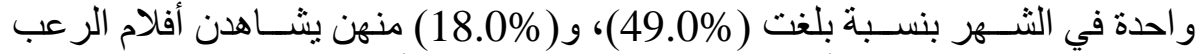

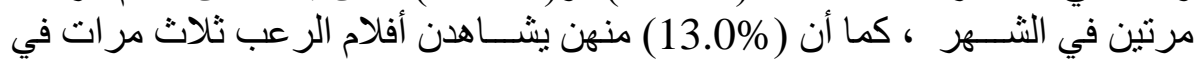

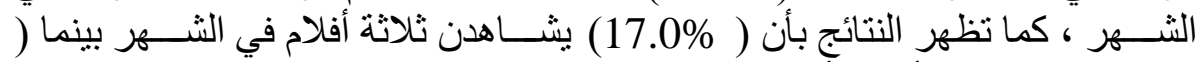

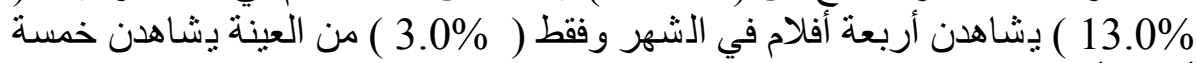

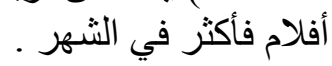

\section{1 ـ ما أفضل الأوقات التي تشاهدين فيها أفلام الرعب؟}

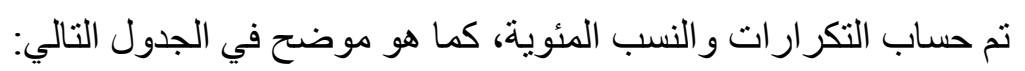

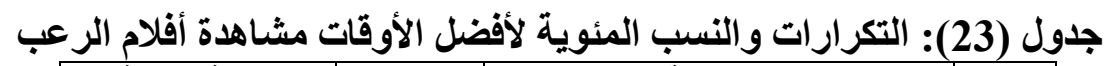

\begin{tabular}{|c|c|c|c|}
\hline النسبة المئوية & التكرار & الاستجابة & الرقم \\
\hline $46.0 \%$ & 46 & في الليل & 1 \\
\hline $34.0 \%$ & 34 & في المساء & 2 \\
\hline $4.0 \%$ & 4 & فترة الظهيرة & 3 \\
\hline $16.0 \%$ & 16 & صباحاً & 3 \\
\hline $100.0 \%$ & 100 & المجموع & \\
\hline
\end{tabular}

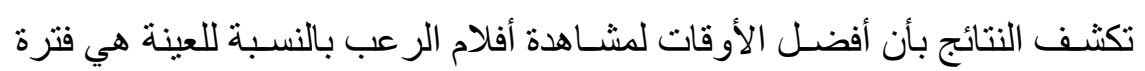

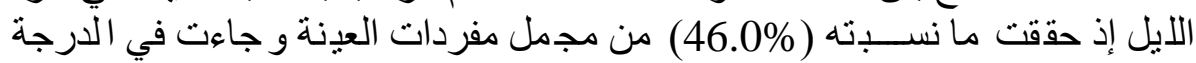

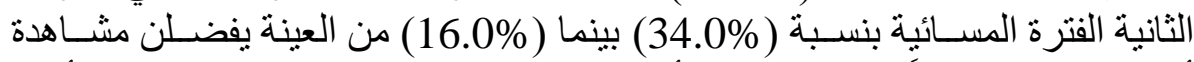

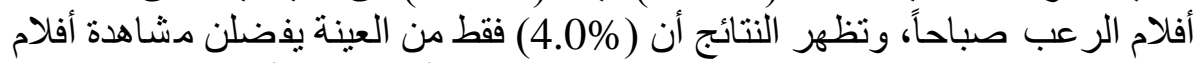

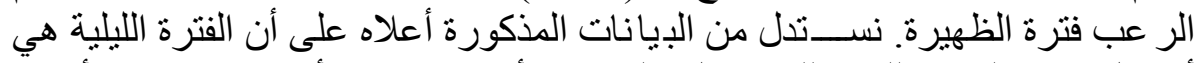

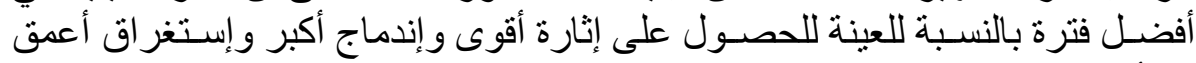
في أجواء الفلم .

$$
22 \text { ـ هل تشاهدين أفلام الرعب ؟ }
$$

تم حساب التكرارات و النسب المئوية، كما هو موضح في الجدول التالي:

جدول (24): التكرارات والنسب المئوية للأشخاص الذين تفضل العينة مشاهدة

\begin{tabular}{|c|c|c|c|}
\hline النسبة المئوية & التكرار & الاستجابة & الرق \\
\hline $12.0 \%$ & 12 & وحدك & 1 \\
\hline $31.0 \%$ & 31 & مع الصديقات & 2 \\
\hline $43.0 \%$ & 43 & الأهل & 3 \\
\hline $14.0 \%$ & 14 & زملاء العمل & 3 \\
\hline $100.0 \%$ & 100 & المجموع & \\
\hline
\end{tabular}

يتبين من الجدول السابق أن ما نسبته (43.0\%) من عينة الدر اسة يفضلن مشاهدة

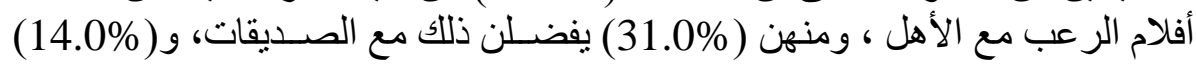


منهن يفضــلن مشــاهدة أفلام الرعب مع زملاء العمل بينما (12.0\%) فقط من عينة

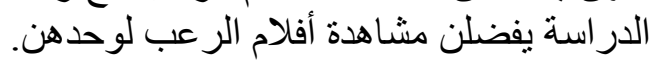

23 ـ هل تناقشين ما تثاهدينه مع الآخرين؟

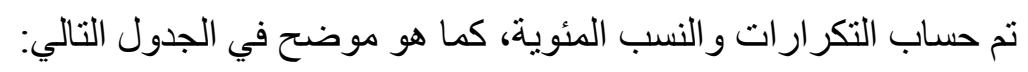

جدول (25): التكرارات والنسب المئوية لمدى مناقشة ما تشاهده العينة في أفلام

\begin{tabular}{|c|c|c|c|}
\hline \multicolumn{4}{|c|}{ الرعب مع الآخرين } \\
\hline النسبة المئوية & 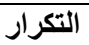 & الاستجابة & الرق - ل الر \\
\hline $7.0 \%$ & 7 & & 1 \\
\hline $48.0 \%$ & 48 & باناً & 2 \\
\hline $12.0 \%$ & 12 & & 3 \\
\hline $33.0 \%$ & 33 & & 3 \\
\hline $100.0 \%$ & 100 & المجموع & \\
\hline
\end{tabular}

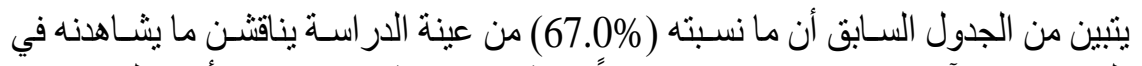

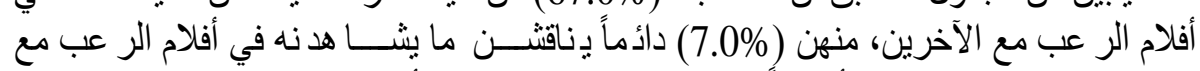

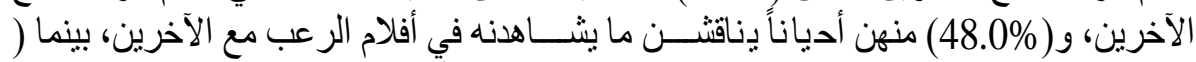

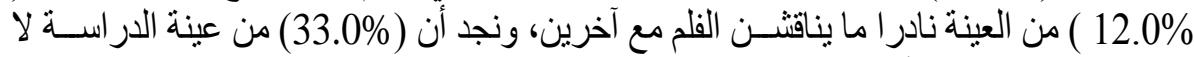
يناقتن ما يشاهدنه في أفلام الرعب مع الآخرين.

24 ـ ما انواع افلام الرعب التي تحرصين على مشاهدتها؟ (يمكن اختيار أكثر

\section{من بديل):}

تم حساب التكرارات و النسب المئوية، كما هو موضح في الجدول التالي:

جدول (26): التكرارات والنسب المئوية لأنواع افلام الرعب التي تحرص العينة

على مشاهدتها

\begin{tabular}{|c|c|c|c|}
\hline النسبة المئوية & التكرار & الاستجابة & الرق \\
\hline $91.0 \%$ & 91 & أفلام الظو اهر و السحر & 4 \\
\hline $86.0 \%$ & 86 & أفلام الغرائب & 5 \\
\hline $41.0 \%$ & 41 & أفلام الوحوش & 6 \\
\hline $27.0 \%$ & 27 & أفلام التقصص & 1 \\
\hline $21.0 \%$ & 21 & أفلام المصابين بالانفصام & 12 \\
\hline $7.0 \%$ & 7 & أفلام القتلة المرضىى & 9 \\
\hline $13.0 \%$ & 13 & أفلام المستنئبين و المتحولين & 13 \\
\hline $20.0 \%$ & 20 & أفلام القتل المنسلسل & 7 \\
\hline $10.0 \%$ & 10 & أفلام مصاصي الدماء & 10 \\
\hline $3.0 \%$ & 3 & أفلام آكلة اللحوم البشرية & 11 \\
\hline $11.0 \%$ & 11 & أفلام الأرواح & 2 \\
\hline $19.0 \%$ & 19 & أفلام الجن & 3 \\
\hline $5.0 \%$ & 5 & أفلام الاعتداء الجنسي & 8 \\
\hline
\end{tabular}


يتبين من الجدول السابق أن أكثر أفلام الرعب التي تحرص العينة على مشاهدتها

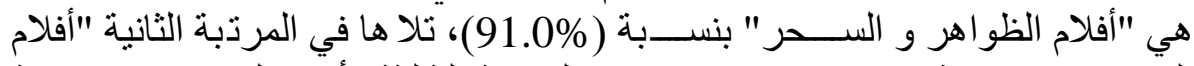

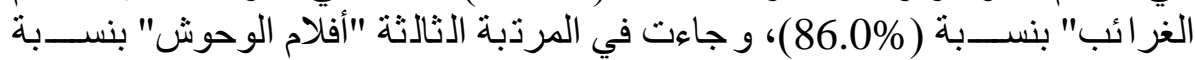

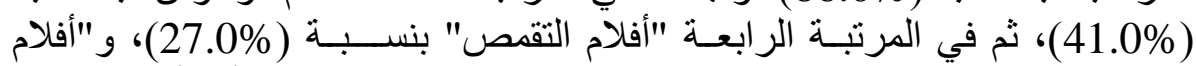

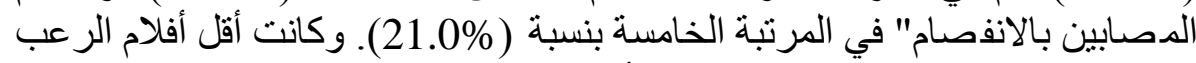

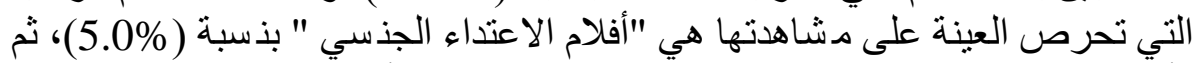

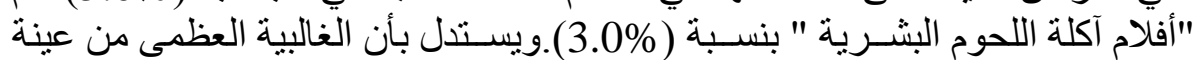

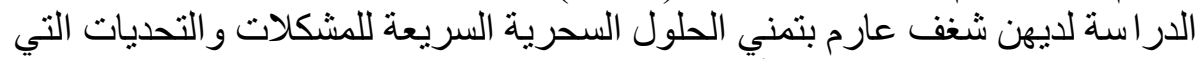
تو اجهرن ولثيو عه في جميع الأوساط و الثقافات الثنات المختلفة .

25 ـ هل تحبين مشاهدة الصفات التالية في الثخصيات القلمية؟ (يمكن اختيار أكثر من بديل): تم حساب التكرارات و النسب المئوية، كما هو موضح في الجدول التالي: جدول (27): التكرارات والنسب المئوية للصفات التي تفضل العينة مشاهدتها في الشخصيات الفلمية المنوية لاتفية

\begin{tabular}{|c|c|c|c|}
\hline النسبة المئوية & التكرار & الاستجابة & 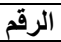 \\
\hline $79.0 \%$ & 79 & القوة المفرطة & 1 \\
\hline $47.0 \%$ & 47 & الضعف المفرط & 2 \\
\hline $69.0 \%$ & 69 & الاعتدال & 3 \\
\hline $37.0 \%$ & 37 & القسوة & 4 \\
\hline $29.0 \%$ & 29 & الخشونة & 5 \\
\hline $83.0 \%$ & 83 & التحدي & 6 \\
\hline $21.0 \%$ & 21 & أخرى (التودد، الانتقام) & 7 \\
\hline
\end{tabular}

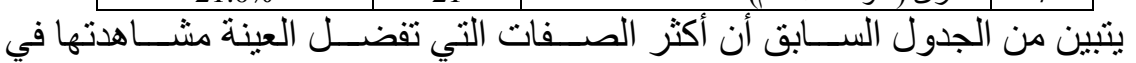

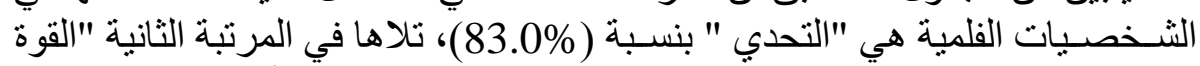

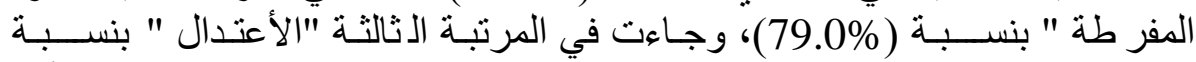

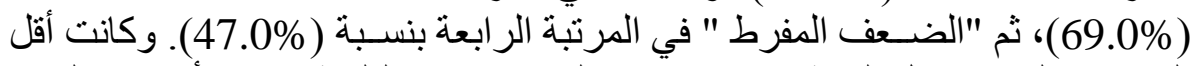

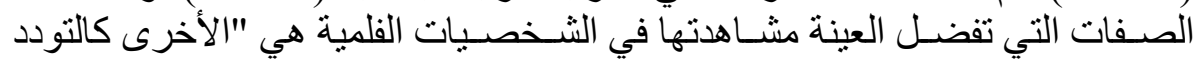

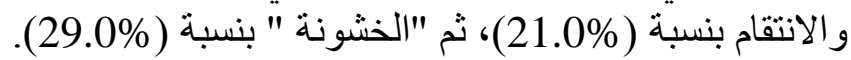

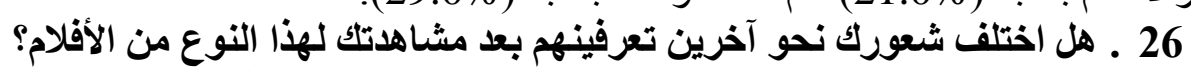

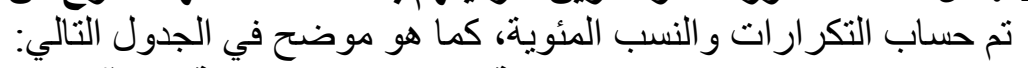

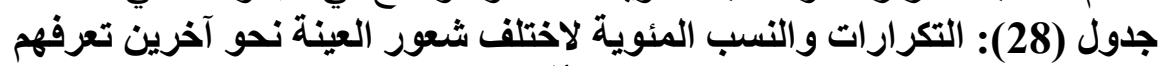

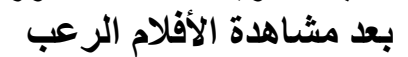

\begin{tabular}{|c|c|c|c|}
\hline النسبة المئوية & التكرار & الاستجابة & الرقم \\
\hline $15.0 \%$ & 15 & اختلف كثير أ & 1 \\
\hline $28.0 \%$ & 28 & اختلف إلى حد ما & 2 \\
\hline $57.0 \%$ & 57 & لا لم يختلف & 3 \\
\hline $100.0 \%$ & 100 & المجموع & \\
\hline
\end{tabular}




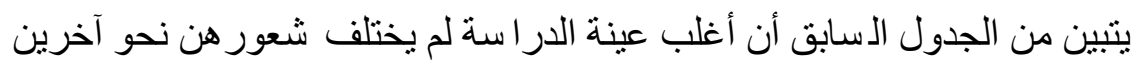

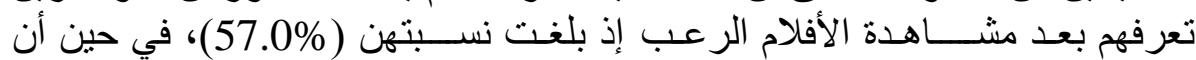

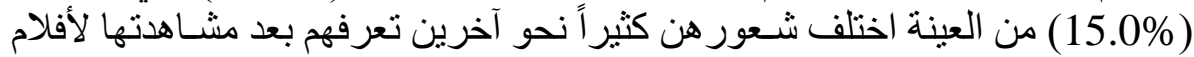

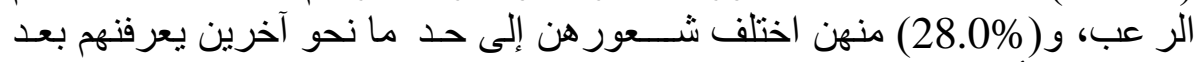

$$
\text { مشاهدتهن لأفلام الرعب. }
$$

27 ـ هل تفكرين بممارسة ما تثاهدينه في هذا النوع من الأفلام مع آخرين؟

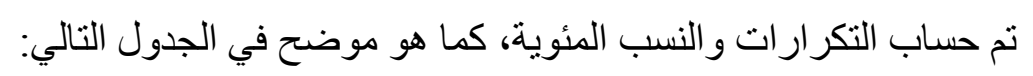

جدول (29): التكرارات والنسب المئوية لمدى تفكير العينة بممارسة ما تشاهده في

\begin{tabular}{|c|c|c|c|}
\hline النسبة المئوية & التكرار & الاستجابة & الرق \\
\hline $21.0 \%$ & 21 & دائماً & 1 \\
\hline $10.0 \%$ & 10 & أحياناً & 2 \\
\hline $17.0 \%$ & 17 & نادراً & 3 \\
\hline $52.0 \%$ & 52 & $\gamma$ & 3 \\
\hline $100.0 \%$ & 100 & المجموع & \\
\hline
\end{tabular}

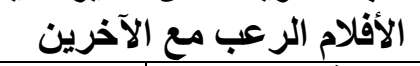

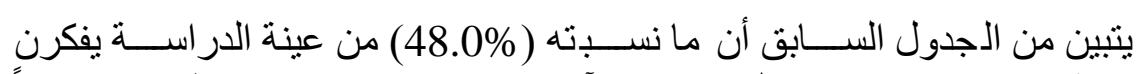

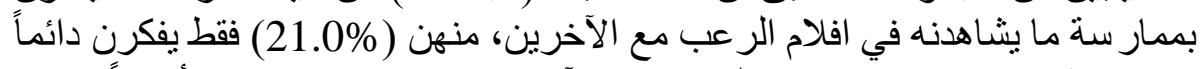

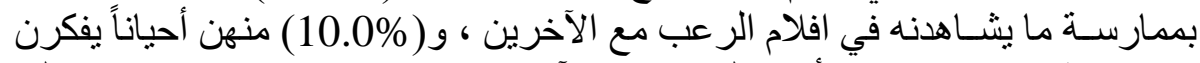

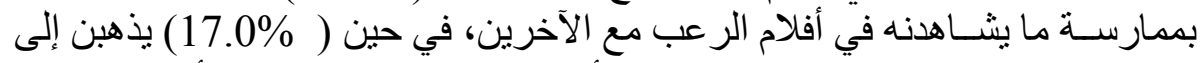

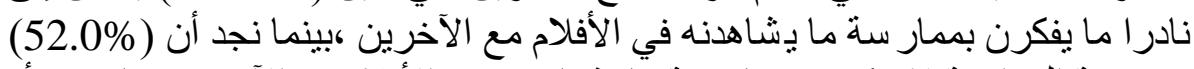

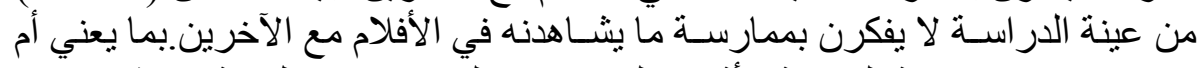

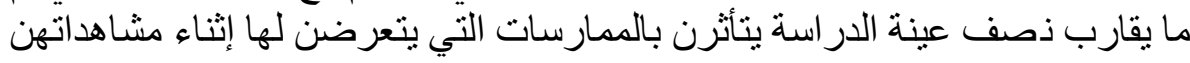
لهذا النوع.

28 هل يبقى في ذاكرتك بعض ما تشاهدينه من مشاهد الفلم لفترة من الزمن؟

$$
\text { تم حساب التكر ارات و النسب المئوية، كما هو موضح في الجدول التالي: }
$$

\begin{tabular}{|c|c|c|c|}
\hline النسبة المئوية & التكرار & الاستجابة & الرق - ل الرق \\
\hline $24.0 \%$ & 24 & ييقى لفترة طويلة & 1 \\
\hline $59.0 \%$ & 59 & يبقى لفترة قصيرة & 2 \\
\hline $17.0 \%$ & 17 & لا ييقى & 3 \\
\hline $100.0 \%$ & 100 & المجموع & \\
\hline
\end{tabular}

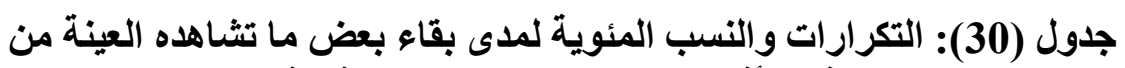

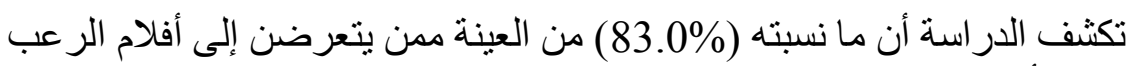

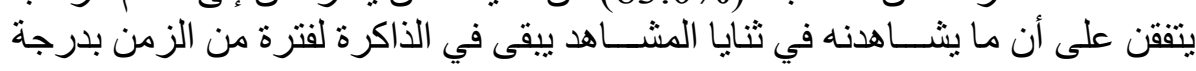




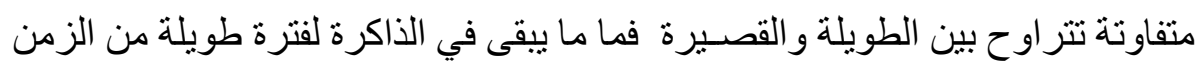

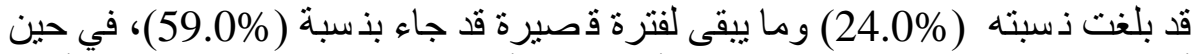

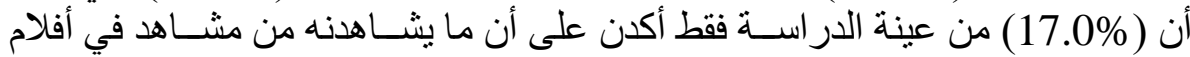
الر عب لا يبقى لفترة طويلة من الزمن في الذاكرة وهي أقل نسبة كثنفتها النتائج.

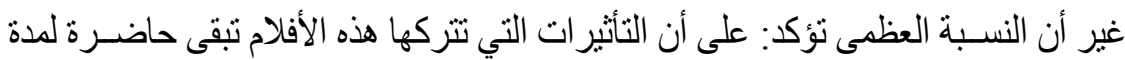

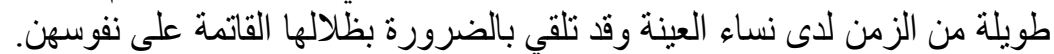

29 ـ تشاهدين أفلام الرعب بناًء على (يمكن اختيار أكثر من بديل):

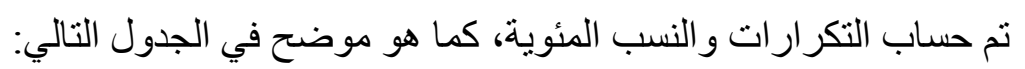

جدول (31): التكرارات والنسب المئوية للعوامل التي تدفع العينة لمشاهدة أفلام الرعب ملئ

\begin{tabular}{|c|c|c|c|}
\hline النسبة المئوية & التكرار & الاستجابة & الرق \\
\hline $43.0 \%$ & 43 & الدعاية التي يحظى بها & 1 \\
\hline $46.0 \%$ & 46 & رأي الأصدقاء & 2 \\
\hline $20.0 \%$ & 20 & نجوم الفلم & 3 \\
\hline $89.0 \%$ & 89 & الولع بأفلام الرعب & 4 \\
\hline $82.0 \%$ & 82 & حبلك للإثارة & 5 \\
\hline $18.0 \%$ & 18 & الحبكة القصصية & 6 \\
\hline $16.0 \%$ & 16 & الأسلوب الفني & 7 \\
\hline
\end{tabular}

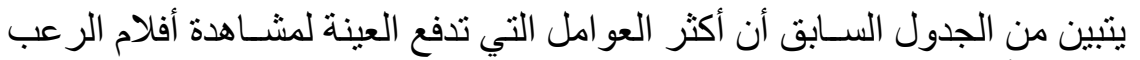

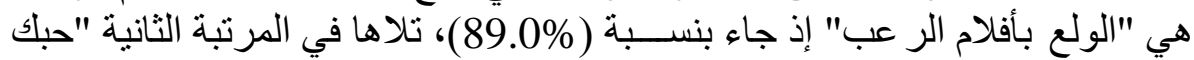

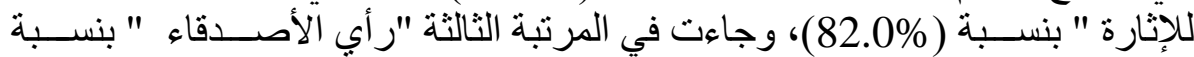

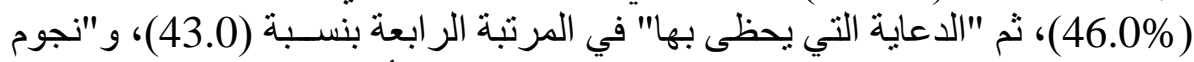

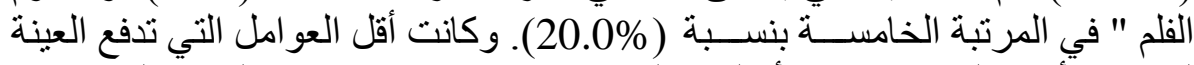

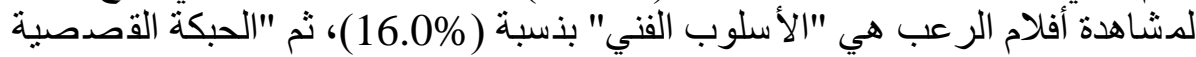

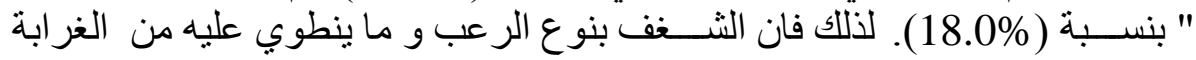

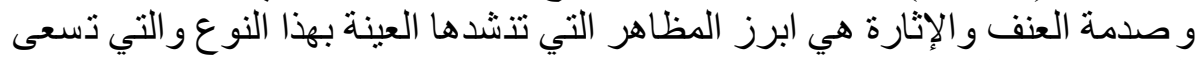

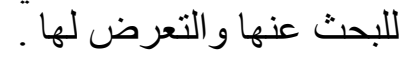

\section{0 ـما درجة تأثرك بهذا النوع من الأفلام؟ لوبه}

تم حساب التكرارات و النسب المئوية، كما هو موضح في الجدول التالي:

جدول (32): التكرارات والنسب المئوية لارجة تأثر العينة بالأفلام الرعب هوبة

\begin{tabular}{|c|c|c|c|}
\hline النسبة المئوية & التكرار & الاستجابة & الرقم \\
\hline $15.0 \%$ & 15 & كبيرة & 1 \\
\hline $42.0 \%$ & 42 & متوسطة & 2 \\
\hline $9.0 \%$ & 9 & ضعيفة & 3 \\
\hline $34.0 \%$ & 34 & لا تأثّير & 4 \\
\hline $100.0 \%$ & 100 & المجموع & \\
\hline
\end{tabular}


يتبين من الجدول السـابق أن ما نسبته ( 66.0\% ) يتأثرن بهذا النوع من الأفلام

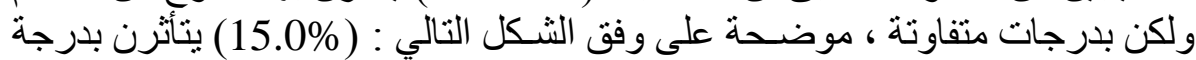

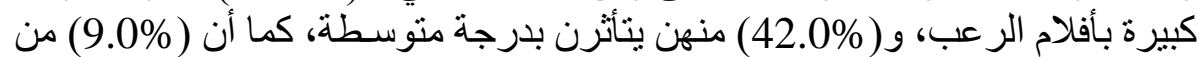

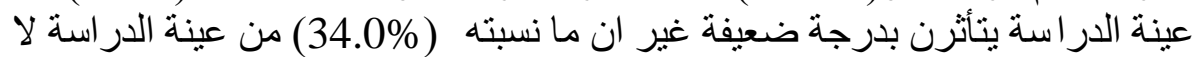

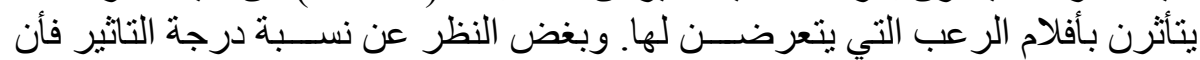

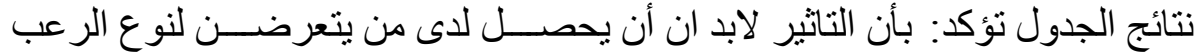

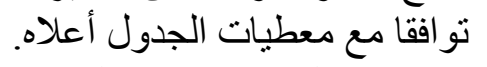

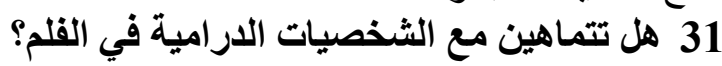

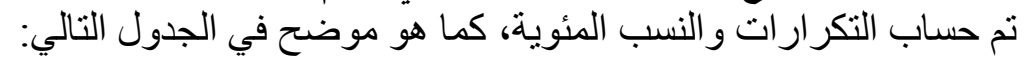
جدول (33): التكرارات والنسب المئوية لمدى تماهي العينة مع الثئية الثخصيات

\begin{tabular}{|c|c|c|c|}
\hline \multicolumn{4}{|c|}{ الدرامية في القلم } \\
\hline النسبة المئوية & ألتكرار & الاستجابة & الرقم - ل الرق \\
\hline $71.0 \%$ & 71 & & 1 \\
\hline $20.0 \%$ & 20 & باناً & 2 \\
\hline $7.0 \%$ & 7 & & 3 \\
\hline $2.0 \%$ & 2 & & 4 \\
\hline $100.0 \%$ & 100 & المجموع & \\
\hline
\end{tabular}

توصلت الدر اسة بأن ( 98.0\% ) الغالبية العظمى من عينة الدر اسة تتماهى بقوة

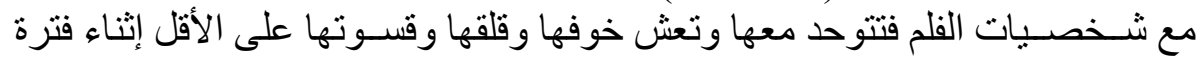
العرض بغض النظر عن آثار المشاهدة لاحقا ـ ويتبين من الجدول السابق أن ما نسبته

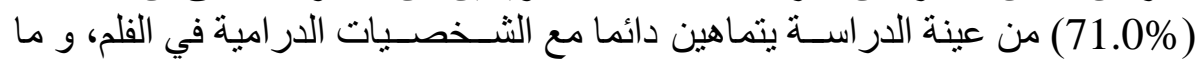
نسـبته (20.0\%) أحيانا يتماهين مع الثـخصيات الدر امية في الفلم، و (7.0\%) منهن التهن

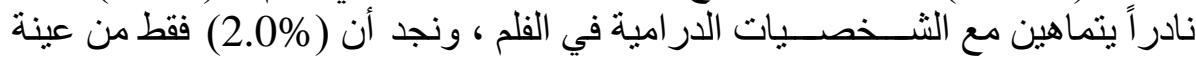

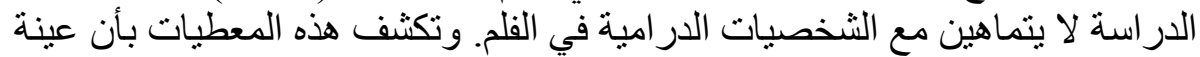

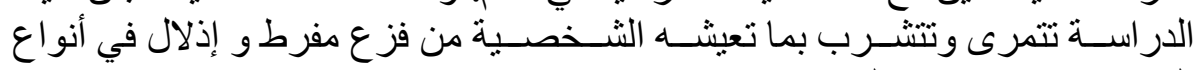

$$
\text { التعذيب ور عب يفوق الحدود . }
$$

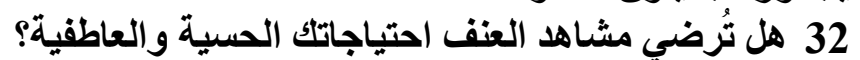

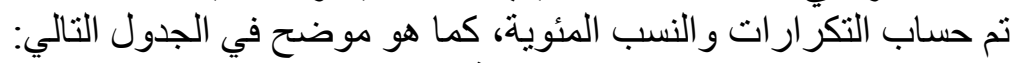

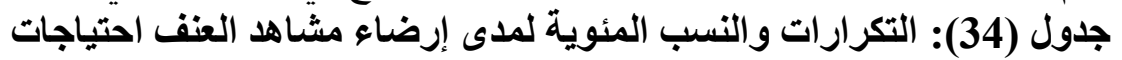

\begin{tabular}{|c|c|c|c|}
\hline النسبة المئوية & التكرار & الاستجابة & الرق \\
\hline $66.0 \%$ & 66 & دائماً & 1 \\
\hline $11.0 \%$ & 11 & أحياناً & 2 \\
\hline $18.0 \%$ & 18 & نادراً & 3 \\
\hline $5.0 \%$ & 5 & $\gamma$ & 3 \\
\hline $100.0 \%$ & 100 & المجموع & \\
\hline
\end{tabular}
العينة الحسية والعاطفية العية ألمية 
يتبين من الجدول السابق أن ما ذسبته (95.0\%) من مجمل عينة الدر اسة يعتقدن

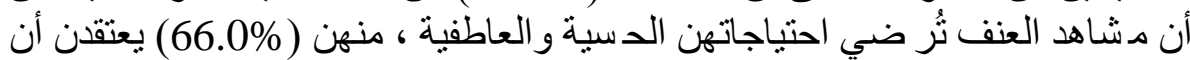

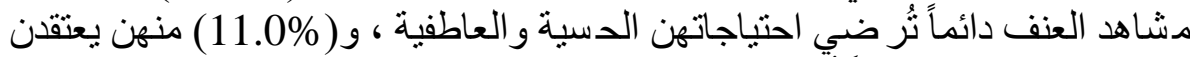

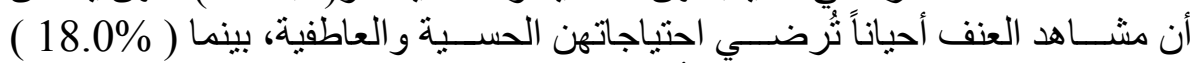

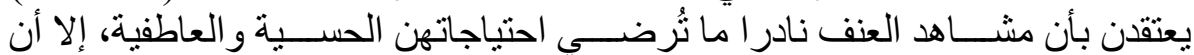

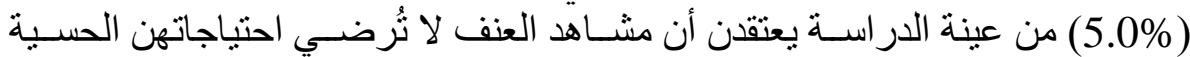

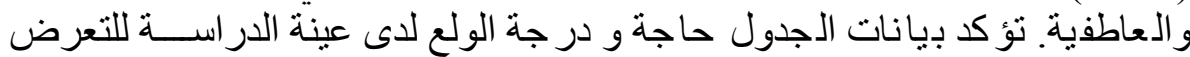

$$
\text { لأفلام الرعب. }
$$

33 ـ ما الأي يجذبك لهذه الأفلام ؟(يمكن اختيار أكثر من بديل):

تم حساب التكرارات و النسب المئوية، كما هو موضح في الجدول التول التالي:

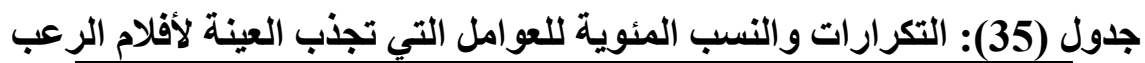

\begin{tabular}{|c|c|c|c|}
\hline النسبة المئوية & التكرار & الاستجابة & 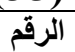 \\
\hline $64.0 \%$ & 64 & الإثارة & 1 \\
\hline $58.0 \%$ & 58 & 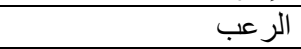 & 3 \\
\hline $44.0 \%$ & 44 & الصدمة & 4 \\
\hline $41.0 \%$ & 41 & الجو السينمائي & 13 \\
\hline $39.0 \%$ & 39 & الإخراج & 16 \\
\hline $37.0 \%$ & 37 & النجوم & 17 \\
\hline $36.0 \%$ & 36 & الحبكة & 5 \\
\hline $31.0 \%$ & 31 & قوة الثرير & 11 \\
\hline $30.0 \%$ & 30 & الإضـاءة و الألو ان & 15 \\
\hline $28.0 \%$ & 28 & العنف & 6 \\
\hline $25.0 \%$ & 25 & المؤثر ات البصرية & 14 \\
\hline $23.0 \%$ & 23 & المعالجات الدرامية للقصة & 12 \\
\hline $21.0 \%$ & 21 & الذوف & 2 \\
\hline $20.0 \%$ & 20 & الوحشية & 7 \\
\hline $17.0 \%$ & 17 & الأمكنة المنعزلة و الديكور & 8 \\
\hline $9.0 \%$ & 9 & السادية & 9 \\
\hline $6.0 \%$ & 6 & ضعف المرأة & 10 \\
\hline
\end{tabular}

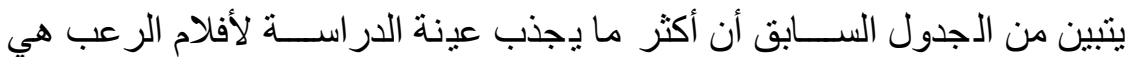

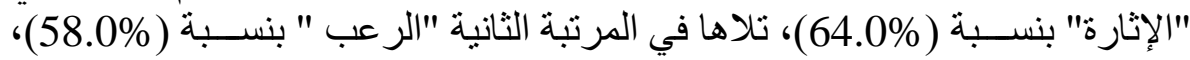

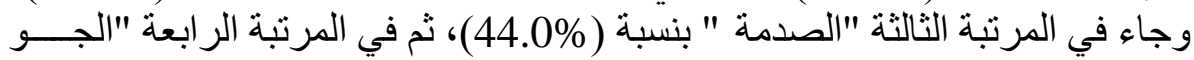

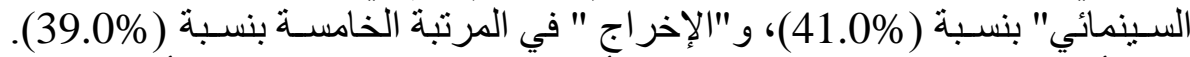

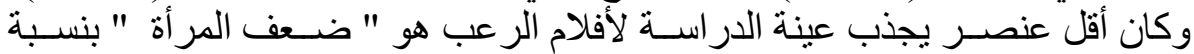

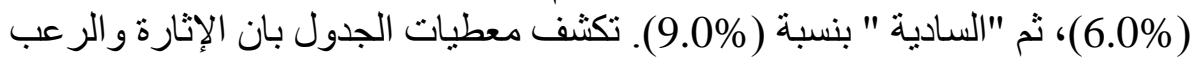


وصـدمة الخوف و الفزع تحتل الأفضـلية في قائمة عناصـر جذب عينة الدر اســة لنوع

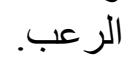

\section{4 ـ الأسباب التي تدفعك لمشاهدة أفلام الرعب:}

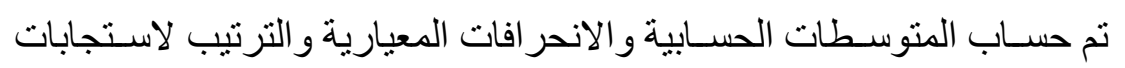
العينة، كما هو موضح في الجدول النالي:

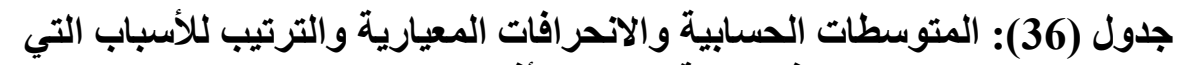
تلففع العينة لمشاهدة والفلام الرعب المباربة

\begin{tabular}{|c|c|c|c|c|c|}
\hline الترتيب & الانحريارية & الأهمية & المستوسطابية & 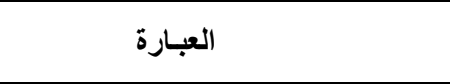 & 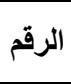 \\
\hline 1 & 1.127 & $81.2 \%$ & 4.060 & أرى فيها ما لا أر اه في الحياة الو اقعية & 14 \\
\hline 2 & 1.114 & $80.6 \%$ & 4.030 & لأني احب الإثارة التي فيها & 9 \\
\hline 3 & 1.133 & $79.8 \%$ & 3.990 & تجعلني اشعر بأني مستثارة & 8 \\
\hline 4 & 1.134 & $78.4 \%$ & 3.920 & تجعلني أرتقي على المو اقف الصعبة & 22 \\
\hline 5 & 1.116 & $78.4 \%$ & 3.920 & لا هتمامي بهذا النوع من الأفلام & 5 \\
\hline 6 & 1.134 & $78.4 \%$ & 3.920 & لأني أجد فيها أشياءً محرومة منها & 25 \\
\hline 7 & 1.238 & $77.8 \%$ & 3.890 & اتعرف على مكنونات النفس الإنسانية & 2 \\
\hline 8 & 1.178 & $77.4 \%$ & 3.870 & أجد فيها شيئا من التنفيس عن نفسي & 11 \\
\hline 9 & 1.218 & $77.0 \%$ & 3.850 & لأن حياتي مضطربة وصاخبة & 7 \\
\hline 10 & 1.077 & $76.4 \%$ & 3.820 & أتعرف على الجديد فيها & 4 \\
\hline 11 & 1.234 & $76.4 \%$ & 3.820 & لأنها تريحني وتساعدني على الأسترخاء & 13 \\
\hline 12 & 1.125 & $76.2 \%$ & 3.810 & لأني أفرغ فيها توتري & 12 \\
\hline 13 & 1.328 & $75.8 \%$ & 3.790 & للحصول على خبر ات جديدة & 1 \\
\hline 14 & 1.104 & $75.8 \%$ & 3.790 & أحب مشاهدتها حين أكون منز عجة & 20 \\
\hline 15 & 1.329 & $75.0 \%$ & 3.750 & تمتعني وتسليني & 17 \\
\hline 16 & 1.390 & $74.8 \%$ & 3.740 & لاكتساب خبر ات من تجارب الآخرين & 6 \\
\hline 17 & 1.352 & $74.0 \%$ & 3.700 & تشعرني بأني قوية & 15 \\
\hline 18 & 1.195 & $73.8 \%$ & 3.690 & تخلصني من الملل و الرتابة & 10 \\
\hline 19 & 1.294 & $73.6 \%$ & 3.680 & تحقق لي طموحات مكبوتة & 21 \\
\hline 20 & 1.196 & $72.4 \%$ & 3.620 & لأنها تشبع فضولي & 3 \\
\hline 21 & 1.311 & $71.8 \%$ & 3.590 & تجعلني متيقظة لأفعال الغير & 16 \\
\hline 22 & 1.313 & $71.0 \%$ & 3.550 & توفر لي متعة حسية و عاطفية & 19 \\
\hline 23 & 1.359 & $69.0 \%$ & 3.450 & أثنبت لنفسي بأني قوية & 23 \\
\hline 24 & 1.313 & $68.8 \%$ & 3.440 & تجعلني أو اجه العنف بالعنف & 24 \\
\hline 25 & 1.273 & $68.6 \%$ & 3.430 & تجعلني اتخلص من غضبي & 18 \\
\hline
\end{tabular}

تظهر نتائج الجدول الســابق أن أكثر الأســباب التي تدفع العينة لمشـــــاهدة أفلام

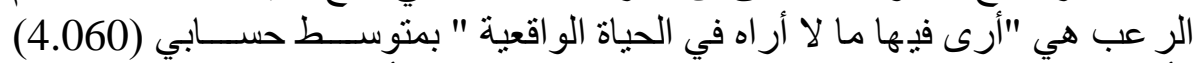

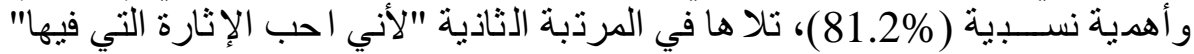
بمتو سط حسابي (4.030) و أهمية نسبية (81.2\%) (80.6\%)، و "تجعلني اشعر بأني مستثارة " 


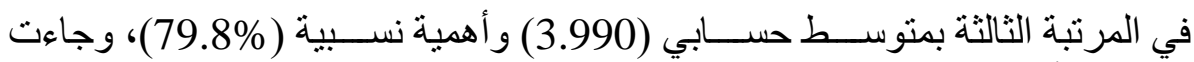

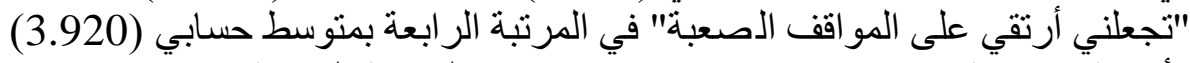

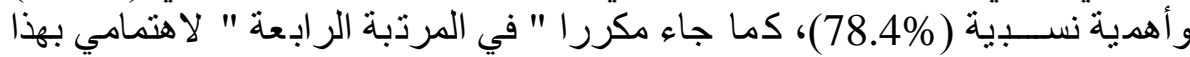
النوع من الأفلام " بمتوسط حسابي (78.920) و أهمية نسبية (78.4\%).

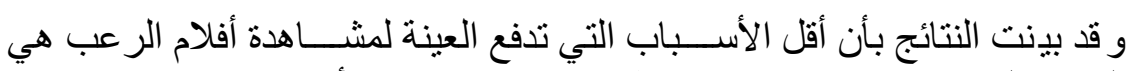
"تجعلني اتخلص من غضبي " بمنو سط حسابي (3.430) و أهمية ذسبية (3.40\% (38.6\%)،

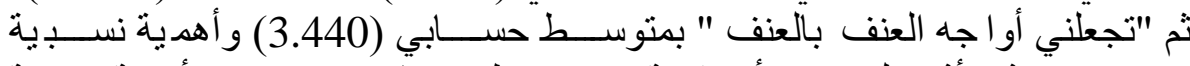

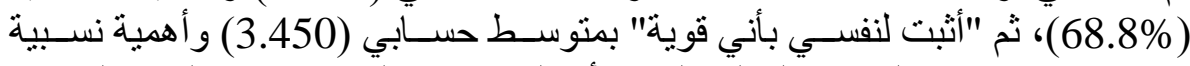

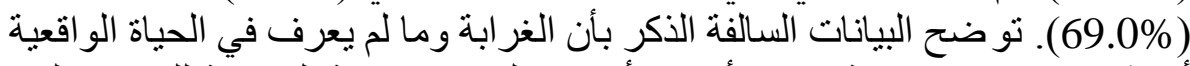

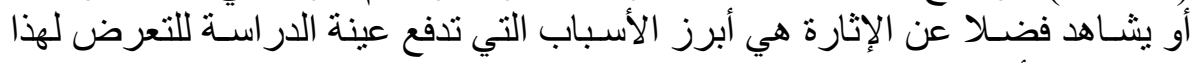
النوع من الأفلام.

35 ـ بماذا تشعرين بعد الانتهاء من مشاهدتك للقلم ؟(يمكن اختيار أكثر من بديل):

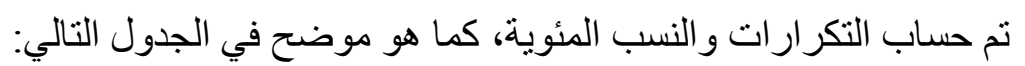
جلول (37): التكرارات والنسب المئوية لشعور العينة بعد الانتهاء من مشاهدة فلم الرعب فئه

\begin{tabular}{|c|c|c|c|}
\hline النسبة المئوية & التكرار & الاستجابة & الرقم \\
\hline $45.0 \%$ & 45 & بأنك أكثر قلقا & 16 \\
\hline $42.0 \%$ & 42 & بالانشداد إلى الداخل & 6 \\
\hline $37.0 \%$ & 37 & بالر غبة العاطفية & 4 \\
\hline $34.0 \%$ & 34 & بالمتعةة & 2 \\
\hline $32.0 \%$ & 32 & بالخوف & 5 \\
\hline $30.0 \%$ & 30 & بالاشمئز از & 9 \\
\hline $30.0 \%$ & 30 & بالانفتاح على الآخرين & 12 \\
\hline $27.0 \%$ & 27 & بالقوة و السيطرة & 10 \\
\hline $27.0 \%$ & 27 & قادرة على تجاوز المشاكل & 14 \\
\hline $24.0 \%$ & 24 & بالانغلاق على الذات & 11 \\
\hline $23.0 \%$ & 23 & بأنكا أكثر أمناً & 15 \\
\hline $21.0 \%$ & 21 & بالر احة & 1 \\
\hline $17.0 \%$ & 17 & بالسعادة والرضى & 7 \\
\hline $13.0 \%$ & 13 & بالامتعاض و الازدر اء & 8 \\
\hline $11.0 \%$ & 11 & بانعدام الثقة في الآخرين & 13 \\
\hline $8.0 \%$ & 8 & أتقصص دور الضحية في الفلم & 17 \\
\hline $6.0 \%$ & 6 & أثتقص دور الثخصية القوية & 3 \\
\hline
\end{tabular}

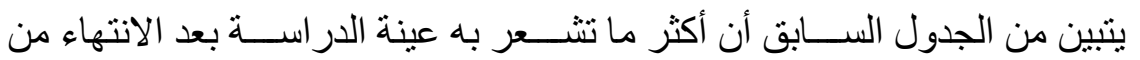

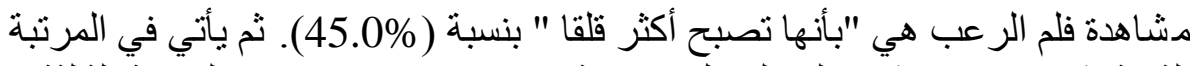

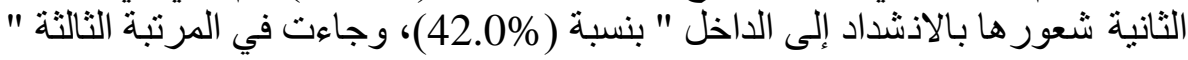

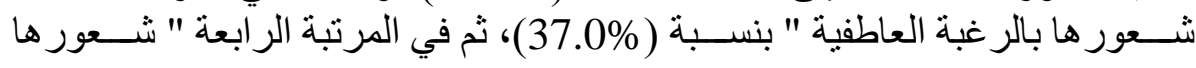




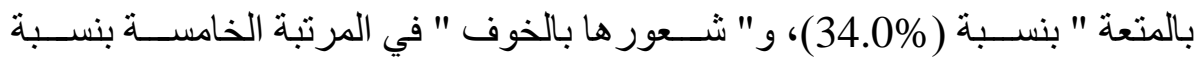

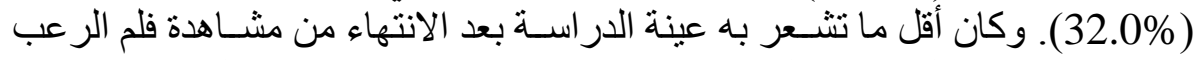

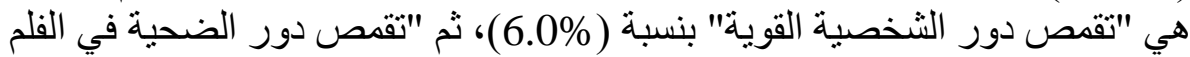

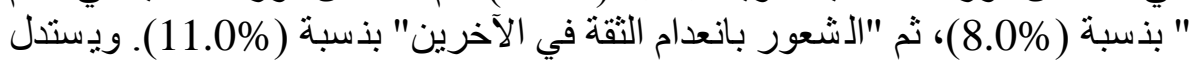

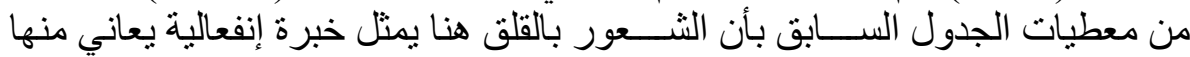

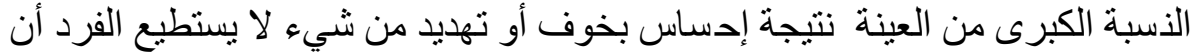

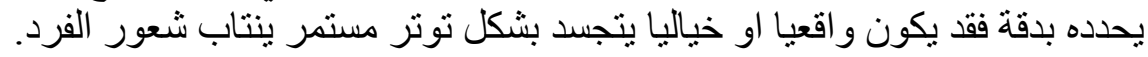
36 ـ دوافع مشاهدة أفلام الرعب:

تم حسـاب المتوسـطات الحسـابية والانحر افات المعيارية و الترتيب لاسـتجابات العينة، كما هو موضتح في الجدول التالي:

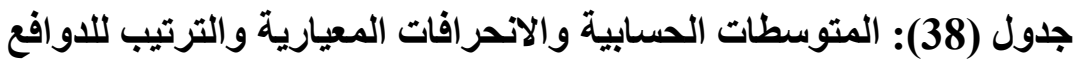
بمشاهدة العينة لأفلام الرعب المبات المباري

\begin{tabular}{|c|c|c|c|c|c|}
\hline الترتيب & المعيراية & النسبية & الحستوسبية & العبـارة & الرقم \\
\hline 1 & 0.692 & $77.0 \%$ & 2.310 & لأنها مشوقة وفيها إثارة كبيرة & 31 \\
\hline 2 & 0.649 & $75.7 \%$ & 2.270 & تعزز قوتي وثقتي بنفسي & 18 \\
\hline 3 & 0.661 & $75.3 \%$ & 2.260 & تعلمني كيفية التصرف في المو اقف الصعبة & 16 \\
\hline 4 & 0.597 & $74.7 \%$ & 2.240 & لأنها ترفه عني وتسليني & 15 \\
\hline 5 & 0.715 & $73.7 \%$ & 2.210 & لأني أحب نجوم الفلم & 30 \\
\hline 6 & 0.677 & $73.3 \%$ & 2.200 & لالانها تدفعني إلى التخيل & 3 \\
\hline 7 & 0.662 & $73.0 \%$ & 2.190 & لأني أحب مشاهدة المرأة تتنصر على خوفها & 34 \\
\hline 8 & 0.642 & $72.7 \%$ & 2.180 & تجعلني أشعر بأني أكبر من المشكلة & 6 \\
\hline 9 & 0.744 & $72.7 \%$ & 2.180 & تخلصني من غضبي & 8 \\
\hline 10 & 0.716 & $72.7 \%$ & 2.170 & لأنها تنسيني الواقع & 5 \\
\hline 11 & 0.697 & $72.3 \%$ & 2.170 & لآني أتعلم منها أنشياءً لم أعرفها من قبل & 28 \\
\hline 12 & 0.692 & $72.0 \%$ & 2.160 & تجعلني أفكر بشكل بناء ومفيد & 7 \\
\hline 13 & 0.702 & $71.7 \%$ & 2.150 & عندما أكون محبطة & 1 \\
\hline 14 & 0.730 & $71.7 \%$ & 2.150 & لالني تعرضت لتجارب مماثلة & 22 \\
\hline 15 & 0.657 & $71.7 \%$ & 2.150 & لأنها تثير في انفعالات قوية & 25 \\
\hline 16 & 0.720 & $71.0 \%$ & 2.130 & لأنها تشعرني بتحرر أحاسيسي المكبوتة & 17 \\
\hline 17 & 0.677 & $71.0 \%$ & 2.130 & تساعدني على التخلص من الملل و الرتابة & 29 \\
\hline 18 & 0.729 & $70.7 \%$ & 2.120 & لأنها تذكرني بحو ادث ماضية & 9 \\
\hline 19 & 0.715 & $70.7 \%$ & 2.120 & تجعلني لا أكترث لأحد & 12 \\
\hline 20 & 0.715 & $70.7 \%$ & 2.120 & تعزز لدي بعض الممارسات السلوكية & 19 \\
\hline 21 & 0.715 & $70.7 \%$ & 2.120 & تعرفني بكيفية تثوير الخوف لاى الآخر & 33 \\
\hline 22 & 0.644 & $70.0 \%$ & 2.100 & لأنها تولد لاي أحلام اليقظة & 4 \\
\hline 23 & 0.704 & $70.0 \%$ & 2.100 & تعلمني كيفية لفت الانتباه و إثبات الذات & 26 \\
\hline 24 & 0.712 & $69.7 \%$ & 2.090 & تخلصني من النز عات العدو انية & 20 \\
\hline 25 & 0.726 & $69.7 \%$ & 2.090 & فيها فرص لانتصار المر أة الضحية & 24 \\
\hline
\end{tabular}


دوافع تعرض المر أة لأفلام الرعب والإشباعات المتحققة منها

\begin{tabular}{|c|c|c|c|c|c|}
\hline 26 & 0.677 & $69.3 \%$ & 2.080 & تزيدني خبرة بأعماق النفس البشرية & 14 \\
\hline 27 & 0.748 & $69.3 \%$ & 2.080 & عندما اشعر بفر اغ كبير من حولي & 2 \\
\hline 28 & 0.640 & $69.0 \%$ & 2.070 & تعزز لدي الدعم النفسي & 13 \\
\hline 29 & 0.736 & $68.7 \%$ & 2.060 & توجه غضبي إلى مكان آخر & 10 \\
\hline 30 & 0.730 & $68.3 \%$ & 2.050 & تعزز عندي تقدير الذات & 21 \\
\hline 31 & 0.730 & $68.3 \%$ & 2.050 & أحب أن اشارك الثخوص تجاربهر & 32 \\
\hline 32 & 0.704 & $67.7 \%$ & 2.030 & لأني أحب أن أتخيل نفسي مكان الضحية & 27 \\
\hline 33 & 0.718 & $67.0 \%$ & 2.010 & لأني أجد في عرضها للرعب استمتاعا & 23 \\
\hline 34 & 0.750 & $64.7 \%$ & 1.940 & فيها مثاهد حساسة & 24 \\
\hline
\end{tabular}

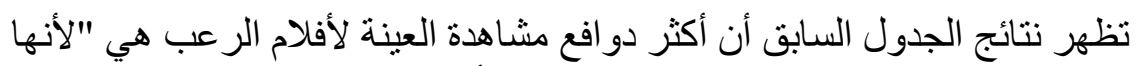

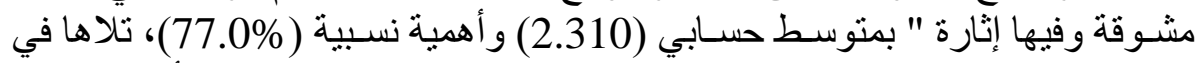

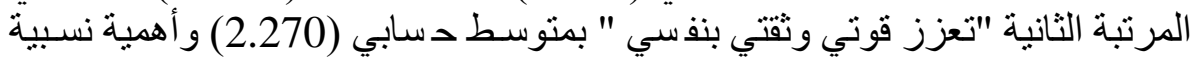

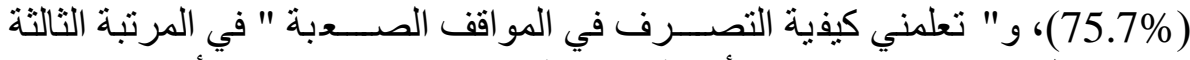

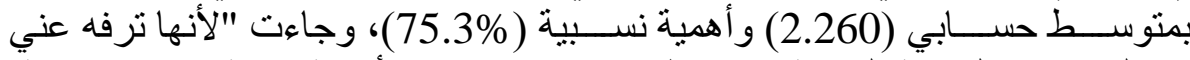

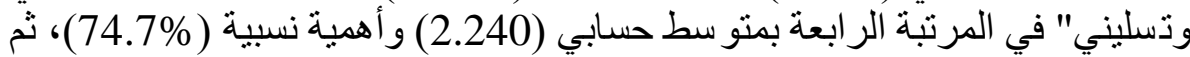
"لأني أحب نجوم الفلم" في المرتبة الخامسة بمتو سط حسابي (2.210) و أهمية نسبية

وتظهر نتائج الجدول السابق أن أقل دوافع مشاهدة العينة لأفلام الرعب هي "فيها

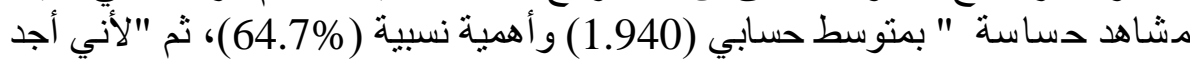

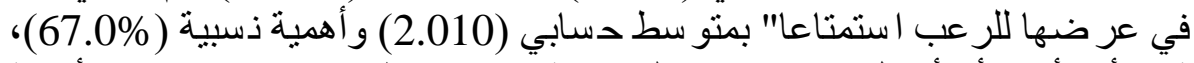

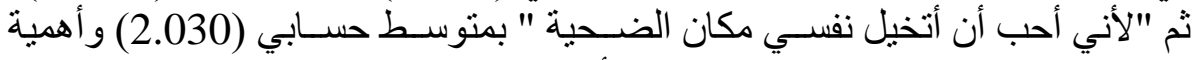

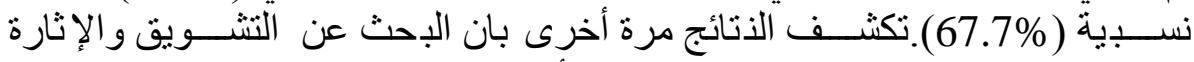

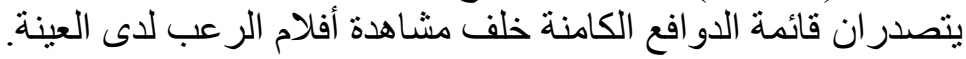

37 هل ترين أن تعرضك لأفلام الرعب يشبع حاجاتك الآتية (يمكن اختيار أكثر

من بديل): مل ترين ان

تم حساب التكرارات و النسب المئوية، كما هو موضح في الجدول التالي:

جدول (39): التكرارات والنسب المئوية لمدى اشباع أفلام الرعب لحاجات العينة

\begin{tabular}{|c|c|c|c|}
\hline النسبة المئوية & 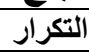 & الاستجابة & الرقم \\
\hline $58.0 \%$ & 58 & النفسية & 1 \\
\hline $43.0 \%$ & 43 & الحسية & 2 \\
\hline $40.0 \%$ & 40 & العاطفية - ل العية & 3 \\
\hline $34.0 \%$ & 34 & الفكرية & 4 \\
\hline $22.0 \%$ & 22 & المعرفية & 5 \\
\hline $28.0 \%$ & 28 & السلوكية & 6 \\
\hline $7.0 \%$ & 7 & أخرى (الاجتماعية، الدينية) & 7 \\
\hline
\end{tabular}




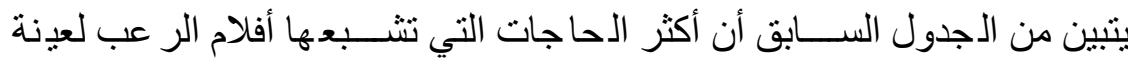

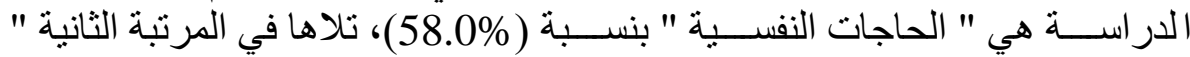

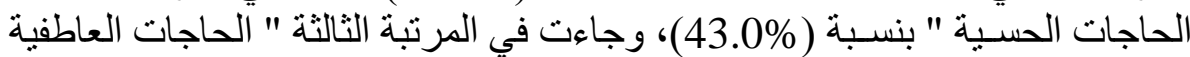

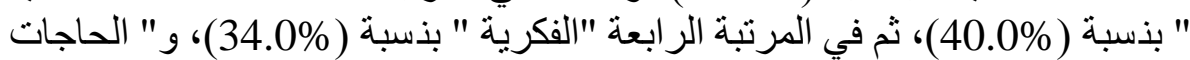

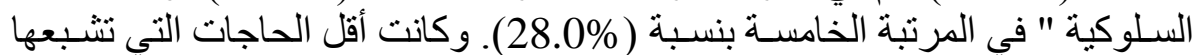

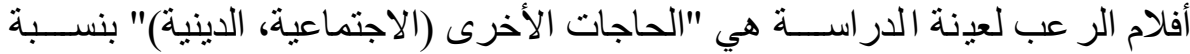

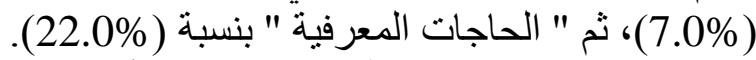

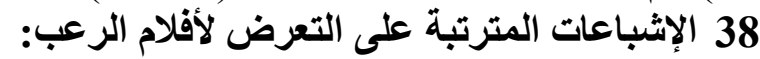

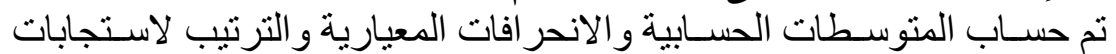

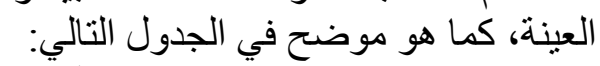
جدول (40): المتوسطات الحسابية والانحر افتات المعيارية والترتيب للإشباعات

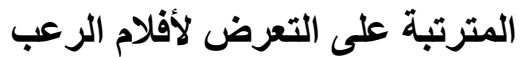

\begin{tabular}{|c|c|c|c|c|c|}
\hline الترتيب & الالمعيارية افتات & الالهميية & المتوسابية & 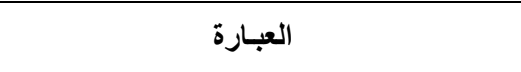 & 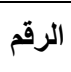 \\
\hline 1 & 1.118 & $82.2 \%$ & 4.110 & أتعرف على طرق جديدة للإِثارة & 6 \\
\hline 2 & 1.098 & $81.6 \%$ & 4.080 & (تملؤني إنفعالا و إثارة ) & 17 \\
\hline 3 & 1.028 & $81.4 \%$ & 4.070 & تساعدني على المرور بتجربة فريدة & 12 \\
\hline 4 & 1.109 & $81.0 \%$ & 4.050 & تشبع حب المعرفة و الاستطلاع لدي & 2 \\
\hline 5 & 1.141 & $80.8 \%$ & 4.040 & تخلصني من الثعور بالوحدة & 3 \\
\hline 6 & 1.049 & $80.6 \%$ & 4.030 & آشعر أني أتماهى مع شخصيات الفلم & 13 \\
\hline 7 & 1.101 & $80.4 \%$ & 4.020 & أكتسب مهار ات في أساليب التخلص من المازق & 21 \\
\hline 8 & 1.078 & $80.2 \%$ & 4.010 & معرفة الأساليب التي تحل بها المر أة مشاكلها & 22 \\
\hline 9 & 1.059 & $79.8 \%$ & 3.990 & آشعر باني قادرة علَّى ابتكار حلو لا للضحية & 16 \\
\hline 10 & 1.029 & $79.4 \%$ & 3.970 & الإلمام بكوَّامن النفس البشرية & 8 \\
\hline 11 & 1.100 & $79.2 \%$ & 3.960 & لآن الأمور فيها تخرج عن السبطرة & 4 \\
\hline 12 & 1.145 & $79.2 \%$ & 3.960 & أشعر بالر احة و التحرر من القيود & 11 \\
\hline 13 & 1.118 & $78.8 \%$ & 3.940 & تشعرني بقوة الارتباط بالضحية & 7 \\
\hline 14 & 1.103 & $78.6 \%$ & 3.930 & تساعدني في فهم نظرة الأخرين نحوي & 26 \\
\hline 15 & 1.107 & $78.4 \%$ & 3.920 & لاني أرى فيها مشـاهد لا قيود عليها & 5 \\
\hline 16 & 1.134 & $78.4 \%$ & 3.920 & تساعدني في إطلاق الاحاسيس المكبوتة & 24 \\
\hline 17 & 1.131 & $77.6 \%$ & 3.880 & تساعد في تنمية قدرتي على التخيل & 15 \\
\hline 18 & 1.134 & $77.4 \%$ & 3.870 & تعرفني كيف اتصرف في المو اقف الصعبة & 10 \\
\hline 19 & 1.429 & $77.2 \%$ & 3.860 & تخلصني من الضجر و الرّتنابة & 1 \\
\hline 20 & 1.015 & $77.2 \%$ & 3.860 & أشعر بانَي أستعيد نشاطي وحيويتي & 19 \\
\hline 21 & 1.123 & $77.0 \%$ & 3.850 & تشعرني بّالارتباط بنجمي المفضل & 27 \\
\hline 22 & 1.116 & $76.2 \%$ & 3.810 & أشعر بآني الضحية & 25 \\
\hline 23 & 1.140 & $75.8 \%$ & 3.790 & توسع مدارَّكي حول التصرفات الغريزية & 9 \\
\hline 24 & 1.076 & $75.8 \%$ & 3.790 & أشعر أني أعيش تجربة الشخوص & 20 \\
\hline 25 & 1.079 & $75.6 \%$ & 3.780 & تزداد مخاّوفي من الآخرين & 23 \\
\hline 26 & 1.081 & $75.4 \%$ & 3.770 & أشعر بقدتي على مو اجهة الاخطار & 18 \\
\hline 27 & 1.035 & $73.4 \%$ & 3.670 & تساعدني على فهم الأخرين & 14 \\
\hline
\end{tabular}

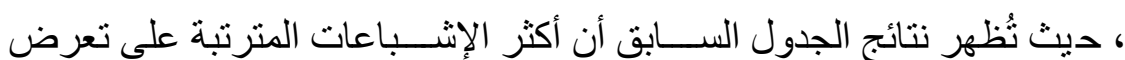

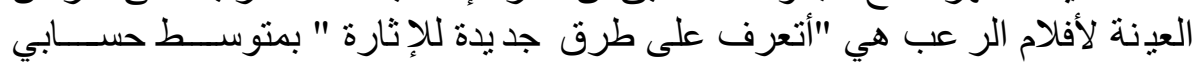




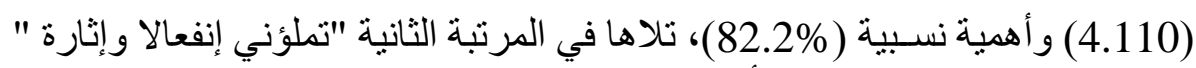

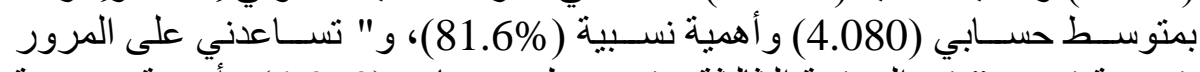

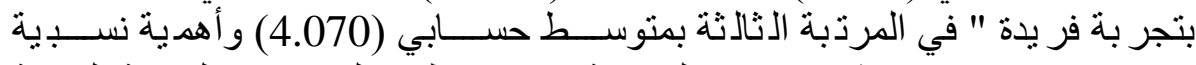

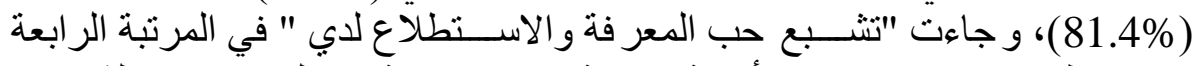

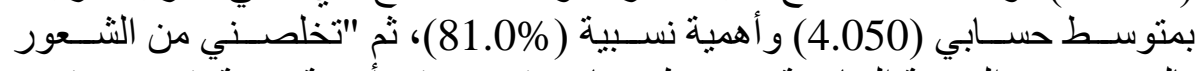
بالوحدة " في المرتبة الخامسة بمتوسط حسابي (4.040) و وأهمية نسبية (810) (80.8\%).

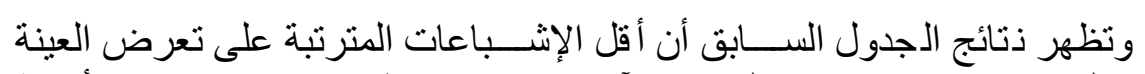

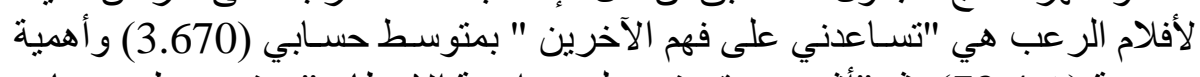

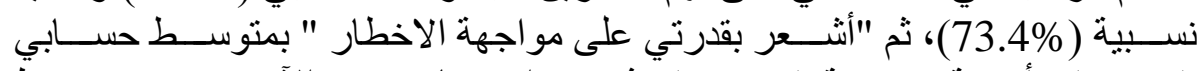

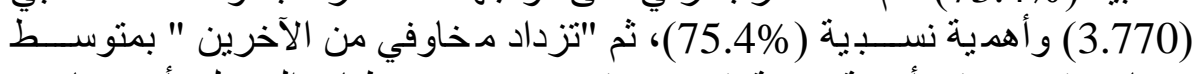

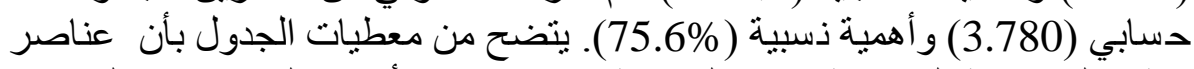

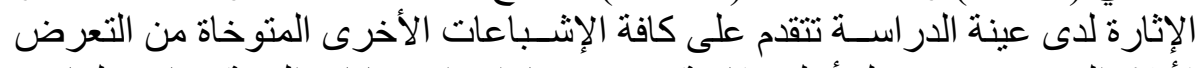

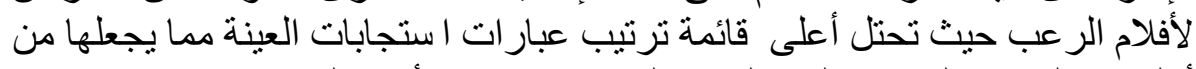

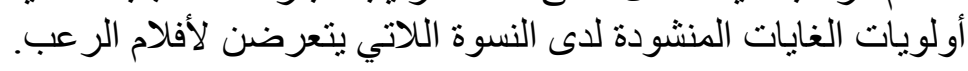

$$
\text { المحور الثالث: الإجابة على فروض الدراسة }
$$

الفرض الأول: لا توجد علاقة ارتباطية دالة إحصسائياً بين دوافع تعرض الإبه المرأة لأفلام الرعب والإثباعات المتحققة منها.

تم التحقق من صحة الفرض من خلال معامل ارتباط بير سون، كما هو موضح

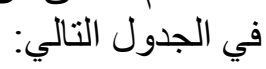

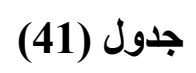

دلالة العلاقة الارتباطية بين دوافع تعرض المرأة لأفلام الرعب والإشباعات

\begin{tabular}{|c|c|c|}
\hline مستوى الدلالة & ن & قيمة معامل الارتباط \\
\hline 0.01 & 100 & $0.41(* *)$ \\
\hline
\end{tabular}
المتحققة منها

$$
\text { * * الارتباط دال إحصائيا عند (a =0.05). }
$$

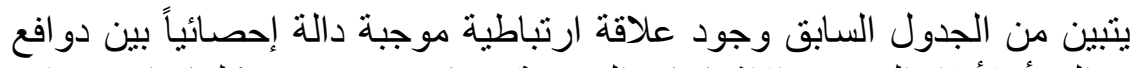

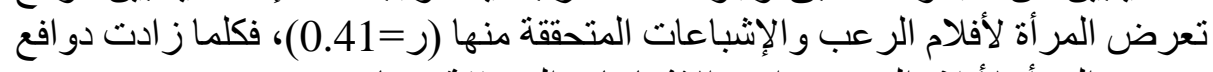
تعرض المر أة لأفلام الرمب الرعب زادت الإنباعات الاعات المتحققة منها. 
الفرض الثاني: لا توجد علاقة ارتباطية دالة إحصــائياً بين دوافع تعرض المر أة لأفلام الرعب و الآثار الناجمة عنها.

تم التحقق من صحة الفرض من خلال معامل ارتباط بير سون، كما هو موضح

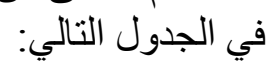

\section{جدول (42)}

دلالة العلاقة الارتباطية بين دوافع تعرض المرأة لأفلام الرعب والآثار الناجمة عنها

\begin{tabular}{|c|c|c|}
\hline مستوى الدلالة & ن & قيمة معامل الارتباط \\
\hline 0.01 & 100 & $0.38(* *)$ \\
\hline
\end{tabular}

$$
\text { * * الارتباط دال إحصائيا عند (a =0.05). }
$$

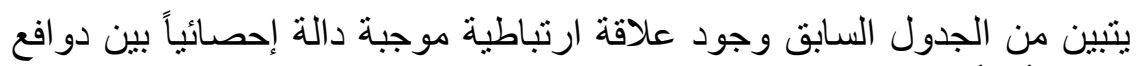

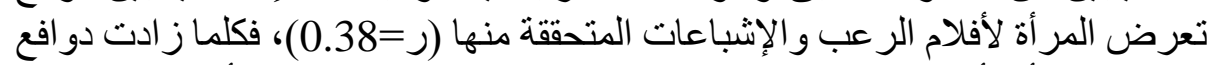

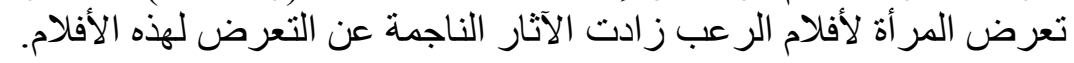

\section{تنائج الدراسة الميدانية:-}

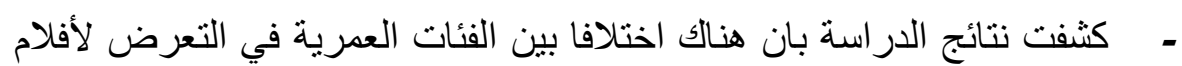

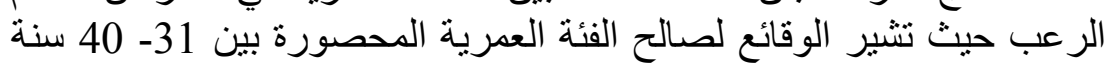

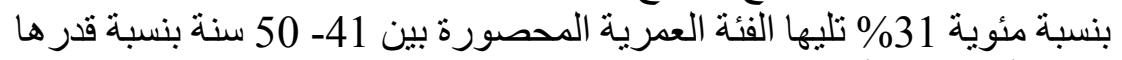

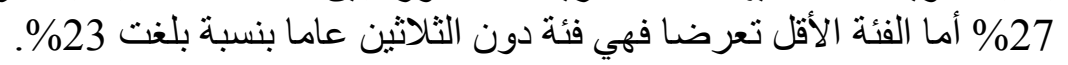

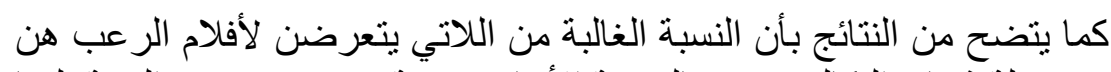

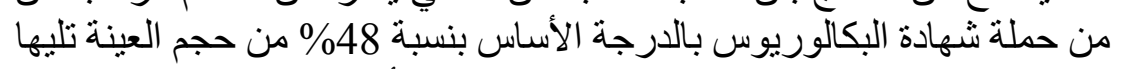

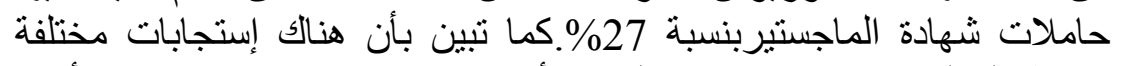

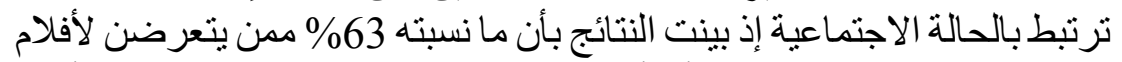

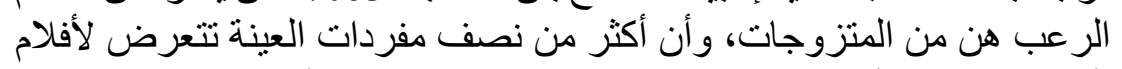

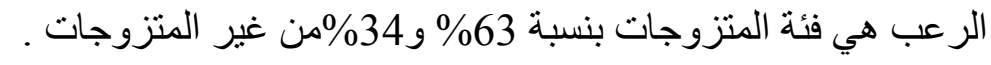

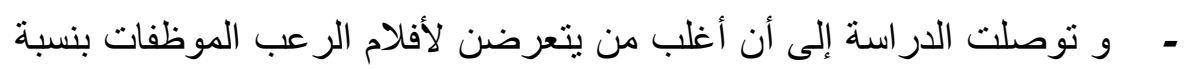
74\% و إن 53\% منهن يعملن في القطاع الحكومي.ثم القطاع الخاص ثن الخم ربات البيوت.

- كثفت الدراسة بأن الغالبية العظمى ممن بتعرضن لأفلام الرعب يحببن دائما

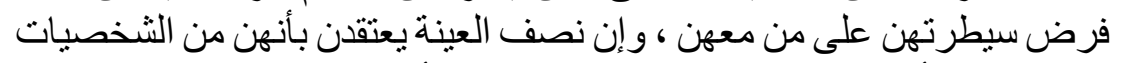

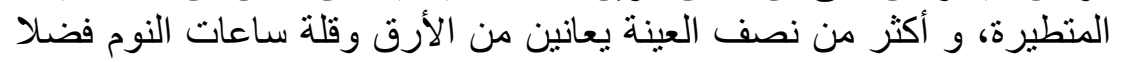


عن ثلاثة أرباع العينة بعتقدن بأن لايهن القدرة على التخيل، وأن النسبة الغالبة

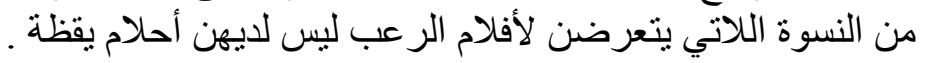

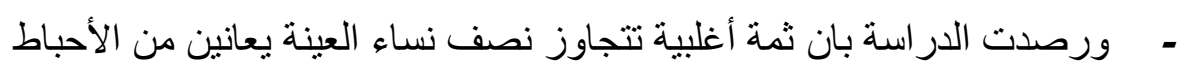

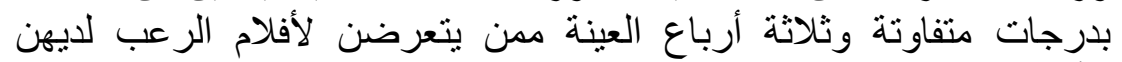

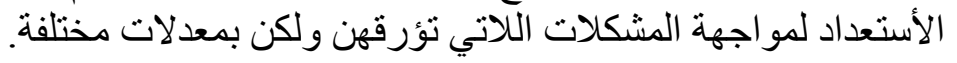

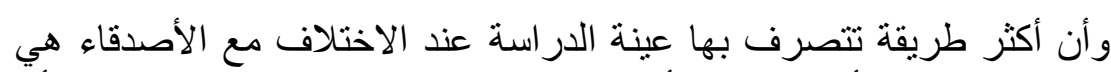

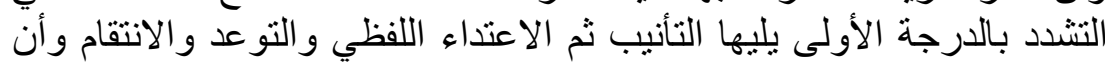

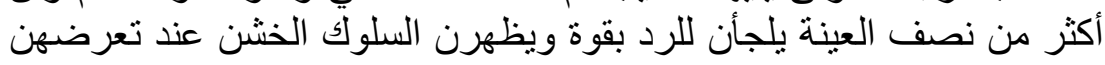

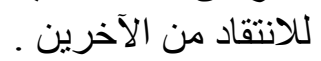

وتُظهر نتائج الدر اسة بأن أكثر الأمكنة التي تخاف منها عينة الدربة استة هي الأمكنة

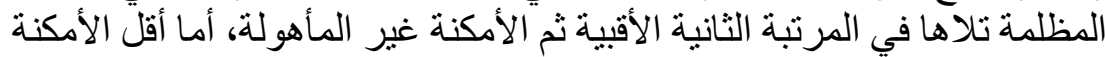

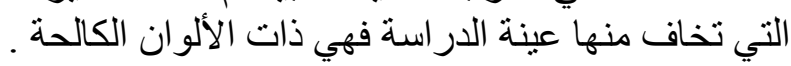

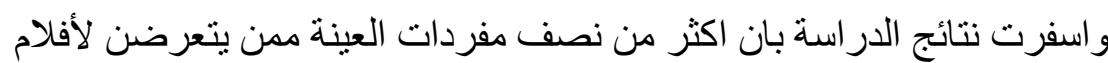

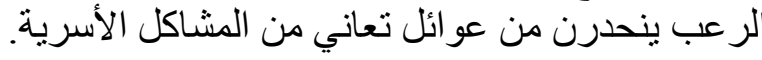

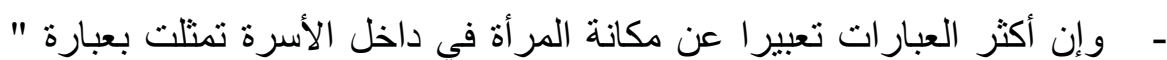

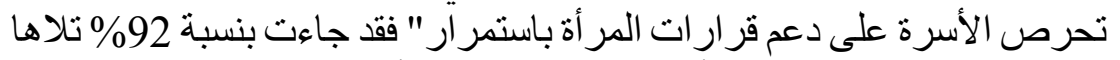

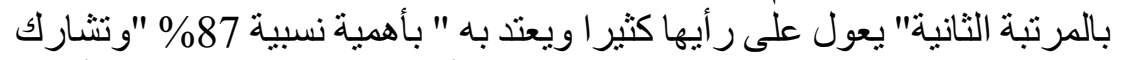

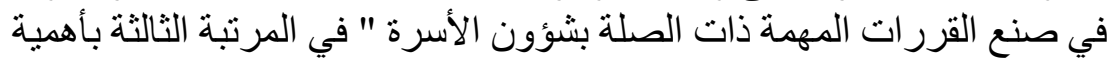

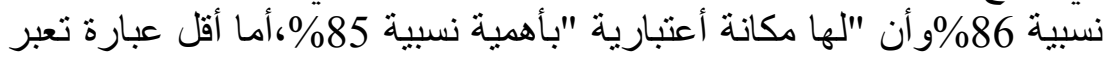

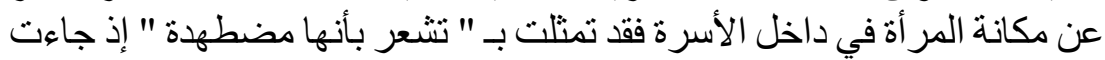

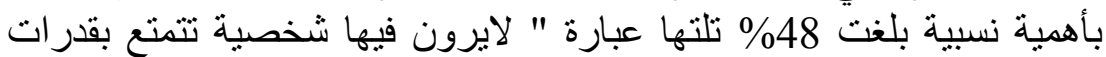

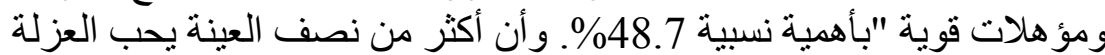
ولا يفضل الاختلاط بالآخرين .

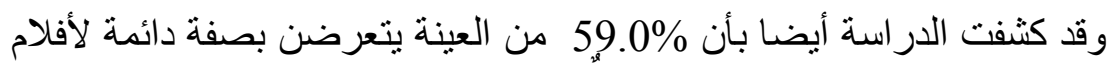

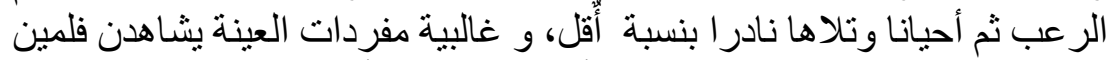

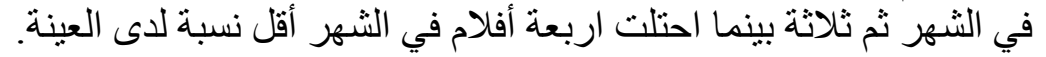

- و أن أفضل وقت لمشاهدة أفلام الرعب تمثلت في فترتي الليل و المساء و النسبة

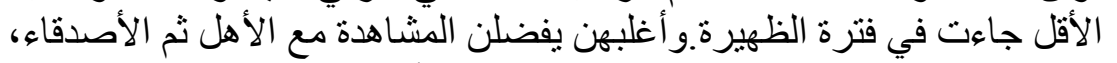

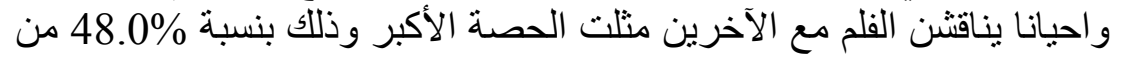

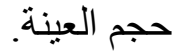

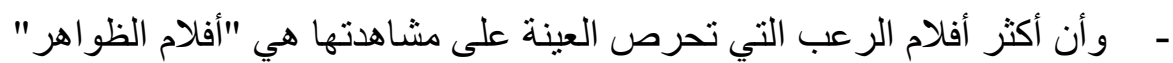

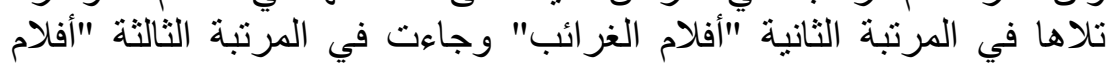


الوحوش" ثم "أفلام التقصص" فـ "أفلام المصابين بالانفصام"ءأما أقل أفلام

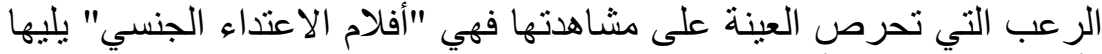

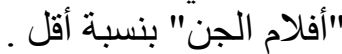

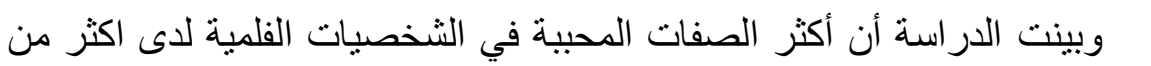

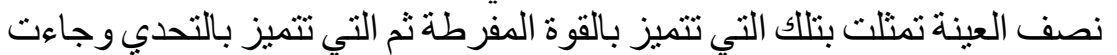

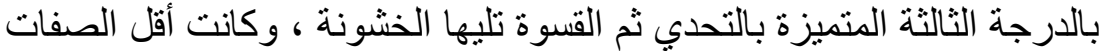

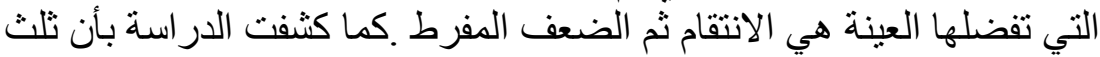

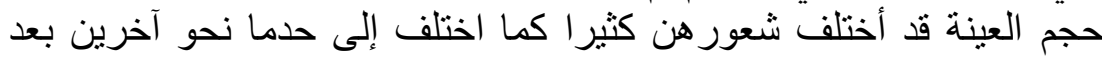

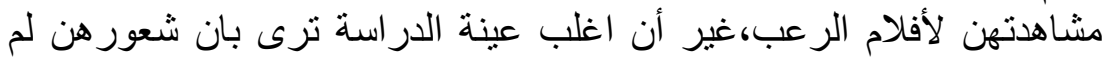

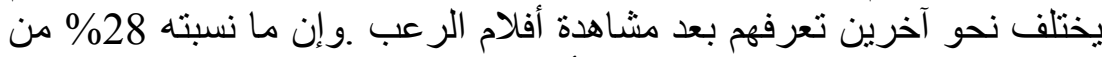

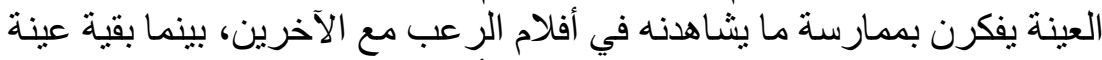
الدر اسة لا يفكرن بممارسة ما يشاهدنه في الأفلام مع الآخرين.

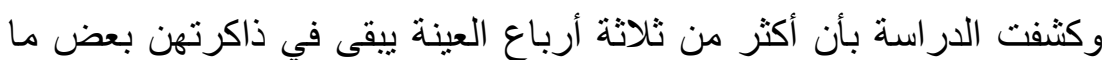

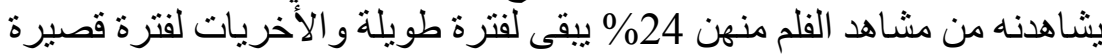

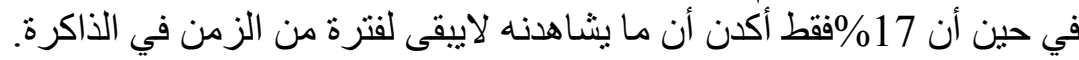

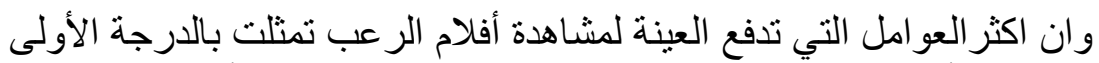

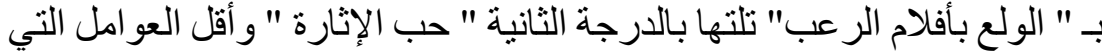

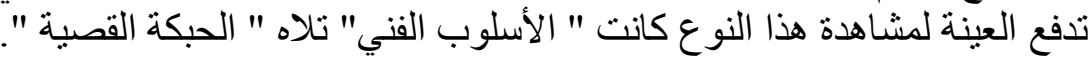

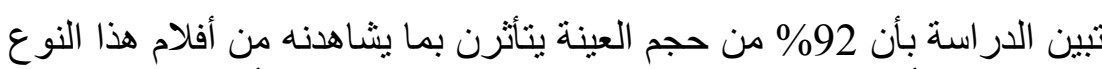

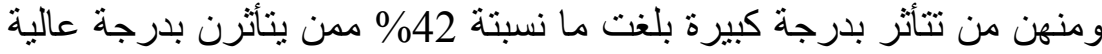

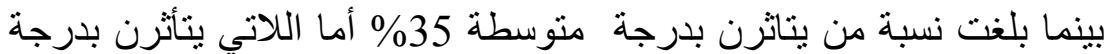

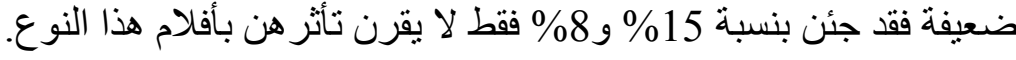

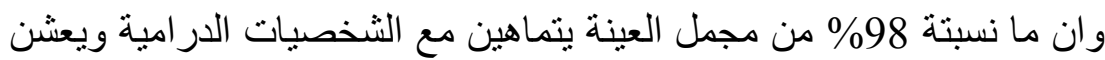

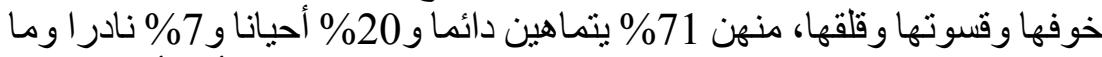
نسبته 2\% فقط لا يقرن بالتماهي مع الثخصيات الدر امية ـ و وأن تأثثيرات هذاته

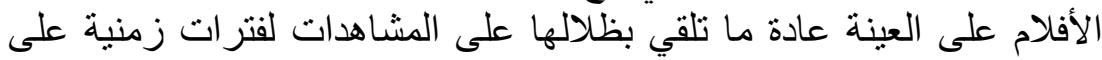
درجات متفاوتة.

و تتفق هذه النتيجة مع ما تحققت منه الدر اسة بأن الغالبية العظمى من المشاهدات

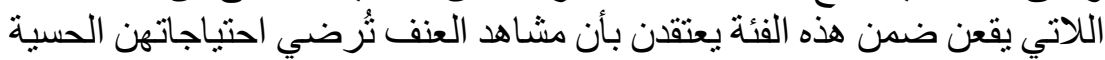

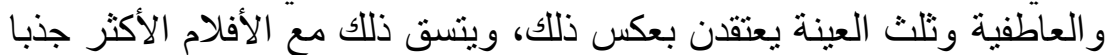

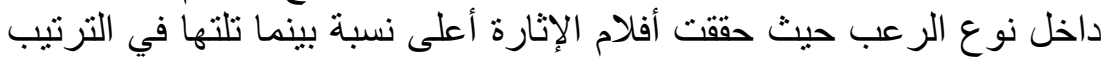


افلام الرعب الجامح ثم الصدمة فأفلام السادية، وكان أقل ما يجذب عينة الدر اسة

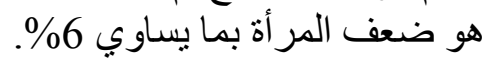

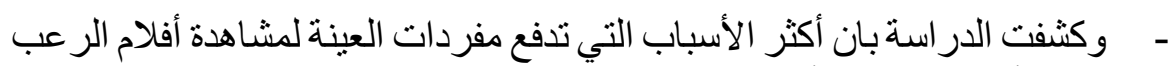

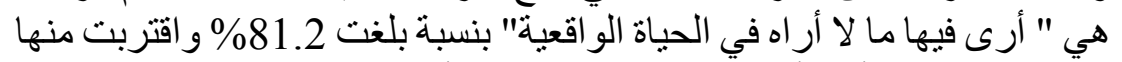

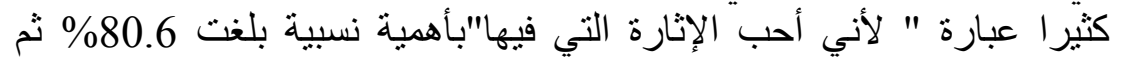

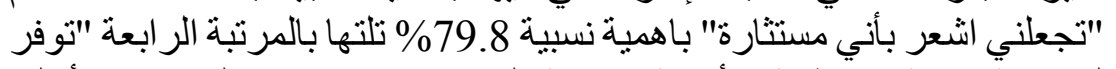

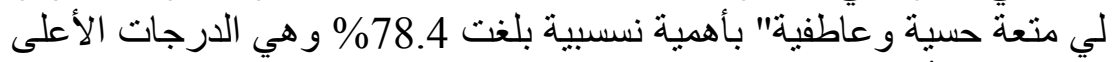

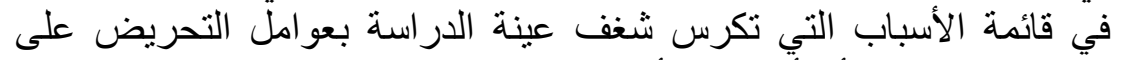

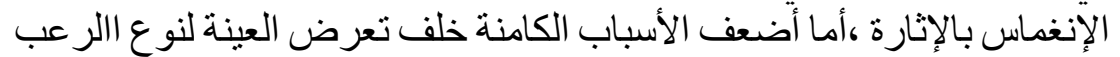

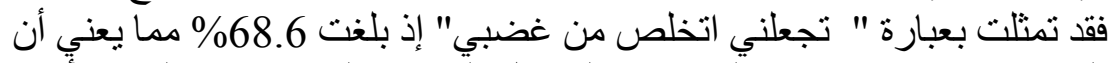
البحث عن الإثارة يتقدم على جميع العوامل امل الكامنة خلف تعرض العينة لأفَلام

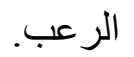

- وأن أكثر ما تشعر به عينة الدراسة بعد الأنتهاء من مشاهدة الفلم هو "أنها

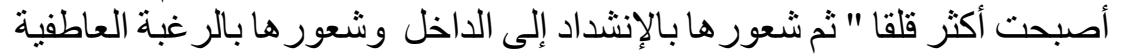

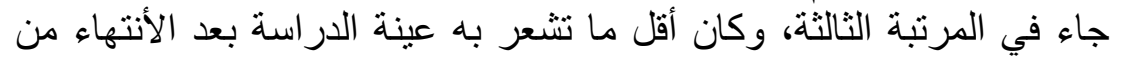

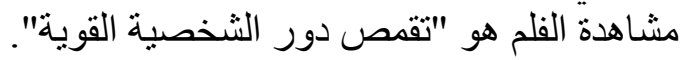

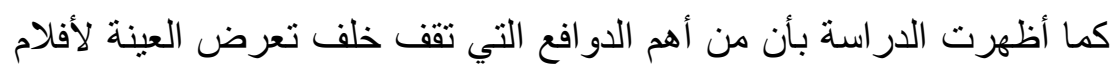

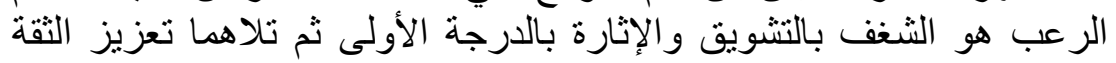

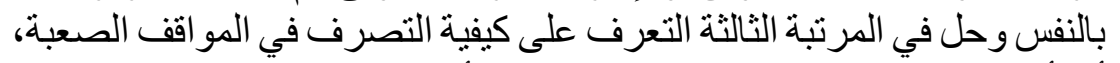

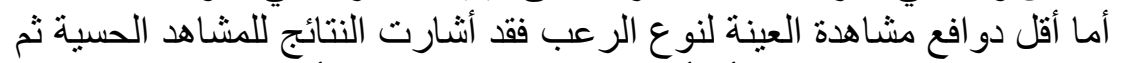

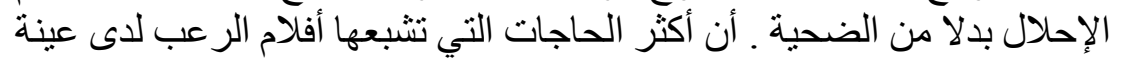

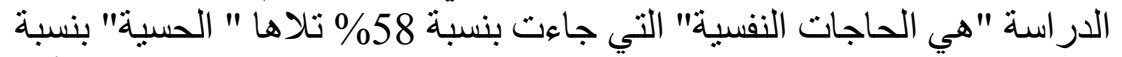

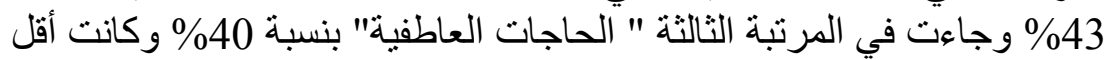

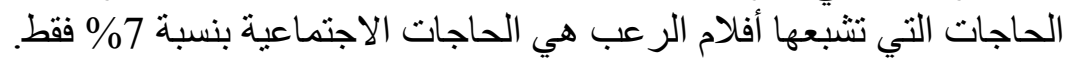

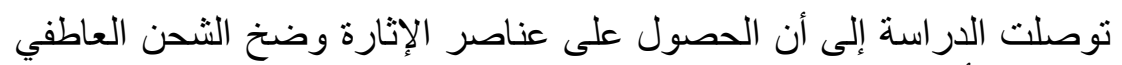

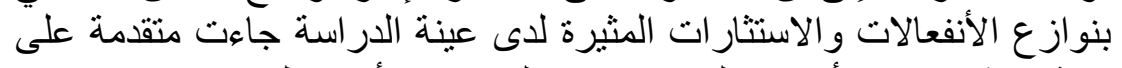

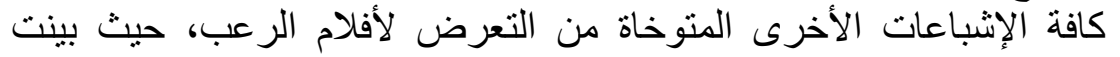

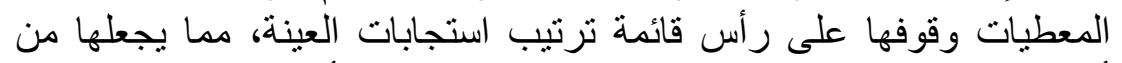

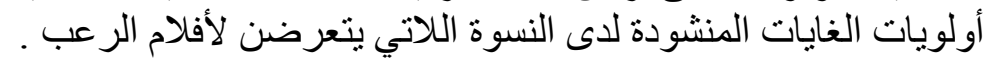

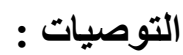

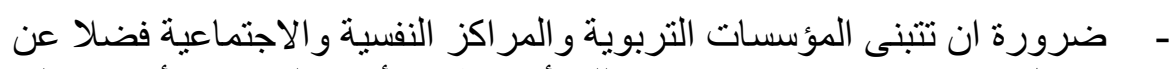

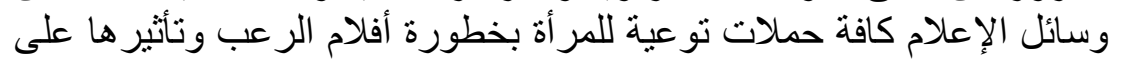




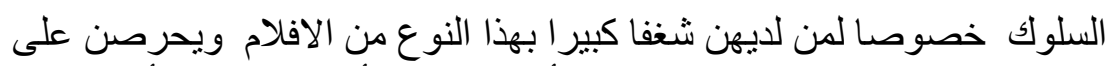

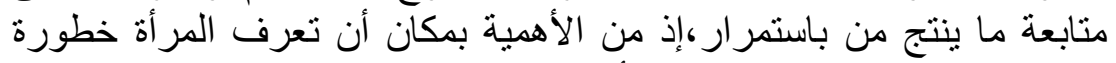

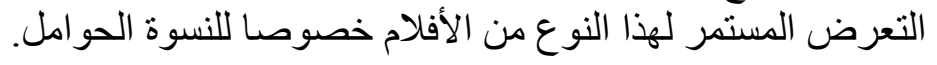

توصي الدر اسة العاملين و المختصين في المجال الإعلامي و النفسي و الاجتماعي

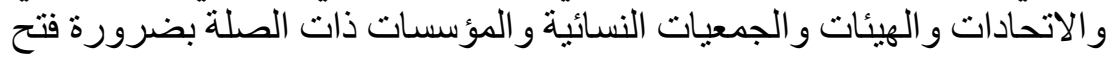

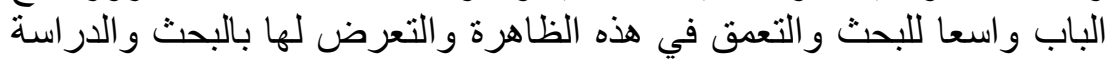

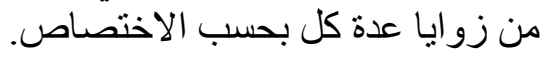

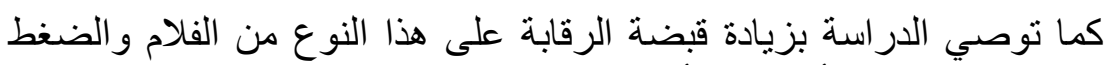

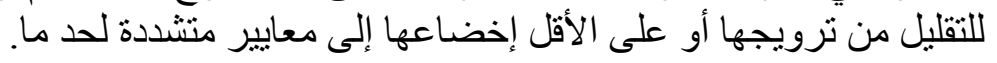

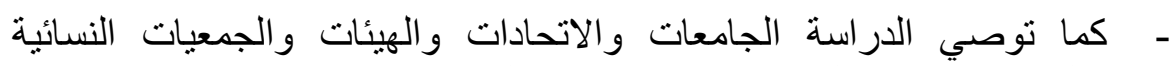

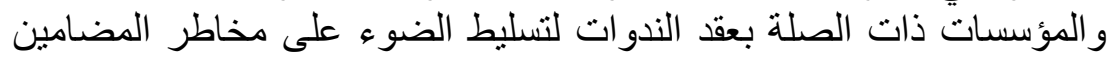

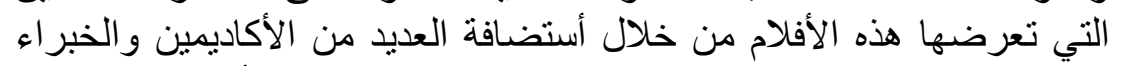

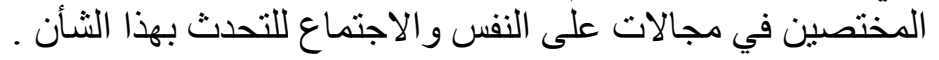




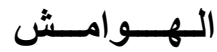

$$
\begin{aligned}
& \text { (1) جالك أومون : الصورة .ط1.ترجمة ريتا الخوري .بيروت:مركز دراسات الوحدة العربية. } \\
& \text { 2013. ص } 67 \text {. } 67 \\
& \text { (2) أندريه جلوكسمان : عالم التلفزيون بين الجمال والعنف.ط1.ترجمة وجيه سمعان عبد }
\end{aligned}
$$

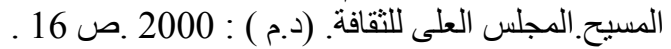

$$
\begin{aligned}
& \text { http://www.alriyadh.com/231880 (3) }
\end{aligned}
$$

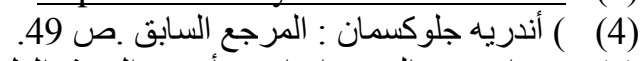

$$
\begin{aligned}
& \text { (5) مروان عبد المجيد إبراهيم .أسس البحث العبد العلمي لإعداد الرسائل الجامعية .عمان .مؤسسة }
\end{aligned}
$$

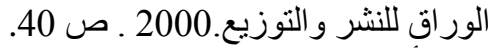

$$
\begin{aligned}
& \text { السيد أحمدمصطفى عمر: البحث الإعلامي :مفهومه وإجراعاته ومناهجه.ط1.الكويت: مكتبة }
\end{aligned}
$$

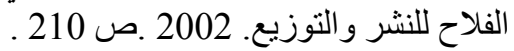

$$
\begin{aligned}
& \text { ـ محمد بن عبد العزيز الحيزان :البحوث الإعلامية :أسسها ،أساليبها،مجالاتها.الرياض :مكتبة }
\end{aligned}
$$

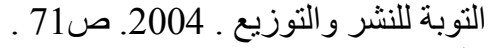

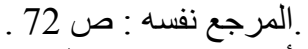

$$
\begin{aligned}
& \text { أحمد بدر : مناهج البحث والاتصال والر أي العام والاتصال الدولي.ط1.القاهرة: دارقباء للطباعة }
\end{aligned}
$$

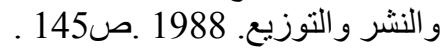

(11) - دعاء ححمد فوزى عيسى عرابى(2012 ) ) تعرض الجمهور للمواقع الإكترونية الإسلامية

و إتجاهاته نحو ممارسة تلكي المواقع لوظيفتها الاتصالية، رسالة ماجستير (غير منشورة)، جامعة الإنة

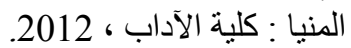

(12) در اسة وسام فاضل راضي : والبة و طالب عبدالمجيد ( 2010 ) التعرض للمسلسلات التركية.

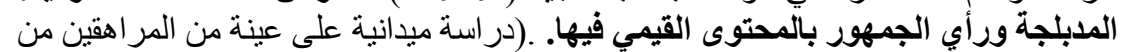

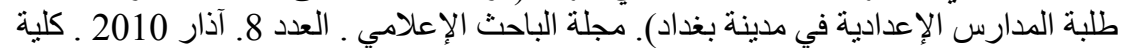

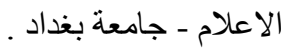

(13) عبد العزيز الطوخي : ( 2008 ) دوافع تعرض تلاميذ الإعدادي للمواد التعليمية والإثرائية من http://www.arabtexts.com/?p=591 شبكة الانترنت. متوفر على موقع :

(14) در اسة فتحية مر ابط (2001 ) : استخدامات طلاب جامعة الجزائر للقتوات الفرنسية وما تحققه

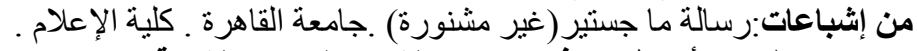

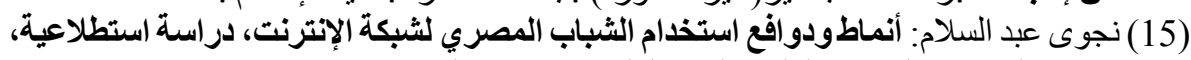

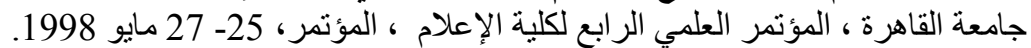

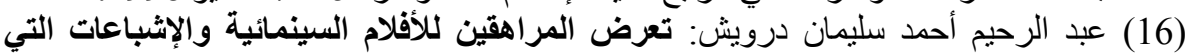

تحققها. رسالة ماجستير (غير منشورة)، جامعة القاهرة: كلية الإعلام، قسم الإذاعة، 1997 الإنة 1930

(17) Roche, Anthony: (2015)After Dracula: The 1930s Horror Film. PUBLICATION: The Irish Journal of Gothic and Horror Studies, No. 14.

(18)Ian Olney: (2013) Euro Horror: Classic European Horror Cinema in Contemporary American Culture. Indiana University Press.

(19) Sopolksy BS, Molitor F, and Luque S(2003) Sex and violence in slasher films: re-examining the assumptions, Journalism and Mass Communications Quarterly 80 (1): 28-38. 
Jack Morgan: (2002) THE BIOLOGY OF HORROR Gothic Literature (20)

and Film. Southern Illinois University Press Carbondale and Edwardsville. (21)George E. Slusser, Eric S. Rabkin :(1987) Aliens: The Anthropology of Science Fiction .Southern Illinois University Press.

(22)A.Luis Hueso Montón: Los géneros cinematograficos.Imp. De Aldecoa. Burgos.1983.P.425.

$$
\text { (23) منير البعلبكي : قاموس المورد .دار العلم للملايين .بيروت. } 2004 \text { ـص } 435 \text {. }
$$

(www.the freedictionary.com )

https://www.maajim.com/dictionary

(26) قرآن كريم : سورة آل عمران :الاية 151 .

(27)https://www.almaany.com/ar/dict/ar-ar/\%D8\%B1\%D8\%B9\%D8\%A8

(28)https://en.wikipedia.org/wiki/No\%C3\%AB1_Carroll

(29)Noël Carroll : The Philosophy of Horror, or Paradoxes of the Heart,

New York, Routledge, 1990.P.96.

(30).www.startimes.com/?t=30537956

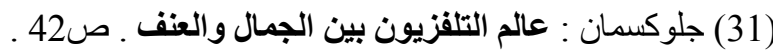

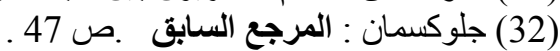

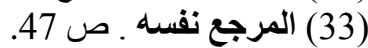

(34)Bogart.L. The Age of Television ,Frederick Unger Publishing Co.New York,1956.pp 384 .

(35) .أحمد خالد نوفيق وسند ر اثند دخيل:موسوعة الظلام .ط1.الكويت:.إصدارات دايموند،2009،

$$
\text { ص10 } 11 \text {. } 11 \text {. }
$$

(36)Noël Carroll : The Philosophy of Horror, or Paradoxes of the Heart, New York, Routledge, 1990.P.17.

(37):OP.Cit .P.430

A.Luis Hueso

Montón

(38) Ibid.P.430.

Montón

(39)Molina Foix,J,A: Horrosocope,Mitos basicos del cline de terror.

Madrid .Nostromo.1973.P.37.

(40)Steiger,Bral: (1975) Master Movie Mononsters.ChicagoP.58

(41)Barber,Dulan: (1975) The Horrific world of monsters.

Londers.Cavendish.P.125.

(42):OP.Cit .P.430

A.Luis Hueso

Montón

(43) www.elfagr.org

(44) w.arageek.com

(45)https://www.arageek.com/2014/12/11/top-10-horror-films-in-2014.html

(46) ححم منير حجاب : نظريات الاتصال .ط1.القاهرة:دار الفجر للنشر والتوزيع ـ 2010 ـ ص 298 
(47) المرجع السابق : ص 298 . .

(48) حسن عماد مكاوي وليلى السيد : الاتصال ونظرياته المعاصرة ـ ـ57. القاهرة:الدار المصرية

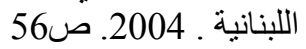

565) (49) المرجع نفسها :

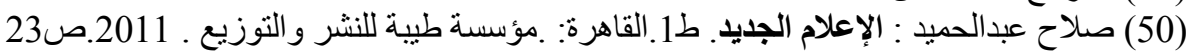

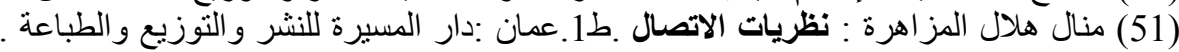

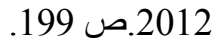

(52) حمح عبد الحميد : نظريات الإعلام واتجاهات التأثير.ط1.القاهرة: عالم الكتب ـ 2000 ـ . .

210 . 210 297

(54) ) فرج الكامل : الاتصال ونظريات الرأي العام - تصميمها وإجراؤها وتحليلها.ط1.مصر: .دار

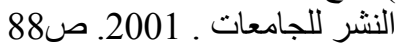
(55) حسن عماد مكاوي وليلى السيد : المرجع السابق ـ ص 20016 . 